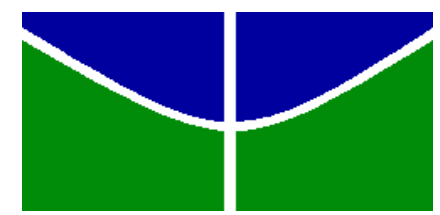

UNIVERSIDADE DE BRASÍLIA - UnB

FACULDADE DE EDUCAÇÃO - FE

PROGRAMA DE PÓS-GRADUAÇÃO EM EDUCAÇÃO - PPGE

PERCEPÇÕES DE PROFESSORES DA REDE PÚBLICA SOBRE O TABLET EDUCACIONAL: UM ESTUDO DE CASO NO DF

ADRIANA ALVES DE MOURA

BRASÍLIA

2015 
ADRIANA ALVES DE MOURA

PERCEPÇÕES DE PROFESSORES DA REDE PÚBLICA SOBRE O TABLET EDUCACIONAL: UM ESTUDO DE CASO NO DF

Dissertação apresentado à Comissão Examinadora do Curso de Pós-Graduação da Faculdade de Educação da Universidade de Brasília como requisito parcial para a obtenção do título de Mestre em Educação, sob a orientação da Professora Doutora Vânia Lúcia Quintão Carneiro.

BRASÍLIA

2015 
Ficha catalográfica elaborada automaticamente, com os dados fornecidos pelo(a) autor(a)

Moura, Adriana Alves de
PERCEPÇÕES DE PROFESSORES DA REDE PÚBLICA SOBRE o
TABLET EDUCACIONAL: UM ESTUDO DE CASO NO DF /
Adriana Alves de Moura; orientador Vânia Lúcia
Quintão Carneiro. - - Brasília, 2015.
150 p.
Dissertação (Mestrado - Mestrado em Educação) --
Universidade de Brasilia, 2015.
1. Tecnologias Digitais de Informação e
Comunicação. 2. Educação. 3. Tablet Educacional. 4.
Percepção dos professores. I. Carneiro, Vânia Lúcia
Ouintão, orient. II. Título.




\title{
PERCEPÇÕES DE PROFESSORES DA REDE PÚBLICA SOBRE O TABLET EDUCACIONAL: UM ESTUDO DE CASO NO DF
}

\begin{abstract}
ADRIANA ALVES DE MOURA
Dissertação apresentado à Comissão Examinadora do Curso de Pós-Graduação da Faculdade de Educação da Universidade de Brasília como requisito parcial para a obtenção do título de Mestre em Educação, defendida em 17 de Abril de 2015. Banca Examinadora constituída pelos professores:
\end{abstract}

Orientadora: Prof. a . Drª . Vânia Lúcia Quintão Carneiro

Universidade de Brasília - Faculdade de Educação

Membro: Prof. ${ }^{a}$. Dra ${ }^{\mathrm{a}}$. Cláudia Márcia Lyra Pato

Universidade de Brasília - Faculdade de Educação

Membro: Prof. a . Dr ${ }^{\mathrm{a}}$. M ${ }^{\mathrm{a}}$ Elisabette Brisola Brito Prado Universidade Bandeirante de São Paulo - Programa de Pós-Graduação

Suplente: Prof. ${ }^{\text {a }}$ Dr ${ }^{\mathrm{a}}$. Laura Maria Coutinho

Universidade de Brasília - Faculdade de Educação 


\section{DEDICATÓRIA}

A toda a minha família que vislumbra em sua primeira mestra a representação do esforço, dedicação e superação de gerações.

Ao meu pai e in memoriam, minha mãe, guerreiros que na humilde formação mostraram aos filhos o valor de uma educação para a formação do indivíduo como forma de construção de um mundo melhor.

Ao meu esposo, companheiro de todas as horas, que me incentivou nos momentos mais difíceis. Amor e gratidão são palavras que se associam ao meu sentimento a esse homem especial em minha vida.

Aos meus filhos, presentes de Deus, que foram compreensivos pela minha ausência em muitos momentos e mesmo assim, se mostrarem presentes e incentivadores para a conclusão dessa etapa.

Aos meus irmãos, e também a Augusta Márcia, nos quais tenho como exemplos a força e garra para prosseguir e não desistir apesar dos percalços.

Aos meus amigos que compreenderam minhas ausências em muitos momentos e me incentivavam com palavras de ânimo e felicitações por esta fase nova e desafiante em minha vida.

A todos aqueles pesquisadores ou não que se sentiram motivados a conhecer sobre o tema da pesquisa.

A todos que vislumbram um país mais crítico, autônomo e justo através da educação desse povo. 


\section{AGRADECIMENTOS}

Ao me aventurar novamente nos estudos acadêmicos e chegar à conclusão dessa dissertação posso dizer que a jornada foi longa e muitas vezes exaustiva. Mas foi possível devido ao auxílio de muitas mãos e este momento é o mais apropriado para eu agradecer a cada uma.

Agradeço, primeiramente, ao Senhor, meu Deus por sempre me guiar e conduzir os meus caminhos a mais uma conquista.

À minha família, por estar sempre presente me apoiando e incentivando em todas as etapas de minha vida.

À minha orientadora, Prof. ${ }^{a}$ Dra. Vânia Quintão, pelos encontros em que impulsionaram vários insights que conduziram as minhas ideias e opiniões acerca do estudo da pesquisa, bem como, me auxiliaram na supervisão e checagem dos fatos e dados coletados. Todo esse carinho e atenção resultaram nesta dissertação e na minha formação como pesquisadora.

Às professoras Cláudia Pato, Maria Elisabette Prado, Laura Coutinho por terem aceitado o convite para compor a banca examinadora.

A todos os professores do PPGE que contribuíram em suas disciplinas acendendo campos de conhecimento e que engrandeceram o meu projeto de pesquisa. Em especial, à Prof. ${ }^{a}$ Dra. Cláudia Pato por instigar-me a aventurar no método misto realizado nesta dissertação e ainda, por me apoiar nas etapas quantitativas percorridas.

A todos os amigos que pude conhecer e conviver durante esses anos de mestrado, no ir e vir de atividades na Faculdade de Educação. E auxiliaram-me nesta caminhada.

À amiga Ingrid Neto, conquistada durante minhas análises quantitativas, por seu fundamental apoio e auxílio com o software SPSS. 
Às amigas: Cleia Nogueira por ter me incentivado e impulsionado meu ingresso na Universidade, bem como trilhar esse caminho ao meu lado; Geusiane Miranda por ser um espelho para o meu ingresso no mestrado, futura doutora; e outra companheira de mestrado, Sandra Campêlo por me auxiliar no refino das palavras, das frases, dos pensamentos aqui expressos. Às três pelas inúmeras horas de conversas nas quais críticas, desabafos e boas risadas me fortificavam a ir avante.

À amiga Mabel Pereira pelo carinho e atenção demonstrada pelos seus dotes artesanais e que deram um charme a mais a apresentação dessa dissertação.

À Secretaria de Educação do Distrito Federal, por me conceder o afastamento remunerado e poder me dedicar inteiramente neste estudo.

Aos professores da SEDF, participantes dessa pesquisa, que dedicaram parte do seu tempo nos questionários e na entrevista. A atenção e interesse de todos foram fundamentais para a construção do conhecimento na área de Educação Tecnologias e Comunicação, sem os quais essa pesquisa não seria possível.

A todos aqueles que não foram mencionados por escrito neste espaço, mas estão presentes nas minhas lembranças como amigos e familiares.

Enfim, meus sinceros agradecimentos! 
"Pesquiso para constatar, constatando, intervenho, intervindo educo e me educo. Pesquiso para conhecer o que ainda não conheço e comunicar ou anunciar a novidade.". 


\section{RESUMO}

Esta dissertação resulta de uma pesquisa que teve como objetivo analisar as percepções e a receptividade dos professores de ensino da rede pública do Distrito Federal, especificamente da Cidade Ceilândia, sobre o Tablet Educacional, por meio dos níveis de aceitação desse recurso como ferramenta pedagógica. O recurso tecnológico em evidência nesta pesquisa faz parte do projeto Educação Digital proposto pelo MEC aos professores do ensino médio de todo o país. Durante essa investigação, meu aporte teórico pautou-se na dicotomia existente perante a cultura de massa às tecnologias mencionada por ECO (1970); no homem tecnológico, nas mudanças advindas dessas tecnologias e na evolução humana propostas por FERKISS (1976); na transformação do mundo ditada pela informação advinda pela tecnologia e pela internet unindo todos numa sociedade em rede com problemas, anseios e expectativas comuns explicitados por CASTELLS (2011); na dicotomia entre nativos e imigrantes digitais provenientes do avanço tecnológico apresentada com PRENSKY (2006); nas diversas formas de aliar a tecnologia à aprendizagem e à escola defendidas por PAPERT (2008); na cultura da convergência propulsada pelas novas mídias e as transformações decorrentes explicitadas por JENKINS (2009); na percepção, nos sentidos e no conhecimento abordado por JORGE (2011), entre outros. O presente estudo expressa o olhar do professor acerca das Tecnologias Digitais de Informação e Comunicação (TDIC), especificamente, o Tablet Educacional, em seu meio, através do modelo proposto pela Teoria Unificada de Aceitação e Uso da Tecnologia designada pela sigla UTAUT (Unified Theory of Acceptance and Use of Technology) desenvolvida por Venkatesh et al. (2003), no intuito de expandir o horizonte do docente na busca de sua identidade nesta sociedade digital. A metodologia adotada refere-se ao estudo de caso e por visar um aprofundamento na questão levantada, as abordagens quantitativas e qualitativas foram necessárias, o que caracteriza a utilização do método misto. Foram utilizados questionário e entrevista semiestruturada e os resultados obtidos exibem um professor crítico e autônomo em relação ao Tablet Educacional inserido no contexto educacional. No entanto, expõe um ser indeciso quanto à relevância dessa tecnologia no processo ensino-aprendizagem. Essa controvérsia reflete uma receptividade a esse recurso tecnológico, mas com pouco nível de aceitação ao mesmo. Quanto ao modelo proposto, ele mostrou-se oportuno e valioso ao estudo em questão. A partir dos dados coletados pode-se validar os quatro constructos determinantes da teoria UTAUT: Expectativa 
de Desempenho/Perfomance, Expectativa de Esforço, Influência Social e Condições Facilitadoras. As condições facilitadoras apresentaram impactantes diretas à intenção de uso ao Tablet Educacional. A pesquisa significa uma contribuição para trabalhos futuros que busquem compreender a pertinência e o valor da tecnologia no contexto educacional.

Palavras-chave: Tecnologias Digitais de Informação e Comunicação. Tablet Educacional. Educação. Percepção dos professores. 


\begin{abstract}
\end{abstract}
This research is a result of a study which aims the perception and receptiveness of teachers who work at the public schools at Distrito Federal. The school chosen for the development of this research is located at Ceilandia and the main issue is the Educational Tablet as a pedagogical tool of acceptance on the part of those educators. The focus on this research is part of a the Digital Educational Project implemented by the Ministry of Education in Brazil (MEC) which is concerned about all high school teachers all over the country.During this investigation, the theoretical framework was based on the dichotomy existing into the mass culture aspects mentioned by ECO (1970); on the technological human being related to the changes showed during the usage of such new technologies as well as the human evolution proposed by FERKISS (1986). This paper also considered the theories which postulates issues considering the world transformation as a consequence of the usage of those technologies and the considerations that can be withdrawn from studies of CASTELS (2011). Another point to be considered is the dichotomy between the digital immigrants and non immigrants according to PRENSKY (2006) and the alliance between technology and learning competences PAPERT (2008).The study also considered the postulations of JENKINS (2009) in terms of explicit changes derived from technology and the studies of JORGE (2011) in relation to senses and perceptions towards the science of knowledge. The objective of this research is to express the opinion of those teachers in relation to Digital Technologies of Information and Communication (DTIC) and through the model known as UTAUT (Unified theory of Acceptance and Use of Technology) which was developed by Venkatesh et al. (2003) which objective was to expand the educator horizon as to place his/her identity into the digital society. This study is in line with a case study once its main objective is to deepen the questions mentioned above. Both the qualitative and quantitative methods were used, so it had supported on demonstrate the results. Questionnaires and interviews semi-structure were used for data collection and the results have shown that the educators place themselves into a critical and autonomous in relation to the usage of the Digital Tablet. Nonetheless, it was observed that indecision is a factor that is continues present when related to the importance of technology in the process of learning and acquisition. Such controversy reflects little or almost non- acceptance to the technological tool. Regarding the proposed model, the study has show its importance for the educators practice nowadays. Regarding the UTAUT method, 
four constructs were validated: a) Competence/Performance; b) Expectation of Effortless; c) Social Influence and d) Facilitating Conditions Finally, the research has shown that the facilitating conditions led to the usage of the Tablet; for this reason, the research implies future contributions for future studies which is focused into the value of technology in the educational context.

Keywords: Digital Technologies of Information and Communication, Educational Tablet. Education, Perception of teachers. 
Figura 1 - O Tablet Educacional 31

Figura 2- Mapa Conceitual da Teoria Unificada de Aceitação e Uso da Tecnologia -UTAUT-. 49

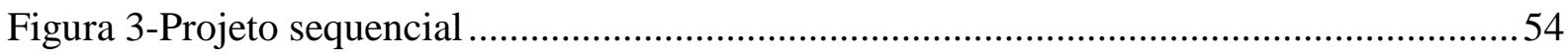

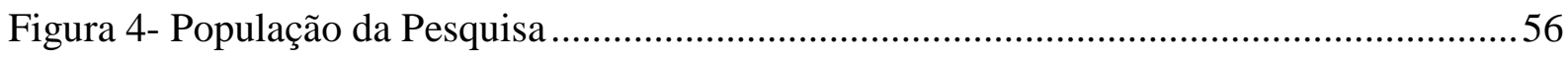

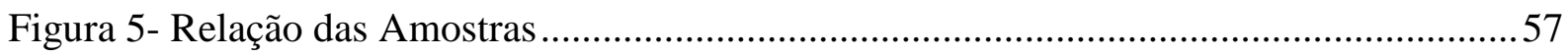

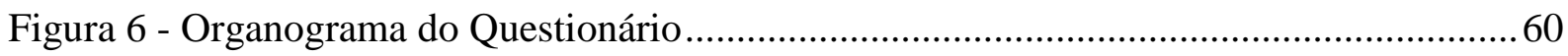

Figura 7- Esquema da estrutura do questionário - Versão Final............................................ 78

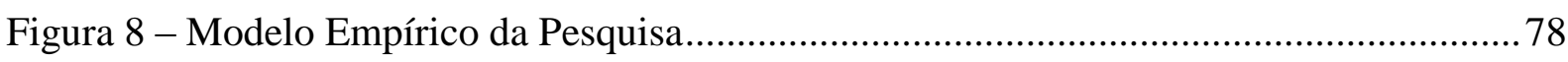

Figura 9 - Modelo 1 das equações estruturais da amostra global ......................................... 80

Figura 10- Modelo 2 das equações estruturais da amostra global......................................... 81

Figura 11 - Visualização das Categorias (Nós) da pesquisa no Nvivo.................................... 94

Figura 12 - Nuvens de Palavras mais citadas na pesquisa qualitativa no Nvivo.....................95

Figura 13 - Análise de Cluster obtida pelo Nvivo ...............................................................97

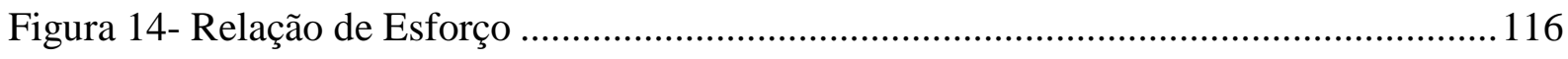


Quadro 1 - Especificações Técnicas do Recurso Tecnológico - Tablet ................................... 32

Quadro 2 - Modelos de uso e aceitação das tecnologias ....................................................... 45

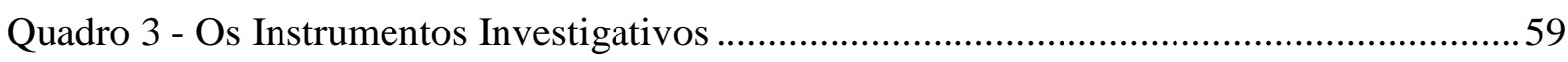

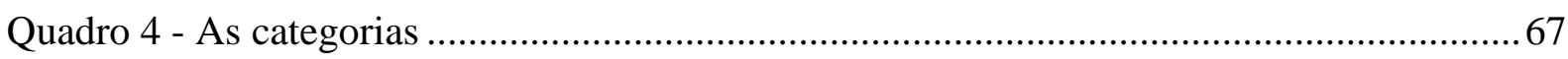

Quadro 5 - Condições para o uso do Tablet no contexto da pesquisa ................................... 105 


\section{LISTA DE TABELAS}

Tabela 1- E-mails enviados na versão preliminar do questionário 63

Tabela 2 - E-mails enviados na versão final do questionário................................................. 70

Tabela 3 - Matriz de Componente Rotativa ............................................................................. 77

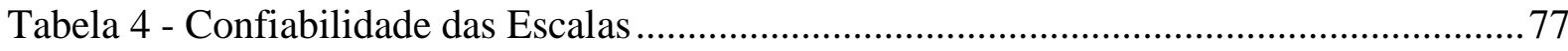

Tabela 5 - A decisão quanto a utilizar ou não o Tablet ........................................................... 82

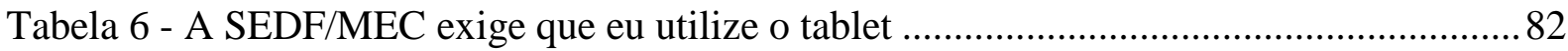

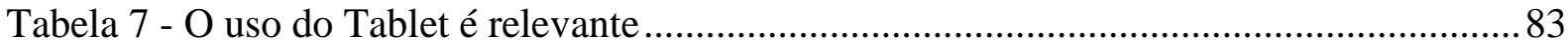

Tabela 8 - Estatísticas do constructo: Expectativa de Desempenho......................................... 84

Tabela 9 - Estatísticas do Fator: Intenção de uso ...................................................................... 90 


\section{LISTA DE GRÁFICOS}

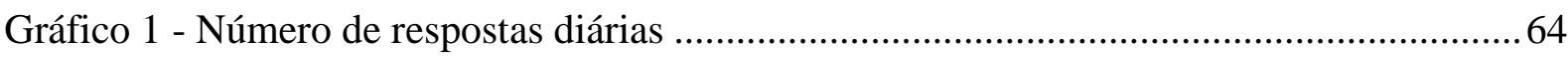

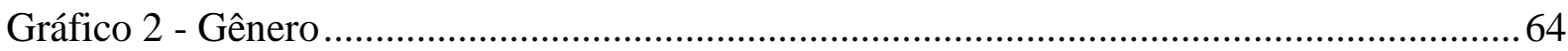

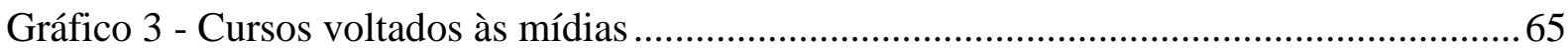

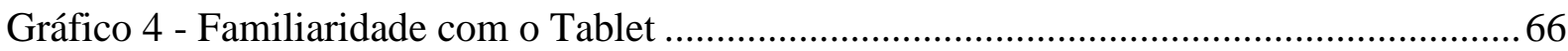

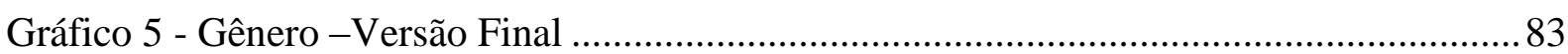

Gráfico 6 - Qual o seu grau de familiaridade com o recurso tecnológico- Tablet e seus

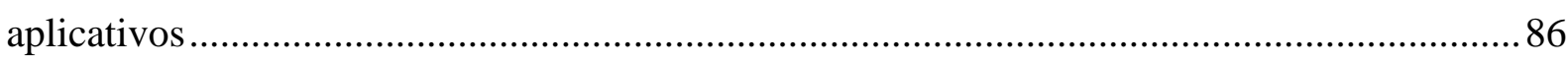

Gráfico 7 - Participou de outros cursos voltados às mídias? ................................................. 86

Gráfico 8 - Eu acho que o Tablet é fácil de usar em comparação com o computador pessoal

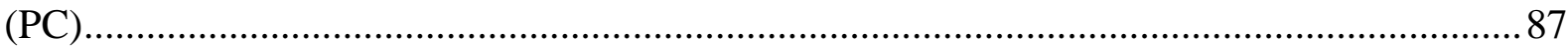

Gráfico 9 - A publicidade em geral me incentiva a usar o tablet no meu trabalho ...................88

Gráfico 10 - Utilizando o Tablet no meu trabalho, meus alunos me virão como uma pessoa

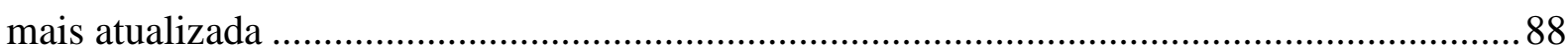

Gráfico 11 - Ajuste do Tablet Educacional à forma de ensino-aprendizagem ........................92 


\section{LISTA DE SIGLAS}

BNDES Banco Nacional de Desenvolvimento Econômico e Social

DF Distrito Federal

Eape $\quad$ Escola de Aperfeiçoamento dos Profissionais da Educação

Gead Gerência de Educação a Distância

MEC Ministério da Educação

MM Modelo Motivacional

MPCU Modelo de Utilização do PC

NTE Núcleo de Tecnologia Educacional

PBLE Programa Banda Larga nas Escolas

Proinfo Programa Nacional de Tecnologia Educacional

ProInfo Programa Nacional de Formação Continuada em Tecnologia Educacional

PROUCA Programa Um Computador por Aluno

SEDF Secretaria de Estado de Educação do Distrito Federal

SI Sistema de Informação

TAM Modelo de Aceitação da Tecnologia

TAM-TPB Modelo Combinado

TDIC Tecnologias Digitais de Informação e Comunicação

TIC Tecnologias de Informação e Comunicação

TPB Teoria de Comportamento Planejado

TRA Teoria da Ação Racional

UAB Universidade Aberta do Brasil

UCA Um Computador por Aluno

UNESCO Organização das Nações Unidas para a Educação, a Ciência e a Cultura

UTAUT Teoria Unificada de Aceitação e Uso da Tecnologia 


\section{SUMÁRIO}

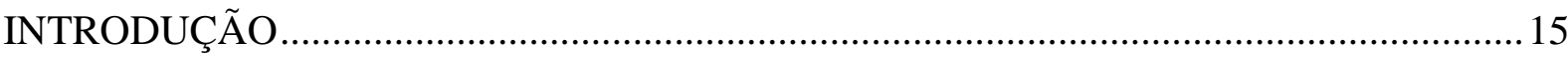

CAPÍTULO I - UM SOBREVOO NOS PROGRAMAS GOVERNAMENTAIS

REFERENTES ÀS TDIC NO CONTEXTO EDUCACIONAL ............................................21

1.1 Os programas governamentais voltados para as TDIC ............................................... 21

1.2 O Projeto Educação Digital, o Tablet Educacional e suas transformações .....................26

1.2.1 O Tablet Educacional distribuído pelo MEC............................................................... 31

1.2.2 O Curso de Formação oficial proposto para o uso do Tablet ....................................... 34

CAPÍTULO II - PERCEPÇÕES, PROFESSORES E RECURSOS TECNOLÓGICOS ......... 37

CAPÍTULO III - A RECEPTIVIDADE AOS RECURSOS TECNOLÓGICOS....................41

CAPÍTULO IV - TEORIA UNIFICADA DE ACEITAÇÃO E USO DA TECNOLOGIA

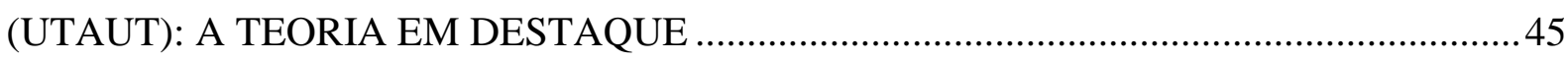

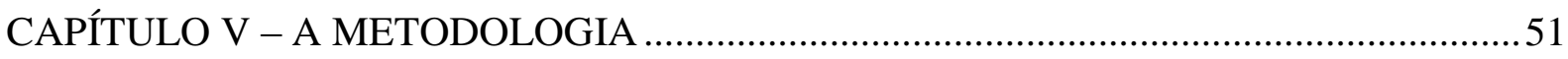

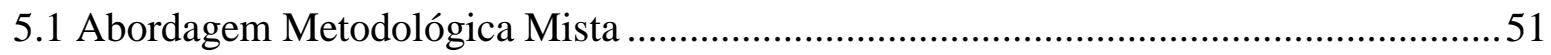

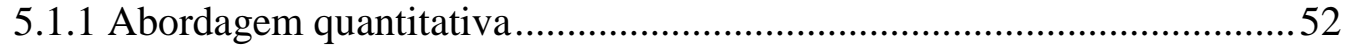

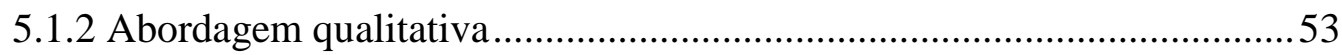

5.1.3 Estratégia Explanatória Sequencial...................................................53

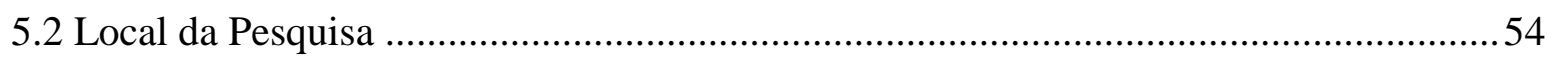

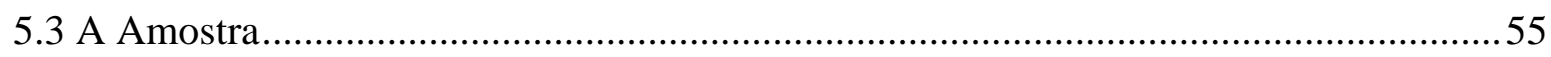

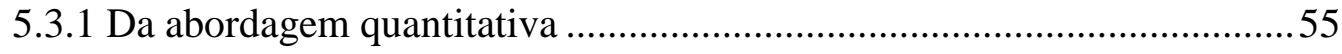

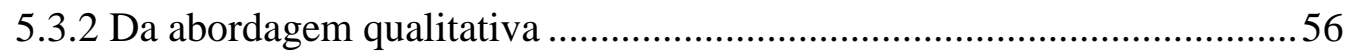

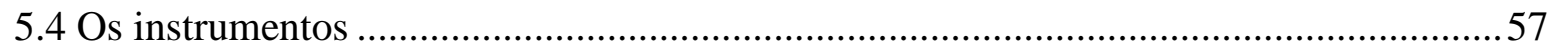

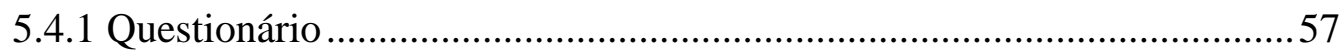

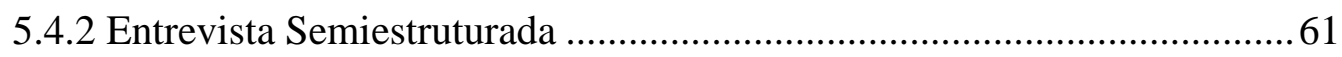

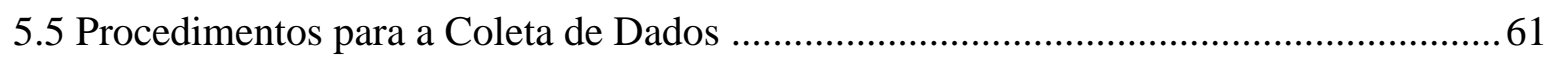

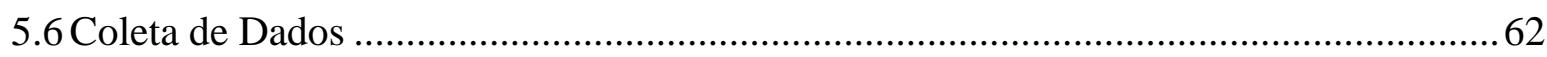

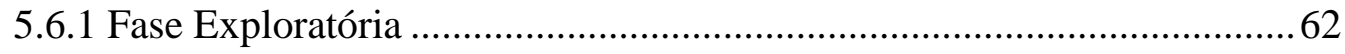

5.6.2 Fase da coleta dos dados quantitativos .................................................68

5.6.3 Fase da coleta dos dados qualitativos ................................................ 70

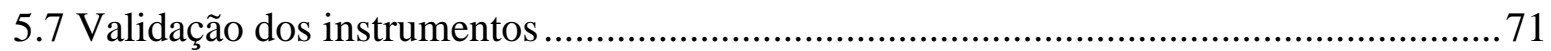

5.8 Estratégias e Instrumentos de Análise ............................................................... 71 
6.1 O questionário e os resultados quantitativos da teoria UTAUT ................................. 74

6.1.1 Confiabilidade do instrumento....................................................... 77

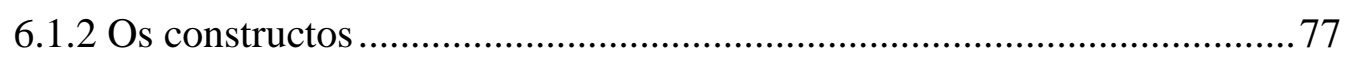

6.1.2.1 Constructo Voluntariedade de Uso ........................................8 81

6.1.2.2 Constructo Expectativa de Desempenho/Performance ............ 84

6.1.2.3 Constructo Expectativa de Esforço ......................................... 85

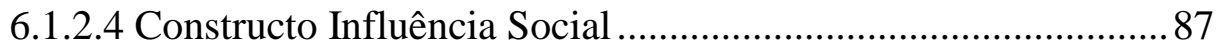

6.1.2.5 Constructo Condições Facilitadoras ....................................... 89

6.1.2.6 Constructo Intenção de Uso ................................................. 90

6.2 A entrevista e os resultados qualitativos da teoria UTAUT ........................................ 92

6.2.1 Apresentação da estrutura do instrumento pelo Nvivo ........................... 93

6.2.1.1 Análise horizontal ou transversal .........................................95

6.2.1.2 Análise Cluster ........................................................................96

6.2.2 As categorias e os constructos da teoria UTAUT .................................99

6.2.2.1 Condições Facilitadoras ............................................................ 99

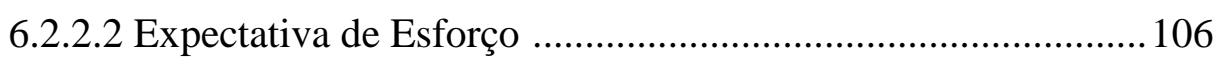

6.2.2.3 Expectativa de Desempenho/Performance ............................ 108

6.2.2.4 Influência Social ................................................................ 110

CAPÍTULO VII - DISCUSSÃO DOS RESULTADOS.................................................... 113

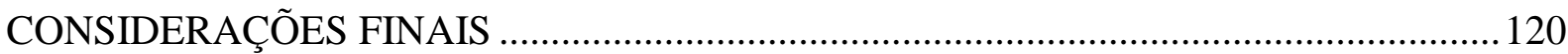

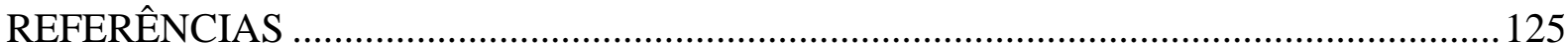

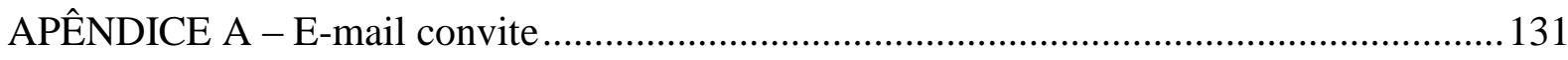

APÊNDICE B - Quadro Comparativo dos itens da Teoria UTAUT com os da nossa Pesquisa

APÊNDICE C- Questionário - Versão Final .................................................................... 136

APÊNDICE D - Termo de consentimento Livre e Esclarecido da Entrevista Semiestruturada

APÊNDICE E - Protocolo da Entrevista Semiestruturada 143 


\section{INTRODUÇÃO}

A presente dissertação exprime as análises acerca das percepções e a receptividade do professor ao recurso tecnológico, o Tablet Educacional, como ferramenta pedagógica.

A formação da percepção apesar de ser um ato solitário do indivíduo, direta ou indiretamente envolve outros ao seu redor, fatores, objetos, impressões. Segundo Kant (2001), receptividade das impressões é "a capacidade de receber representações" (p.114). Diante dessas afirmativas, a abordagem da percepção e da receptividade do professor em relação às Tecnologias Digitais de Informação e Comunicação (TDIC) pode ajudar a compreender a relação do professor com as tecnologias, os fatores que influenciam essa relação, bem como a inserção ou não dessas no processo ensino-aprendizagem, na perspectiva do professor e em como ele assimila essas representações.

Nos processos de integração das TDIC no contexto educacional, programas são implementados na tentativa de aproximar a realidade tecnológica informacional e comunicacional às salas de aula. Tais programas, normalmente, possuem em sua base a distribuição de recursos tecnológicos, seguidas de propostas de formações ao corpo docente para seu uso. Estudos de Almeida (2011), Bernardo (2013), Moran (2005), Valente (2014) evidenciam a descontinuidade de programas que possuem sua base à tecnologia no contexto escolar, a falta de formações que atendam às necessidades reais da comunidade escolar, às mudanças nos processos de ensino e aprendizagem ou ainda, um desinteresse na execução desses programas.

Outros estudos evidenciam que o interesse das TDIC no âmbito educacional é diversificado, assim como são as tecnologias, os contextos culturais e os atores envolvidos (INAN, LOWTHER, 2010; SILVA et al, 2011; MOLLIN, RAABE, 2012; FUGIMOTO, ALTOÉ, 2011).

Uma pesquisa no Estado do Texas nos Estados Unidos teve como objetivo investigar os fatores que afetam a integração dos laptops utilizados pelos professores em sala de aula. Foi constatado que os níveis referentes à preparação e as crenças dos professores apontaram para uma forte integração do laptop e que os fatores facilitadores: o apoio global para a tecnologia e o desenvolvimento profissional - auxiliaram nesses índices. Em uma das conclusões, a formação profissional foi citada como fator que aumenta as chances da integração do laptop ao fazer pedagógico dos professores. Os autores apresentam estudos que 
comprovam que os professores se sentem mais preparados se houver apoio administrativo, a colaboração dos colegas e o suporte técnico (INAN and LOWTHER, 2010).

No Brasil, uma pesquisa realizada no sertão nordestino da Paraíba procurou investigar a aceitabilidade dos professores no Projeto Um Computador por Aluno (PROUCA) em duas cidades selecionadas: Patos e Brejo do Cruz, utilizando a teoria TAM - Modelo de Aceitação Tecnológica. Apesar do nível considerável de aceitabilidade, o fracasso do uso dessa tecnologia na sala de aula assenta-se na falta de uma utilização mais intuitiva e natural. Entretanto, a formação recebida pelos professores foi apontada como fator externo positivo. Infere-se que essa formação seja um facilitador para a aceitação dos professores ao uso do PROUCA (SILVA, 2011). Será que o mesmo ocorre nas demais formações?

No entanto, em outra pesquisa que aborda a percepção do professor em relação às TDIC após uma formação continuada, a maioria dos pesquisados esperavam ampliar seus conhecimentos tecnológicos, mas não visavam inseri-los na sua prática pedagógica (MOLLIN, RAABE, 2012). Esse aspecto levantado instiga o porquê, mesmo com os conhecimentos mínimos quanto ao uso das tecnologias, dos professores não inserirem ou integrarem as TDIC na sala de aula.

Percorrendo ainda mais esse universo das TDIC e o contexto educacional, Fugimoto e Altoé (2011) constataram, após um estudo, que a falta de formação dos professores para o uso das TDIC é um dos vários problemas ressaltados pelas 12 professoras participantes deste estudo. Mais outros são evidenciados, tais como: limitações devido à falta de estímulo e incentivo, laboratórios sem infraestrutura e equipamentos sem condições de uso. Evidenciouse também que aplicação das TDIC não está limitada à formação, mas à atitude do professor em relação a elas:

É importante que eles [professores] se apropriem criticamente dessas tecnologias e descubram as possibilidades de utilizá-las em benefício da aprendizagem do aluno. Usar o computador como um instrumento para a aquisição de novos conhecimentos e para desenvolver a capacidade interativa e criativa na compreensão e na solução de problemas requer a análise do que significa ensinar e aprender. (FUGIMOTO, ALTOÉ, 2011, p. 5608)

$\mathrm{Na}$ Alemanha, estudos com recursos tecnológicos de tecnologia móvel apontam atitudes positivas por parte dos professores a essa ferramenta, mas possuem reservas consideráveis devido a problemas de infraestrutura, ocasionando restrição a intenção do seu uso pedagógico com mais frequência (LFENTHALER, SCHWEINBENZ, 2013). 
Essas são algumas abordagens dadas ao tema TDIC no contexto educacional. Mas o campo é diversificado, amplo e novas práticas e estudos surgem. Nesta pesquisa a questão norteadora acerca dessa temática é: Quais são as percepções e receptividade dos professores da rede pública do ensino médio quanto ao Tablet Educacional no contexto escolar?

Nesta perspectiva, torna-se relevante à questão no intuito de desvendar o porquê da aceitação ou rejeição dos recursos tecnológicos no contexto educacional, suas impressões, bem como o comportamento frente a eles, para desta forma, complementar os saberes científicos e contribuir na inferência de sucesso ou falha na implementação de programas que apresentam a tecnologia aliada à educação.

O recurso tecnológico selecionado nesta pesquisa foi o tablet, que faz parte do Projeto Educação Digital (2012), iniciativa do Ministério da Educação - MEC, para o uso pedagógico do mesmo. Esse projeto do MEC possui como objetivo oferecer instrumentos e formação aos professores e gestores escolares para o uso das tecnologias no processo de ensino e aprendizagem.

No Distrito Federal (DF), tal projeto pretende atender todas as escolas do Ensino Médio. Serão envolvidos em torno de 3.050 professores com acesso e manuseio aos tablets além de outros itens que o compõem, como computador interativo desenvolvido pelo MEC. Essa ação faz parte do Programa Nacional de Tecnologia Educacional - PROINFO e o acompanhamento dos projetos deste programa na rede pública do Distrito Federal está a cargo do Núcleo de Tecnologia Educacional (NTE) ${ }^{1}$ de cada região administrativa em parceria com a Escola de Aperfeiçoamento dos Profissionais de Educação do Distrito Federal (EAPE).

A cultura digital permeia a escola pelo fato de os professores e principalmente seus alunos "nativos digitais", termo criado por Prensky (2001) para retratar os "falantes nativos" da linguagem digital dos computadores, vídeo games e internet, terem contatos frequentes com as tecnologias. A inserção das tecnologias no processo de ensino e aprendizagem pode contribuir para aproximar professores e alunos. No entanto, essa inserção passa primeiramente pela aceitação ou não do professor, para em outro momento proceder à inclusão e possíveis transformações na sala de aula. "Nunca é demais ressaltar que nenhuma inovação acontece se as pessoas forem resistentes a ela. Quando a inovação se impõe sem a capacitação dos

\footnotetext{
${ }^{1}$ O Núcleo de Tecnologia Educacional faz parte da estrutura do programa PROINFO, e de acordo com as diretrizes deste programa, ele é uma estrutura descentralizada de apoio permanente ao processo de introdução das tecnologias de informação e comunicação nas instituições educacionais, sendo espaços também destinados à formação continuada de professores dessas tecnologias.
} 
sujeitos, tem o que Paulo Freire chamava de consciência mágica, que é o oposto de consciência crítica." (NEVES, 2005, p.90).

Nesse sentido, a discussão de programas com foco na tecnologia no âmbito escolar, em como incorporá-los, quais seus efeitos e sua eficácia, o olhar do professor diante desse cenário, sua postura, entre outros temas, surge a cada ato desta natureza. Essa preocupação é antiga, ocorre a cada inserção de um recurso midiático no meio pedagógico apresentando questões de reflexão para a devida incorporação e integração ao ambiente escolar. Ainda hoje há questionamentos e estudos acerca da TV e as linguagens adjacentes. Com o tablet não seria diferente, pois, a convergência das diversas mídias e linguagens em um mesmo aparelho, e este, interagindo com os dispositivos são elementos que podem enriquecer o processo de ensinar ou não.

Em meio a tanta mudança, e para tratar de um tema tão atual, reporto-me a estudiosos como Papert (2008), Demo (2008), Jenkins (2012), Prensky (2012) para fundamentar e ampliar minhas reflexões. Foi empregado nesta pesquisa o método misto que explora tanto dados quantitativos, quanto qualitativos. Essa combinação foi necessária devido à abrangência e complexidade do fenômeno em questão e que poderá embasar o entendimento do objeto de pesquisa. A Teoria Unificada de Aceitação e Uso da Tecnologia (UTAUT) contempla o método quantitativo, enquanto que a entrevista faz o aporte qualitativo.

O interesse ao objeto de estudo advém da minha trajetória como multiplicadora de um Núcleo de Tecnologia Educacional - NTE, que já perfaz 08 anos. Minha função concentra-se na formação continuada dos professores para o uso das diversas tecnologias que estão disponibilizadas no âmbito escolar. Durante esse período e à frente de cursos voltados ao tema em questão, vi e vivenciei momentos de aceitação veemente por parte dos professores a tais recursos, bem como a sua rejeição imediata as Tecnologias Digitais de Informação e Comunicação (TDIC). Presenciei também, a busca constante, por parte dos professores, de novas práticas com o intuito de inovar as relações entre os sujeitos, bem como, da forma de ensinar. Uma busca pela aproximação ao mundo real, fora dos muros escolares. E nessa busca registra-se a insegurança pelo desconhecido ou pelo novo, apresentado aqui pela inserção dessas tecnologias no ensino-aprendizagem.

Considerando a importância do tema e refletindo sobre o contexto atual com a inserção de mais uma tecnologia no contexto educacional para ser utilizada pelos professores da rede pública de ensino: o Tablet Educacional, as seguintes questões surgiram:

Qual o nível de aceitação do professor a inserção do tablet no contexto educacional? 
$>$ Quais são as expectativas dos professores em relação ao curso de formação oferecido pela Instituição?

○ Dimensão técnica e organizacional;

○ Dimensão pedagógica.

Quais são as expectativas quanto ao uso do tablet e seus recursos na execução de tarefas pedagógicas?

> Como o professor avalia a necessidade dessa tecnologia- tablet- no âmbito escolar?

Nesse sentido, o objetivo geral dessa pesquisa foi o de analisar as percepções dos professores cursistas do Projeto Educação Digital e sua receptividade ao Tablet Educacional como ferramenta pedagógica. Por conseguinte, desenvolveram-se os seguintes objetivos específicos:

1. Investigar o nível de aceitação dos professores ao recurso tecnológico no âmbito escolar, o Tablet Educacional;

2. Identificar as expectativas dos professores em relação à formação ofertada para o uso pedagógico do Tablet educacional;

3. Analisar as expectativas dos professores em relação ao Tablet Educacional, seus recursos na execução de tarefas pedagógicas;

4. Conhecer a necessidade desse recurso tecnológico no âmbito escolar.

Diante do exposto, esta pesquisa encontra-se organizada em oito partes: a introdução, que situa o leitor acerca da proposta de investigação, apresentando os objetivos desse estudo que surgiram a partir da questão norteadora e adjacentes. Estudos que justificam a temática, contextualização da pesquisa e meu interesse. Bem como, teóricos que subsidiaram e fundamentaram essa dissertação; seguida de seis capítulos e as considerações finais, que compõem a última parte desse trabalho investigativo.

O primeiro capítulo é destinado a contextualizar o cenário desta pesquisa com um histórico tecnológico e os programas educacionais institucionais voltados às tecnologias, no intuito de mostrar o gradual aumento dos meios tecnológicos na escola, que culmina na mais recente inserção, o Tablet Educacional. Há ainda uma apresentação deste tablet e da formação ofertada ao público desta pesquisa, pois trata de mais uma ação governamental complementar ao projeto em questão.

O segundo capítulo aborda alguns conceitos para o vocábulo percepção e destaca para o termo escolhido nesta pesquisa. Numa tentativa de ampliar o tema e complementar o foco desta pesquisa, o tema receptividade e os níveis de aceitação aos recursos tecnológicos são abordados no terceiro capítulo. 
O quarto capítulo se impõe pela necessidade de se conhecer melhor a teoria utilizada nesta pesquisa: A Teoria Unificada da Aceitação e Uso da Tecnologia - UTAUT, por ser nova e pouco conhecida no contexto educacional brasileiro. Este é um dos motivos para a aplicação dessa teoria neste estudo, com uma amostra de professores para detectar suas percepções em relação ao Tablet Educacional.

O quinto capítulo trata da abordagem investigativa percorrida neste estudo, ou seja, a metodologia da pesquisa. O tema e as questões construídas neste estudo levaram ao Método Misto, que engloba as duas abordagens tanto quantitativa como qualitativa. Diante dessa dimensão, esse capítulo está organizado em oito seções: A primeira concerne na dimensão da abordagem mista, explicita os procedimentos quantitativos e o tratamento dado à pesquisa qualitativa, bem como a estratégia assumida para analisar os dados coletados. Em seguida, é caracterizado o contexto de pesquisa. A terceira seção exprime a amostra da pesquisa. $\mathrm{Na}$ quarta seção, os instrumentos de coleta de dados são apresentados: o questionário e a entrevista semiestruturada. Dando sequência, a próxima seção discorre sobre os procedimentos utilizados para a coleta de dados. Na sexta seção, a coleta de dados é exibida, destaque para dados preliminares coletados na fase de teste do instrumento questionário. E por fim, segue as propostas de análise.

O capítulo seguinte contempla a apresentação e interpretação dos dados coletados. Enquanto que no sétimo, há uma discussão desses resultados.

As considerações finais encerram toda a organização do que se esperava com essa pesquisa, articulando com o contexto educacional vigente na procura de responder as questões apontadas no início desse estudo e ainda, lançar um olhar para novos estudos, advindos dessa pesquisa original. 


\section{CAPÍTULO I - UM SOBREVOO NOS PROGRAMAS GOVERNAMENTAIS REFERENTES ÀS TDIC NO CONTEXTO EDUCACIONAL}

Em 1976, Ferkiss anunciava o que se vivencia constantemente com os recursos tecnológicos e a sociedade: "o futuro já está às nossas portas." Naquele momento ele abordava a experiência do homem e sua conquista do espaço por meio da tecnologia. Esse fenômeno, as mudanças e transformações na sociedade humana deveriam ser compreendidos, mas o homem tecnológico, já era, simultaneamente, mito e realidade. Havia um consenso que "a tecnologia é, de uma maneira ou de outra, o fato que está fazendo com que uma nova civilização radicalmente nova seja possível e necessária e fornecendo o seu princípio de organização" (FERKISS, 1976, p.14). Parece que ainda reina esse consenso em pleno séc. XXI. Nota-se que a cada tecnologia a sociedade é impulsionada a se reorganizar, se recriar e uma nova civilização aponta.

A escola enquanto instituição social participa das transformações culturais, contribui com elas e recebe também reflexos dessas transformações. As tecnologias digitais estão presentes na maioria das ações da sociedade e cada vez mais essas tecnologias estão incorporadas ao cotidiano escolar. É possível ver nos corredores ou mesmo nas salas: TV, câmeras, Data show, computadores, Internet e outros aparatos tecnológicos. Essa inserção provoca mudanças nas práticas pedagógicas, nas estruturas e bases educacionais.

\subsection{Os programas governamentais voltados para as TDIC}

$\mathrm{Na}$ busca de inserir a escola e todos envolvidos neste universo tecnológico programas são implementados. Então, nossa procura neste momento foi o levantamento de projetos, no campo governamental brasileiro, que possuíam em suas bases as Tecnologias Digitais de Informação e Comunicação (TDIC). E duas grandes ações apresentam iniciativas relacionadas às tecnologias no contexto educacional: a TV Escola e o Programa Nacional de Tecnologia Educacional- PROINFO.

ATV Escola proposta pelo Ministério da Educação - MEC, em março de 1996, com o objetivo inicial de distribuição de um kit contendo televisão, vídeo cassete, antena parabólica, receptor de satélites e dez fitas para gravações dos programas a 55 mil unidades escolares do ensino fundamental e médio no país. 
Em um seminário sobre os dois anos da TV Escola aqui no Brasil, Sadek ${ }^{2}$ (1998) destaca que:

\begin{abstract}
A idéia do programa é a de que o professor forme uma videoteca, gravando o que lhe interessa, para o seu projeto, para a escola da região. Assim, ele terá formado um repertório fixo e permanente ao seu lado, que poderá usar para a sua capacitação ou instrumento didático. A aquisição desse instrumento de trabalho é fundamental para a evolução do que queremos, pois o futuro tecnológico está muito mais perto do que parece. (SADECK, 1988 apud BRASIL, 1999, p.24).
\end{abstract}

Atualmente a TV Escola é um canal de televisão com uma programação diária que visa o aperfeiçoamento e valorização dos professores da rede pública, com séries, documentários estrangeiros e produções próprias.

Neste seminário, pesquisas realizadas em torno desse programa evidenciaram dificuldade inicial de aceitação ao mesmo. E ainda que "a apropriação se dá a partir da cultura e da circunstância de vida de cada um.” (MENEZES, 1988, apud BRASIL, 1999, p. 29). Percebe-se que qualquer que seja o tempo ou a tecnologia essa postura de aceitação, apropriação e contexto cultural comumente se apresenta. Outro problema evidenciado na implantação e no aproveitamento do programa durante a capacitação e formação continuada era a falta de estímulo ao professor (BRASIL, 1999).

Naquele período o aparato tecnológico em evidência era a televisão, Bevort (1998) aborda a importância do seu papel e influência na sociedade: “A televisão, hoje, é certamente parte da família, um agente fundamental de socialização para as crianças”. (BEVORT, 1988, apud BRASIL, 1999, pág.86). Ao conduzir o tema para o âmbito educacional, o professor é levado a refletir sobre essa nova mídia, seu papel e sua forma de ensinar. E conforme Carneiro (2007) "a capacidade para compreender e analisar a TV não se adquire apenas consumindo-a; é preciso estudar a linguagem, o discurso e a tecnologia que a permeiam". (CARNEIRO, 2007, p.198) menciona ainda que o professor "é desafiado a apropriar-se de conhecimentos sobre TV para transformar-se em mediador entre as experiências midiáticas dos estudantes e o mundo escolar.". Todas essas questões foram levantadas em um curso de formação para o uso pedagógico da TV: TV na Escola e os Desafios de Hoje, que foram contempladas em uma pesquisa feita com 61 professores do DF para analisar a inserção dessa mídia, a TV, no contexto educacional, a formação e a prática dos educadores; observa-se que

2 Diretor do Departamento de Produção e Divulgação de Programas Educativos da Secretaria de Educação a Distância do MEC / Brasil em 1998, função exercida no período do seminário internacional. Doutor em Comunicações pela Universidade de São Paulo (2006). 
a maioria considerou um ganho no aprendizado a relação da TV e a prática pedagógica em sala de aula, bem como no convívio familiar. Foi salientado também o reconhecimento dessa mídia como instrumento no processo de ensino e aprendizagem, no qual $31 \%$ enfocaram as competências para analisar e selecionar a programaçãoo, e 32\% nos usos dessa mídia como recurso pedagógico (CARNEIRO, 2007, p.201).

Segundo Castells (2011), a associação da revolução tecnológica às tecnologias da informação remodelou a base da sociedade em ritmo acelerado. Porém os processos no contexto educacional persistem em continuar os mesmos, apesar de toda essa revolução acelerada.

Em 1997 foi criado o Programa Nacional de Informática na Educação (PROINFO), pela portaria n $\mathrm{n}^{\circ} 522 / \mathrm{MEC}$ com o objetivo de subsidiar os professores e disseminar o uso pedagógico das tecnologias de informática e telecomunicações na rede pública. O cerne do programa é a distribuição de computadores, recursos digitais e conteúdos educacionais às escolas de todo país. A adesão ao programa cabe aos estados, Distrito Federal e municípios que possuem a função de garantir a estrutura para receber os laboratórios de informática e a capacitação dos professores para o uso dos recursos tecnológicos advindos desse programa. Em 2007, através do decreto $\mathrm{n}^{\circ} 6.300$ (BRASIL, 2007) o programa passou a ser denominado como Programa Nacional de Tecnologia Educacional e nesta reestruturação outros programas se vincularam aos fundamentos de sua base. São eles: Programa Um Computador por Aluno (PROUCA), Programa Banda Larga nas Escolas (PBLE) e o mais recente, o Projeto Educação Digital com a entrega dos tablets.

Antes de se tornar um programa, Um Computador por Aluno (UCA) foi desenvolvido em forma de Projeto, em 2007, com a parceria entre a Presidência da República, Ministério da Educação- MEC e cinco estados do Brasil. O UCA teve como objetivo intensificar as tecnologias da informação e comunicação nas escolas distribuindo computadores portáteis aos alunos da rede pública de ensino, onde cada aluno teria a sua máquina para desenvolver seus conhecimentos. Essa ideia originária foi proposta por Alan Kay ${ }^{3} \mathrm{em} 1968$ após conhecer o trabalho de Seymour Papert com computadores e a linguagem Logo ${ }^{4}$ para resolução de problemas complexos de matemática. Após anos, percebe-se que essa ideia assemelha-se aos tablets, em nossa atualidade, pois para Kay, esse computador deveria ser portátil, interativo e

\footnotetext{
${ }^{3}$ Alan Curtis Kay é um dos cientistas da computação responsável pela criação da linguagem de programação Smaltalk e pelo computador portátil que seria o tablet atual e suas interfaces.

${ }^{4}$ A Linguagem Logo foi criada por Seymour Papert para ser um meio de comunicação entre o computador e a criança, uma linguagem de programação fundamentada na filosofia piagetiana, em que a criança aprende explorando o seu ambiente.
} 
pessoal; além de conectar-se a uma rede para que o usuário pudesse usufruir de facilidades como texto, áudio, imagem, animações.

A primeira fase do projeto teve seu início com cinco escolas em diferentes regiões do país: Escola Municipal Ernani Bruno (São Paulo/SP); Escola Estadual Luciana de Abreu (Porto Alegre/RS); Colégio Estadual Dom Alano Marie Du Noday (Palmas/ TO); CIEP Municipal Prof. ${ }^{a}$ Rosa Conceição Guedes (Piraí/RJ) e Centro de Ensino Fundamental no 1 do Planalto (Brasília/DF) ${ }^{5}$. Cada escola recebeu um protótipo de laptop doado por empresas interessadas no projeto. Essa experiência foi nomeada de pré-piloto. Durante essa fase, um grupo de trabalho, formado por especialistas de várias universidades no uso das TICs na Educação, auxiliou na implementação do projeto em três momentos: formação dos multiplicadores dos NTEs e dos professores envolvidos; avaliação do projeto, do notebook, da formação, do ensino-aprendizagem e pesquisa de material teórico-pedagógico, de experiências exitosas, desafios e outros. Apesar dos entraves o projeto ganhava mais respaldos e apoio para sua continuidade.

E assim como em outros países (Austrália, Estados Unidos, Uruguai, Portugal e África) em 2010, o projeto laptop 1-1 foi implantado no Brasil. A segunda fase, intitulada: Piloto, iniciou com a distribuição de 150 mil equipamentos a 300 escolas entre urbanas e rurais, atendendo todas as regiões do país. No mesmo ano, o projeto passa para o patamar de programa- PROUCA e com fundos próprios ou do Banco Nacional de Desenvolvimento Econômico e Social (BNDES) os estados e municípios puderam adquirir os equipamentos e implementá-los na sua localidade.

Pontos inovadores são destacados na cartilha do programa produzida pelo MEC, são eles: mobilidade, pois o uso do equipamento pode ser dentro e fora da escola; conectividade através das redes sem fio; incentivo ao uso de softwares livres, inserção a cultura digital; e seu uso pedagógico por meios das diversas mídias disponíveis no equipamento. Todos esses elementos possibilitam rupturas com a escola tradicional de horários e locais fixos para a aprendizagem e detenção do conhecimento.

Para Bernardo (2013) os dispositivos móveis digitais (telefone celular, smartphones, netbooks, tablets, entre outros) e a aprendizagem móvel apresentam uma nova modalidade de ensino que vêm ganhando atenção nos ambientes educacionais. A Organização das Nações Unidas para a Educação, a Ciência e a Cultura (UNESCO) atenta com o crescimento desses dispositivos nas mãos dos jovens estudantes e suas possibilidades vem promovendo encontros

\footnotetext{
${ }^{5}$ Dados obtidos no site institucional do programa: http://www.uca.gov.br/institucional/experimentosFase1.jsp. Acesso em 13 de julho de 2014.
} 
para incentivar pesquisas e estudos. Esses encontros apontam no cenário mundial "a crença de que por meio de dispositivos móveis digitais é possível construir processos formativos" (BERNARDO, 2013, p.4).

No entanto, Santos e Braga (2012) destacam que a situação da Educação Infantil mediada pela informática, mas especificamente com o PROUCA no Distrito Federal evidencia que "o papel da escola como vetor educativo se esvazia e as situações de uso do computador na Educação Infantil passam ao largo das possibilidades de aprendizagem, interação e interatividade que elas poderiam proporcionar.” (SANTOS; BRAGA, 2012, p.80).

Em 2008, o Programa Banda Larga nas Escolas (PBLE) é lançado. Ele se agrega ao PROINFO no intuito de subsidiar todos os municípios e escolas públicas urbanas brasileiras na infraestrutura de rede para suporte de conexão à internet. A partir de então, "A aprendizagem não ocorre apenas em determinado contexto, mas gera novos contextos por meio da interação contínua que acontece com o uso das tecnologias." (ALMEIDA et al., 2011, p.31).

Iniciativas governamentais, em parceria com o MEC, estão acontecendo para que mais recursos tecnológicos cheguem ao âmbito escolar no intuito de acompanhar as transformações. Castells (2011, p.47) evidencia que “[...] o Estado pode ser, e sempre foi ao longo da história, na China e em outros países, a principal força de inovação tecnológica". E com o propósito de inovação, em 2007, o Programa PROINFO recebeu uma reformulação e agregou a formação continuada em vários processos para o uso didático-pedagógico das TDIC no contexto escolar, enfoque maior na reflexão crítica sobre a prática pedagógica executada, ação essa que vai ao encontro às ideias de Freire (1996) ao abordar a formação permanente como momento fundamental, pois "É pensando criticamente a prática de hoje, ou de ontem que se pode melhorar a próxima prática." (FREIRE, 1996, p.39). Esse novo enfoque alterou também a denominação do programa, mencionado acima, para: Programa Nacional de Formação Continuada em Tecnologia Educacional - ProInfo Integrado -.

Outras ações ocorrem simultaneamente para fortalecer o programa: distribuição de equipamentos tecnológicos, por exemplo, o Projetor Proinfo; Ofertas de conteúdos e recursos multimídia e digitais disponíveis pelo Portal do Professor, Portal do Aluno, Domínio Público e pelo Banco Internacional de Objetos Educacionais. Além de ambientes virtuais de aprendizagem como E-Proinfo e cursos de educação superior com base na política acadêmica de portas abertas pela Universidade Aberta do Brasil-UAB.

Nesta mesma vertente tem o Projeto Educação Digital que tem no seu cerne, o tablet educacional, o recurso tecnológico da nossa pesquisa. A seguir tratarei desse projeto para 
conhecê-lo melhor e algumas considerações acerca da inserção dessa ferramenta no contexto escolar.

\subsection{O Projeto Educação Digital, o Tablet Educacional e suas transformações}

O Projeto Educação Digital é a mais recente ação governamental, lançado em 2012, articulado com o ProInfo Integrado, o objetivo é a distribuição de tablets aos professores do ensino médio como mais uma ferramenta pedagógica. Os equipamentos móveis chegam como uma nova proposta de dinamicidade de conhecimento que pode enriquecer o processo ensinoaprendizagem. Os recursos/aplicativos que se encontram nesses dispositivos tecnológicos também permitem a construção ou reconstrução de conhecimentos. A lógica mais próxima do nosso pensamento se apresenta, possibilitando o desenvolvimento de várias habilidades em um só momento.

O tablet por ser o dispositivo tecnológico portátil móvel mais contemporâneo e que apresenta uma série de possibilidades ao usuário, surge como proposta de inovação no contexto escolar. Essa realidade não é característica apenas do Brasil. A distribuição dessa ferramenta aos professores e aos seus alunos já foi realizada em países como Portugal, Espanha e Estados Unidos.

A inserção do tablet e demais recursos midiáticos na prática pedagógica do professor podem ser vistos como uma tentativa de integração da vida fora da escola ao cotidiano escolar. Essa aproximação da escola à realidade após os muros propicia aos alunos uma experiência antecipada dos desafios que poderão surgir. São artefatos que trazem consigo uma conotação de mudança e modernidade, e que podem transferir para a educação essas características também. Que segundo Lemos (2010) irão transformar as relações na sociedade e também no campo educacional:

\footnotetext{
As tecnologias móveis e sem fio estão transformando a relação entre as pessoas e os espaços urbanos em que elas vivem, criando novas formas de mobilidade. Entende-se que a possibilidade de o sujeito levar consigo o objeto de estudo, ou de poder acessá-lo de qualquer lugar, potencializa o uso de dispositivos móveis na educação. Desse modo, os dispositivos móveis tipo tablets podem ser vistos na perspectiva de artefatos culturais, assumindo um enfoque desde uma perspectiva de utilização pedagógica. (LEMOS, 2010).
}

De forma bem sucinta pode-se dizer que a escola necessita da utilização de uma meta linguagem que torne explícita aos alunos, os objetivos e necessidade do uso dos instrumentos tecnológicos, não apenas para distração, mas sim, como elementos que favoreçam o 
desenvolvimento individual e coletivo, propiciando ao aluno uma fluência em TDIC, que está relacionada com a capacidade de selecionar conhecimentos, reformulá-los criativamente e gerar informação por meio do uso dos recursos tecnológicos. Trata-se de aprender com ou através desses recursos tecnológicos. E tudo isso perpassa inevitavelmente pelo professor. No entanto, muitos professores possuem receio em lidar com tecnologias em suas aulas, pois são impulsionados a condição de aluno. Condição esta devido a pouca ou nenhuma vivência com os recursos tecnológicos ou ainda pela rotatividade de recursos, aplicativos que as tecnologias apresentam que dificultam o seu acompanhamento. Segundo Papert (2008, p.14):

A habilidade mais determinante do padrão de vida de uma pessoa é a capacidade de aprender novas habilidades, assimilar novos conceitos, avaliar novas situações, lidar com o inesperado. Isso será cada vez mais verdadeiro no futuro: a habilidade para competir tornou-se a habilidade de aprender.

Ou ainda, segundo Demo (2001, p.20):

Aprender é substancialmente saber mudar-se e mudar, estabelecendo consigo mesmo, com os outros e o meio ambiente relacionamento dinâmico de estilo reconstrutivo. É a estratégia que temos para não sermos massa de manobra nas mãos dos outros ou do ambiente hostil.

E inteirando um pouco mais sobre aprender enquanto ensina, Freire (1996, p.44) destaca:

No fundo, passa despercebido a nós que foi aprendendo socialmente que as mulheres e homens, historicamente, descobriram que é possível ensinar. Se estivesse claro para nós que foi aprendendo que percebemos ser possível ensinar, teríamos entendido com facilidade a importância das experiências informais nas ruas, praças, no trabalho, nas salas de aula das escolas, nos pátios dos recreios, em que variados gestos de alunos, de pessoal administrativo, de pessoal docente se cruzam cheios de significação. (FREIRE, 1996, p.44)

Pode-se perceber que tanto para Freire (1996), quanto para Demo (2001) e para Papert (2008) o cerne consiste em que aprender novas habilidades, vem envoltas de desafios, mudanças, mas que são possíveis de serem aprendidas no seu manuseio, no dia-a-dia. E inerentes à educação, aos professores e alunos. E não será diferente ao introduzir uma nova tecnologia neste contexto. O laptop dispõe de diversos recursos, como editores eletrônicos, inserção de figuras, formatação textual adequada, correção da ortografia, bem como a exploração da internet com o uso de correios eletrônicos e postagens em blogs. O uso desses recursos constitui em instrumento valioso no desenvolvimento na produção textual, na 
interação e em outros contextos educativos. A navegação pela internet e suas leituras, bem como de textos no formato eletrônico pode também favorecer o hábito de leitura e outras habilidades que dificilmente conseguiria sem estes meios tão comuns nos dias atuais. São novas formas de ensinar mais próximas da vivência dos nossos alunos e requer novos aprendizados do professor. É a tentativa de trazer as experiências informais com o uso desses recursos tecnológicos, cheios de significação para o âmbito escolar. Porém, muitos professores desconhecem tais possibilidades, tais habilidades ou por receio às mudanças, ou por falta de familiaridade com o recurso.

Cysneiros (1996) entende que o uso de processador de texto, o ambiente Windows e seus aplicativos, disponíveis fora da escola em uso pedagógico são como "tipo de "puente" de la escuela com la vida real no era viable em épocas anteriores a la informática"6 (p.49). Esses e outros recursos ampliam as possibilidades de aprender, interagir e compartilhar tornando-se aliados ao ensino, mas que ainda não sobressaíram como ações exitosas no campo educacional, apesar das experiências vivenciadas por países desenvolvidos, mencionado por esse estudioso:

Todavía del lado teórico, tenemos siempre presentes las enseñanzas de la historia de la tecnología educativa en el primer mundo [viii, ix] y no en América Latina. La literatura nos enseña que en los países desarrollados las tecnologías en la escuela comienzan con una retórica de elevadas expectativas y terminan en un uso limitado. En nuestro continente ninguna tecnología educativa del pasado ha tenido éxito. ${ }^{7}$ (CYSNEIROS, 1996, p.49)

Todo esse cenário tecnológico pode alterar a organização da escola e seus agentes, desde o gestor, o secretário, o coordenador, o professor, os pais, até ao aluno. Mas, nesta pesquisa o foco será o professor, principal "sistematizador de experiências" que oferece possibilidades de aprendizagens através das conexões para recorrências e experimentações entre os alunos, propiciando conhecimento e a interatividade. E segundo Jenkins (2012): “contradições, conflitos e múltiplos pontos de vista já são esperados em momentos de transição, época de convergência das mídias, inteligência coletiva e cultura participativa." (JENKINS, 2012, p.37). Uma forma de contradição pode ser a incorporação das TDIC de forma conservadora em sala de aula, apontada como inovação conservadora:

\footnotetext{
${ }^{6}$ Tipo de ponte da escola com a vida real não era viável em épocas anteriores a informática. (tradução nossa)

7 Todavia, o lado teórico, temos sempre presente os ensinamentos da história da tecnologia educacional no Primeiro Mundo [viii, ix] e não na América Latina. A literatura nos ensina que nos países desenvolvidos as tecnologias na escola começam com uma retórica de grandes expectativas e terminam em uso limitado. Em nosso continente nenhuma tecnologia educacional no passado tem sido bem sucedida. (tradução nossa)
} 
Usos del computador que no se mezclan cualitativamente con la rutina de la escuela, del profesor y del alumno, además de no explorar los recursos únicos del computador, presentan un elemento pernicioso de aparentan un cambio sustantivo en el proceso de enseñanza-aprendizaje, cuando en la realidad apenas se cambia su apariencia, tratando de volver novedosos los viejos modelos, las viejas concepciones del contenido y de la enseñanza. ${ }^{8}$ (CYSNEIROS, 1996, p.53)

Cysneiros (1996) aponta para uma inovação não tanto inovadora, mas neste período de convergência os impasses, os receios, as falhas, as expectativas estão em evidência e refletem na recepção primária do nosso mentor, o professor e em suas ações futuras, tais como: a apropriação das tecnologias, a efetivação para incorporá-las em sua prática e em como ensinar com esses recursos de forma inovadora. A proposta é de uma pedagogia midiática, na qual uns ensinam os outros, crianças ensinam crianças, que ensinam adultos, que ensinam crianças e adultos, tudo isso por meio das diversas mídias. Essa pedagogia com e para as mídias aflige todos no âmbito educacional. E influencia o papel do professor, ora ensinando, ora aprendendo.

Esse grande desafio apresenta-se de forma abrupta com a introdução das Tecnologias Digitais de Informação e Comunicação- TDIC no âmbito escolar provocando alteração no papel do professor e ainda sugerindo mudanças na relação de processo ensino aprendizagem. O processo de ensino aprendizagem acontece na relação entre seres imbuídos de conhecimentos e experiências prontos a se corresponderem. A concepção básica é a do professor como o mentor do conhecimento, o ser dotado. Enquanto que o aluno é o receptor desse conhecimento. Tardy (1976) já pronunciava essa relação no relacionamento pedagógico habitual: "o professor sabe, os alunos não sabem, ou não sabem grande coisa." (TARDY, 1976, p.26). No entanto, essa relação em um contexto tecnológico e educacional expõe uma inversão de papéis, confirmada em:

Com o cinema e a televisão, ainda se constata uma defasagem entre o que os alunos sabem e o que os professores sabem, mas em sentido contrário: é o professor o ignorante; ele é quem deve usar as orelhas de burro. A taxa de frequiência das crianças e dos adolescentes é superior à dos adultos e se, nessa comparação, substituirmos os adultos pelos professores, a desproporção ainda será maior. (TARDY, 1976, p.26)

\footnotetext{
${ }^{8}$ Usos do computador que não se misturam qualitativamente com a rotina escolar, do professor e do aluno, além de não explorar os recursos próprios do computador, apresenta um elemento pernicioso que aparenta uma alteração substancial no processo de ensino-aprendizagem, quando na realidade apenas sua aparência é alterada, tentando transformar velhos modelos em novos, as antigas concepções de conteúdo e de ensino. (tradução nossa)
} 
Apesar dos termos: "ignorante" e "orelhas de burro" utilizadas naquela época e que não condizem mais com o panorama educacional atual, pode-se perceber que Tardy (1976) já anunciava o professor como um imigrante digital e por outro lado, o aluno, um nativo digital, que possui mais desenvoltura com o uso das tecnologias do seu tempo. Esses termos foram ressaltados por Prensky (2001) para reportar às atitudes dos nascidos em uma era pré-digital, os imigrantes; e daqueles que só conhecem essa cultura digital, os nativos digitais. Não se trata necessariamente de que um ou outro sabe mais, ou melhor, das tecnologias digitais, mas se referem a vivências e relações nesse contexto. Essa dicotomia torna-se pouco relevante atualmente. A busca passa a ser pela sabedoria digital, Prensky (2009) a conceitua como:

Digital wisdom is a twofold concept, referring both to wisdom arising from the use of digital technology to access cognitive power beyond our innate capacity and to wisdom in the prudent use of technology to enhance our capabilities. ${ }^{9}$ (PRENSKY, 2009, p.S.n)

No entanto, os termos utilizados ilustram que a inserção tecnológica desestrutura o papel do professor de detentor do conhecimento e do aluno, de mero receptor. Papéis esses construídos ao longo dos tempos e desconstruídos com a era digital. Esse cenário apresenta-se inicialmente como um obstáculo e provavelmente interfira no modo de lidar com essas tecnologias na escola e no fazer pedagógico. A esse respeito, o estudo de Molin; Raabe (2012) revela que há um descompasso na assimilação dos conhecimentos tecnológicos entre o professor e o aluno. O autor acrescenta que essa situação se deve a uma interação/convívio maior dos mais jovens com a tecnologia.

Fato levantado também por Tardy (1976) quando menciona que a nova geração nasceu em um universo em que a imagem é bastante presente e evidente no cotidiano e na cultura dessa geração. Diferentemente, o adulto, é obrigado a fazer uma conversão mental e vive em um processo de aculturação para se aproximar dessa geração. Neste período, a década de 70, o auge tecnológico era a TV e o cinema. No entanto, esse desafio persiste a cada nova tecnologia, conforme nos relata Moran (2005):

Há uma crescente dificuldade de comunicação entre o professor adulto e as crianças e os jovens. A forma de organizar a informação e de transmiti-la do professor é mais seqüencial, abstrata, erudita. Crianças e jovens, que

\footnotetext{
${ }^{9}$ Sabedoria Digital é um conceito duplo, referindo-se tanto a sabedoria a partir do uso da tecnologia digital para acessar poder cognitivo além de nossa capacidade inata e à sabedoria no uso prudente de tecnologia para melhorar as nossas capacidades.
} 
navegam intensamente pela Internet, vêem muita TV e participam de contínuos jogos eletrônicos, pensam de uma forma mais sensorial, concreta, plástica, multimídica, "linkada", coloquial. Eles se expressam com muita intensidade emocional e pouca riqueza verbal erudita. [...] Temos de aproximar ao máximo nossa linguagem da dos alunos, nossa abordagem da deles, nossas vivências das deles. Mas sempre haverá uma diferença enorme de percepção e formas de expressão. (MORAN, 2005, p.98)

Diante desse contexto, estudos acerca da percepção, da formação e da prática pedagógica com as diversas tecnologias são necessários para entender a relação das mesmas no contexto educacional e auxiliar no processo de ensino e aprendizagem. Dando continuidade ao tema e com enfoque mais individual, segue uma breve apresentação do Tablet Educacional, recurso tecnológico, objeto de estudo desta pesquisa. Na sequência é explicitada a estrutura da formação oferecida aos professores para uso do equipamento. Esses dois momentos (apresentação do tablet e estrutura da formação) traz um recorte da situação do programa no intuito de mostrar o contexto do Distrito Federal. E a partir dessa realidade analisar a receptividade do professor sobre o Tablet Educacional.

\subsubsection{O Tablet Educacional distribuído pelo MEC}

Esse dispositivo faz parte do Programa Educação Digital, iniciativa do MEC em 2012. O Tablet Educacional trata-se de um dispositivo portátil que permite acesso à internet, a visualização e edição de textos, jogos, vídeos, músicas, leitura de livros digitais e que está voltado para atender a professores, em uma primeira etapa; e aos alunos, em segunda etapa; da rede pública do ensino médio de todo Brasil. Foram produzidos e distribuídos por duas empresas: Positivo e CCE. Segue imagem do equipamento:

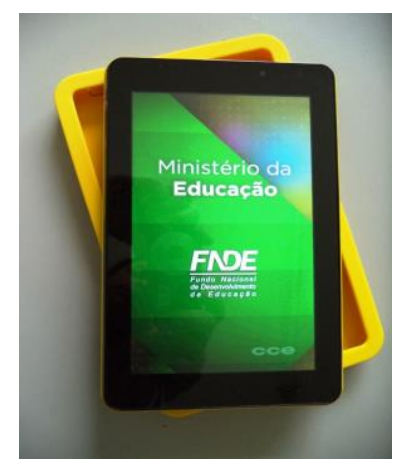

Figura 1 - O Tablet Educacional ${ }^{10}$

\footnotetext{
${ }^{10}$ Imagem retirada do site: http://2.bp.blogspot.com/-siYz8xOdLBI/UpYgbFasOwI/AAAAAAAAAPI/i_dVQLflmA/s1600/DSC00226.JPG. Acesso em 04/08/2014.
} 
Os dados a seguir foram distribuídos num quadro, no qual há as especificações técnicas do Tablet Educacional e de outros dois tablets, disponíveis na rede comercial. A apresentação comparativa do Tablet Educacional com outros dois equipamentos similares e disponíveis no comércio a qualquer usuário, também intitulados tablets, tornou-se conveniente para evidenciar suas principais características e desempenho para posteriores análises com as afirmativas dadas pelos professores durante a coleta de dados. Seguem as especificações técnicas:

Quadro 1 - Especificações Técnicas do Recurso Tecnológico - Tablet

\begin{tabular}{|c|c|c|c|}
\hline & Tablet Educacional & Galaxy Tab 38.0 & LG G PAD \\
\hline Marca & $\begin{array}{ll}\text { Positivo } & \text { YPY } \\
\text { AB10D FNDE } & \end{array}$ & Samsung & LG \\
\hline Processador & Clock de $1 \mathrm{Ghz}$ & $\begin{array}{l}\text { Dual-core de } 1.5 \\
\mathrm{GHz}\end{array}$ & $\begin{array}{l}\text { Quad-core de } 1.7 \\
\text { GHz }\end{array}$ \\
\hline Memória RAM & 1 Gigabyte & 1,5 Gigabytes & 2 Gigabytes \\
\hline Tela & $\begin{array}{l}\text { LCD de } \quad 9,7 \\
\text { polegadas }\end{array}$ & $\begin{array}{l}\text { HD de } 1280 \text { × } 800 \text { de } \\
8 \text { polegadas }\end{array}$ & $\begin{array}{l}\text { Full HD de } 8.3 \\
\text { polegadas }\end{array}$ \\
\hline Sistema Operacional & $\begin{array}{l}\text { Android 4.0; } \\
\text { Português Brasil }\end{array}$ & $\begin{array}{l}\text { Android } 4.2 \text { Jelly } \\
\text { Bean }\end{array}$ & $\begin{array}{l}\text { Android 4.2.2 Jelly } \\
\text { Bean }\end{array}$ \\
\hline Armazenamento & $\begin{array}{l}16 \text { GB } \text { (com } \\
\text { possibilidade de } \\
\text { expansão de até } \\
\text { 32GB com cartão } \\
\text { Micro SD Card) }\end{array}$ & $\begin{array}{l}16 \text { GB } \\
\text { possibilidade } \\
\text { expansão de até } \\
\text { 48GB com cartão } \\
\text { Micro SD Card) }\end{array}$ & $\begin{array}{l}16 \text { GB } \text { (com } \\
\text { possibilidade de } \\
\text { expansão de até } \\
68 \text { GB com cartão } \\
\text { Micro SD Card) }\end{array}$ \\
\hline Conectividade & $\begin{array}{l}\text { Rede sem fio IEEE } \\
802.11 \mathrm{~b} / \mathrm{g} / \mathrm{nTM} \text {; } \\
\text { BluetoothTM } 2.1+ \\
\text { EDR }\end{array}$ & $\begin{array}{l}\text { Rede sem fio; } \\
\text { 3G; } \\
\text { Bluetooth e GPS }\end{array}$ & $\begin{array}{l}\text { Rede sem fio; } \\
\text { Bluetooth e GPS }\end{array}$ \\
\hline Câmeras & $\begin{array}{l}\text { Duas: } \\
\text { - Frontal VGA; }\end{array}$ & $\begin{array}{l}\text { Duas: } \\
\text { - Frontal }\end{array}$ & $\begin{array}{l}\text { Uma: } \\
\begin{array}{l}\text { - } \quad 5,0 \mathrm{MP} .\end{array}\end{array}$ \\
\hline
\end{tabular}




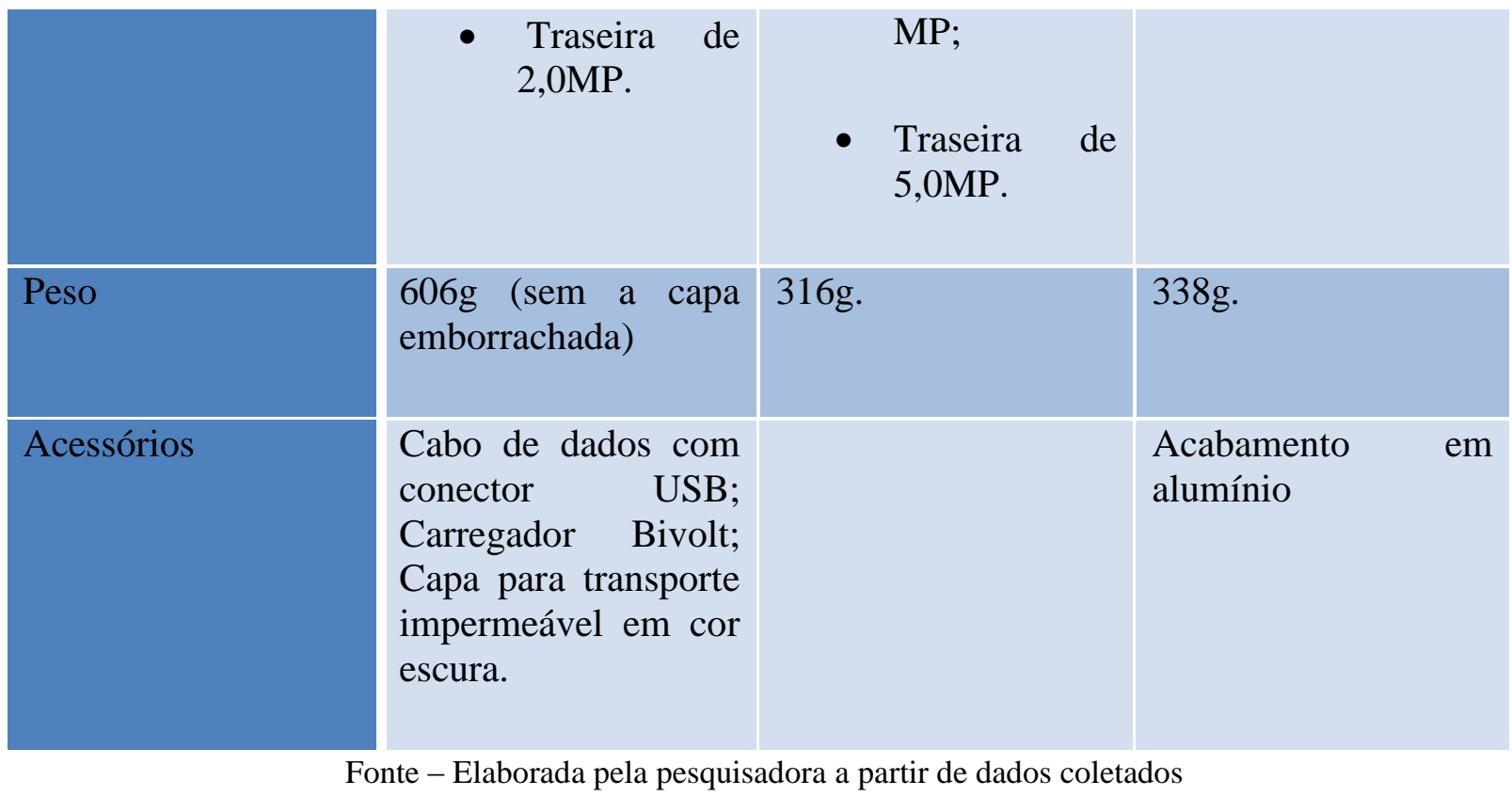

O Tablet Educacional possui ainda, em relação aos aplicativos, os seguintes recursos:

- Ferramentas do Google:

- Google pesquisa: dá acesso à ferramenta de busca do Google;

○ Opção Voice: permite a busca no site do Google através da voz;

- Google play: refere-se à loja virtual do Google que possui diversos aplicativos para o sistema operacional Android.

- Câmera;

- Gravador de áudio;

- Mec Mobilidade: trata de uma loja virtual do Ministério da Educação e o Governo Federal, no qual há aplicativos exclusivos desenvolvidos para melhorar a experiência com o tablet;

- Dropbox: aplicativo que armazena arquivos nas nuvens;

- Astro: aplicativo que permite o acesso ao conteúdo da memória interna e do cartão microSD do aparelho.

Nota-se que não há nenhum aplicativo específico para o âmbito educacional que justifique o nome dado ao equipamento. E ainda que em muitos quesitos técnicos, ele apresenta-se inferior em comparação com os demais. Essas inferências são abordadas em um dos instrumentos da pesquisa no intuito de verificar se este fator influencia ou não na receptividade. 
Essas especificações, seus aplicativos e recursos são abordados num curso de formação ofertado pelo governo. Esta ação governamental está prevista no Projeto Educação Digital: fornecimento e formação para o uso das TICs no processo ensino aprendizagem. A seguir, segue a estrutura do curso, pois a mesma faz parte de um dos itens mencionados na estrutura da Teoria UTAUT como condições facilitadoras para o uso.

\subsubsection{O Curso de Formação oficial proposta para o uso do Tablet}

O Distrito Federal atendendo as políticas do MEC na inserção das tecnologias nas práticas pedagógicas propõe o curso: Tablet Educacional como Ferramenta Pedagógica para os professores de Ensino Médio voltado para o uso didático e pedagógico dos Tablets e das Tecnologias de Informação e Comunicação (TIC). O curso de formação foi realizado em parceria com a Secretaria de Estado de Educação (SEDF), a Subsecretaria de Modernização Tecnológica, a Escola de Aperfeiçoamento dos Profissionais de Educação (EAPE), e com a Escola de Governo. Esse curso é considerado nesta pesquisa um constructo facilitador porque representa o grau de infraestrutura pedagógica propiciada pelo Estado. No entanto, essa afirmativa será analisada durante a pesquisa.

O curso foi ofertado em 2013 como prerrogativa a todos os professores que optaram por receber do MEC o Tablet Educacional. No DF, totaliza 3.051 professores, que foram distribuídos em 61 turmas com 50 cursistas cada.

O curso iniciou no dia 03 de Setembro de 2013 com previsão de término para última quinzena de novembro do mesmo ano. O formato do mesmo foi híbrido: parte presencial e outra parte virtual no Moodle da própria escola: http://www.Eape.se.df.gov.br/ead, distribuída à carga horária da seguinte maneira: Carga Horária Direta de 12 horas; Carga Horária Online de 78 horas; Total: 90 horas.

Como fundamentação teórica, a EAPE respaldou-se em Vineet Madan, Vice Presidente of McGraw-Hill Higher Education e Labs ${ }^{11}$ que justifica o uso do Tablet na Educação com seis razões. E dentre elas cinco adéquam à realidade desse curso de formação e seu público. São elas:

1. Tablets são o melhor caminho para mostrar textos digitais e outros utilitários.

2. Os alunos e o ambiente de salas de aulas já estão mentalmente prontos para o uso dos tablets.

\footnotetext{
${ }^{11}$ Centro de Inovação Digital de Columbus (USA) com escritórios espalhados em diversos países. O ensino é totalmente digital com foco nas habilidades do século XXI. Fornece experiências de aprendizagens personalizadas.
} 
3. Os tablets combinam com o estilo de vidas dos estudantes contemporâneos;

4. Os tablets integram educação com tendências de TICs.

5. Os tablets estão cada vez mais disponíveis e fazem parte de cultura contemporânea.

A metodologia online teve como propósito constituir uma comunidade em rede de aprendizagem colaborativa e solidária.

Os objetivos de aprendizagem deste curso de formação visavam compreender as transformações sociais e tecnológicas; Compreender e utilizar o sistema operacional Android e seus aplicativos; Conhecer a importância das TICs e sua utilização adequada; Reconhecer e distinguir os diferentes recursos tecnológicos existentes (hardware e software), conseguindo analisar criticamente e tomar decisões quanto à sua escolha e utilização contextualizadas ao currículo; Relacionar as informações obtidas pela informática com o cotidiano; Investigar novas formas de utilização dos tablets; Compreender o potencial pedagógico de recursos das TICs no ensino e na aprendizagem nas escolas; Planejar estratégias de ensino e de aprendizagem integrando recursos tecnológicos disponíveis nos tablets e criando situações de aprendizagem com condições para que os alunos construam o conhecimento, a criatividade, o trabalho colaborativo e resultem efetivamente na construção dos conhecimentos e habilidades esperados em cada série; Utilizar as TICs na prática pedagógica, promovendo situações de ensino que aprimorem a aprendizagem dos alunos; Planejar e desenvolver o Projeto de utilização dos tablets na sala de aula.

Para atender todos os objetivos, o curso de formação foi dividido em 4 blocos: TIC $_{S}-$ Fundamentação Básica e teórica do uso dos tablets; Tablet- Recursos Básicos; TabletRecursos Pedagógicos e pesquisas e Tablet - Recursos Avançados.

A avaliação foi de forma processual e com acompanhamento das atividades desenvolvidas nos encontros presencias, bem como no ambiente virtual de aprendizagem.

Apesar de o público estimado ser de 3.051, apenas 1372 se inscreveram no curso de formação. E deste montante, 868 nunca compareceram no ambiente virtual de aprendizagem do curso, e 414 desistiram. Somente 90 professores concluíram o curso em todo o Distrito Federal. E Especificamente, em Ceilândia, cidade do estudo, foram 10 professores concluintes $^{12}$, equivale a $11 \%$ do total. Esse quadro, exposto pelos números, traz consigo

\footnotetext{
${ }^{12}$ Esses dados foram coletados em uma visita a EAPE, repassados pela GEAD- Gerência de Educação a Distância, setor responsável pelo curso.
} 
algumas inferências sobre a receptividade do programa no Distrito Federal, que serão abordados no capítulo referente às análises.

No capítulo seguinte serão apresentados alguns estudos sobre a percepção dos professores quanto aos recursos tecnológicos. 


\section{CAPÍTULO II - PERCEPÇÕES, PROFESSORES E RECURSOS TECNOLÓGICOS}

$\mathrm{O}$ entendimento de percepção a ser trabalhado nesta pesquisa fundamenta-se na conceituação de Abbagnano (2007) complementada com as ideias de Jorge (2011).

Segundo Abbagnano (2007), a percepção possui três significados, indo do aspecto mais geral, passando pelo restrito, até chegar à interpretação dos fatores e condições fundamentais para a construção do termo. Todo esse percurso é reflexo de uma trajetória ao longo do tempo das linhas do conhecimento.

No primeiro significado, o termo percepção se confunde com o de sensação, pois segundo Locke (1978) ${ }^{13}$ : “A P. [percepção] é a primeira faculdade da alma exercida em torno das nossas ideias; por isso, é a primeira e mais simples ideia a que chegamos por meio da reflexão.” (apud ABBAGNAMO, 2007, p.753). Essa percepção é vista como pura, simples e passiva em relação ao objeto/fenômeno.

No segundo significado, o termo "expressa o ato cognitivo objetivo, que apreende ou manifesta um objeto real determinado (físico ou mental)." (ABBAGNAMO, 2007, p.753). A distinção entre sensação e percepção é relativizada e o termo sensação aproxima-se da ideia defendida inicialmente por Locke (1978). O termo percepção traz consigo um caráter ativo, pois é abordado como "um ato complexo que inclui uma multiplicidade de sensações, presentes e passadas, e também a sua referência ao objeto, ou seja, um ato judicativo." (ABBAGNAMO, 2007, p.754). Para Bergson (1970), ${ }^{14}$ a percepção pura é a seleção dentre tantas imagens, que delimitam as necessidades do objeto/fenômeno em questão. Sintetizando, o segundo significado é "o ato pelo qual a consciência "apreende" ou "situa" um objeto, e esse ato utiliza certo número de dados elementares de sensações.” (ABBAGNAMO, 2007, p.754).

Finalmente, o terceiro significado ao termo percepção a compara como a interpretação dos estímulos, a construção dos seus significados. Esse conceito está respaldado por diversas teorias psicológicas contemporâneas, feitas por generalizações experimentais no intuito de evidenciar, de forma pormenorizada, fatores ou condições fundamentais que influenciam esse ato. Dois grupos se distinguem ao focar as condições objetivas e subjetivas. O primeiro

\footnotetext{
${ }^{13}$ John Locke - Filósofo inglês, considerado um dos líderes da doutrina filosófica conhecida como empirismo e um dos ideólogos do liberalismo e do iluminismo. Retirado de http://www.suapesquisa.com/biografias/john_locke.htm. Acesso em 12 de fev. 2014.

${ }^{14}$ Henri Louis Bergson - Filósofo e diplomata francês, um marco na filosofia moderna com suas ideias fundamentais para o desenvolvimento, baseada na consciência, cultura e conexões de vida do seu tempo. Retirado de http://educacao.uol.com.br/biografia/henri-bergson.jhtm. Acesso em 12 de fev.2014.
} 
concentra-se na totalidade do objeto ou do campo observado, pois as partes isoladas não apresentam as mesmas características e privilegiam o aspecto objetivo da percepção. Enquanto que o segundo grupo concentra-se no aspecto subjetivo da percepção e destacam a predisposição do sujeito ao objeto/fenômeno. Para esse grupo

O fato fundamental é que estar disposto para certo estímulo e para certa reação a um estímulo facilita $o$ ato de perceber e possibilita a sua realização com maior prontidão, energia ou intensidade. A disposição, em outras palavras, é um processo seletivo (IV\Q determina preferências, prioridades, diferenças qualitativas ou quantitativas naquilo que se percebe; não é diferente do próprio processo perceptivo, nem é um mecanismo inato ou prefixado, mas um esquema variável aprendido ou construído, ainda que nem sempre voluntariamente. (ABBAGNAMO, 2007, p.755).

Algumas características sobressaem como a da percepção não como um conhecimento exaustivo de um objeto, mas uma interpretação provisória. E por ter esse caráter provisório, a percepção é um tema que desperta interesse em diferentes tempos e áreas do conhecimento.

Épocas diferentes, avanços com o passar do tempo e pontos de vistas diversos acerca da percepção podem ser percebidos pela evolução dos conceitos. E em uma linguagem simples e clara o termo adotado nesta pesquisa apoia-se no terceiro significado por retratar um avanço para o fenômeno percepção.

$\mathrm{O}$ ambiente ao redor dos seres e o ambiente interno juntamente dos seus pensamentos geram energias físicas que se afetam e repassam percepções dos eventos circundantes. Segundo Jorge (2011) “a percepção que se tem do mundo está longe de ser perfeita.”. Pois nossa capacidade perceptiva capta esse mundo exterior por meios dos órgãos dos sentidos: olfato, paladar, tato, audição e visão, nos quais são processados e interpretados pelo cérebro com base em experiências anteriores. Essa interpretação necessita da integração de vários sentidos juntos para atuar na percepção. Para Jorge (2011), o ato perceptivo possui dois componentes fundamentais: a captação e a integração significativa para compor o ato perceptivo.

Esses componentes tornam as percepções objetivas pelas sensações e subjetivas devido à integração significativa que está ligada pelas experiências na consciência da pessoa. Tais elementos estão em destaque no terceiro significado.

A percepção envolve captar e participar das qualidades objetivas de algum fenômeno misturadas aos elementos da memória, do raciocínio realizado, da emoção sentida, e essas qualidades objetivas dos sentidos como filtros da alma também se misturam aos elementos subjetivos de cada indivíduo [...] a percepção se refere ao produto dos processos psicológicos, implicando 
significados, relações, contextos, julgamentos, experiências passadas, memória. (JORGE, 2011, pág. 13).

Diante dessas reflexões, a percepção dos professores a ser analisada nesta pesquisa tenta captar as qualidades, afetividades, julgamentos, expectativas, vivências numa experiência local e temporal, incentivando olhares diferenciados quanto aos programas propostos, bem como, do comportamento dessa classe frente aos recursos tecnológicos no âmbito escolar, refletida pelos níveis de aceitação ao Tablet Educacional, nosso objeto de estudo.

No método empírico, a percepção é associada ao conhecimento que é visto como o resultado de experiências captadas pelos sentidos (Jorge, 2011). O sujeito torna-se autor do seu próprio conhecimento através dessas experiências. Além das experiências, outro fator que influencia a percepção é o grau de cultura em que esse usuário está envolvido. Afirmativa constatada segundo Oliveira et al. (2014) que analisou a percepção de um professor e seus alunos acerca da tecnologia disponibilizada pelos livros eletrônicos e "Los resultados demuestran que la percepcion de los usuarios de los libros de texto eletronicos depende de la cultura institucional en la que están inmersos." ${ }^{15}$ (OLIVEIRA, CAMACHO, GISBERT, 2014). Esse estudo pode exemplificar a influência dos sistemas culturais no ato de perceber e que Jorge (2011) já apontava: “Quando o observador tem no repertório informações e mesmo reflexão sobre esses significados culturais, então a sua percepção e leitura da obra serão modificadas, e certamente, os sentidos, ampliados e enriquecidos.” (JORGE, 2011, p.15).

Ao longo do tempo, a maneira de pensar a percepção ganha novos estudos, segue linhas do conhecimento, tais como o empirismo, o intelectualismo que veem na percepção a função de "ser a atividade que soma e junta partes numa síntese, compondo o objeto percebido" (p.45) e por último, a fenomenologia. "Para a teoria fenomenológica do conhecimento, a percepção é considerada originária do conhecimento humano e formada por uma estrutura diferente daquele pensamento abstrato com ideias.” (JORGE, 2011, p.43).

Toda essa trajetória levanta diversas abordagens, mas que apontam as percepções como "os resultados dos processos psicológicos da significação e memória das experiências vividas, que organizam e integram as sensações." (JORGE, 2011, p.49).

Cysneiros (1996) aponta que as experiências vividas ou mesmo conhecidas influenciam na maneira de perceber um fenômeno: "Las expectativas de algunos docentes de las escuelas públicas están dirigidas hacia la enseñanza profesionalizante de la informática.

\footnotetext{
15 Os resultados mostram que a percepção dos usuários de livros de texto eletrônicos dependem da cultura institucional em que estão inseridos. (tradução nossa)
} 
Esta fue una de las primeras constataciones hechas por nosotros [iii]." ${ }^{16}$ (CYSNEIROS, 1996, p.48). Essa constatação foi aferida, pois os mesmos ainda não haviam tido experiências com as tecnologias em questão, mas tinham conhecimento acerca das práticas nas escolas privadas.

Com o avanço dos recursos tecnológicos e da modernização das técnicas, os estudos sobre a percepção também evoluem e tornam-se um fator investigativo sobre os fenômenos no mundo e o conhecimento acerca dos mesmos e do ser humano em si próprio. Pois, conforme Lévy (1956), essa relação é um processo social, uma atividade multiforme de grupos humanos com as tecnologias e que o sucesso ou não advém da atividade sobre a técnica.

A qualidade do processo de apropriação (ou seja, no fundo, a qualidade das relações humanas) em geral é mais importante do que as particularidades sistêmicas das ferramentas, supondo que os dois aspectos sejam separáveis. (LÉVY, 1956, p.28)

Diante desse cenário, a abordagem desta pesquisa é restrita ao contexto educacional, à inserção das TDIC, mais especificamente, o Tablet Educacional e a relação desta tecnologia com o professor.

No capítulo seguinte, tratarei sobre o termo receptividade, também um dos cernes desta pesquisa.

\footnotetext{
${ }^{16}$ As expectativas de alguns professores de escolas públicas são voltadas para o ensino profissionalizante da informática. Esta foi uma das primeiras observações feitas por nós. (tradução nossa)
} 


\section{CAPÍTULO III - A RECEPTIVIDADE AOS RECURSOS TECNOLÓGICOS}

A reflexão sobre a receptividade aos novos meios tecnológicos pressupõe possibilidades de aceitação ou não, bem como aos conceitos de "apocalíptico" e "integrado", do início dos anos 70 de Umberto Eco. Reavivar tais termos objetiva refletir sobre a importância dos mesmos, suas contraposições para avançar em direção às ações integradas desses conceitos.

A resistência ao novo, exaltado por uma cultura de massa, reflete uma série de opções culturais do indivíduo. Para os apocalípticos, a cultura de massa é a anticultura (ECO, 1970).

O pior testemunho a favor de uma obra é o entusiasmo com que a massa se volta para ela... Todos os grandes empreendimentos da história foram até agora fundamentalmente frustrados e privados de êxito efetivo, porque a massa se interessou e se entusiasmou por eles [...] (ECO, 1970.p. 17).

Há um discurso "apocalíptico" e "integrado" ante as novas tecnologias e suas possíveis mudanças nas estruturas educacionais que vem sempre acompanhado por este tom de entusiasmo. É um fenômeno eruptivo do contexto histórico que exibe vivências e ações que refletem ora o discurso apocalíptico, ora o discurso integrado e emerge com a chegada de novas tecnologias nas salas de aulas. A reação de muitos professores em relação a esse fenômeno são ideias e ações que podem remeter aos apocalípticos, ao mencionar os receios dessas tecnologias na criatividade, na sensibilidade dos seus alunos, ou que essa cultura massifica, não levando em consideração as diferenças culturais, ou ainda categorizando como mais um desestímulo pelo viés de lazer e entretenimento que elas ensejam; ou remetem aos integrados, que vislumbram nas tecnologias algo novo capaz de permitir o acesso a novos conhecimentos, à cultura por meio da Internet e seus recursos.

Papert (2008) ao propor uma viagem a um grupo de professores sobre as mudanças ocorridas em um século atrás na sua profissão faz a seguinte constatação sobre o sistema escolar: "ele mudou, mas não a ponto de alterar substancialmente sua natureza." (PAPERT, 2008, p.18). E a partir dessa simulação, ele menciona os Schoolers e os Yearners, surge também uma dicotomia que se assemelha ao de Eco (1970). Os Schoolers seriam os "apocalípticos", que não acreditam em megamudanças e que a estrutura escolar não necessita dessas várias tecnologias. Podem "até aceitar que uma Máquina do Conhecimento possa ampliar as possibilidades do aprender [...] No entanto, não consideram isso significativamente 
diferente de uma boa explicação [...]" (PAPERT, 2008, p.27). Ou ainda, podem até fazer uso das tecnologias, mas em uma "inovação conservadora" (CYSNEIROS, 1996).

Na via contrária, encontram-se os "integrados" que, segundo ECO (1970), percebem uma época de expansão da área cultural devido à disposição dos bens culturais desde o jornal, televisão, rádio, cinema, histórias em quadrinhos a computadores, celulares, internet, entre outros aparatos que tornam mais leve e agradável à absorção de noções e a recepção de informações. O mesmo acontece com os Yearners, categoria citada por Papert (2008) que anseiam por algo diferente na forma de ensinar e aprender. E veem na Máquina do Conhecimento (o computador) uma forma de driblar a estrutura escolar com a criação de programas alternativos. Essa aprendizagem advinda pelo computador é considerada por Papert (2008) uma transição mais tranquila, gradual e próxima da aprendizagem anterior à escola para aquela ensinada na escola. Os argumentos positivos, levantados pelos Yearners, são o acesso à informação por uma grande parcela da população que sempre esteve à margem das informações; bem como lhe darem voz e identidade, pois os recursos atuais propiciam a criação, divulgação e interação da sua realidade, do seu olhar sobre os acontecimentos. As TDIC contribuem para expansão da comunicação que ultrapassa a periferia circundante do indivíduo e é capaz de influenciar a sociedade capitalista para uma sociedade mais democrática, de fato.

Em manter-se distante das TDIC ou aproximar-se delas, qual o papel do professor? Um professor "apocalíptico" / Schooler que resiste a inserção dos recursos tecnológicos em suas aulas por perceber mais transtornos que verdadeiro conhecimento? Ou um professor “integrado" / Yearner que aposta nesses recursos para implementar suas aulas, mesmo não sabendo ao certo como lidar com os mesmos pedagogicamente?

Não há aqui respostas corretas, pois conforme Castells (2011) ao abordar as várias transformações sociais advindas com as tecnologias da informação, desde o declínio dos movimentos de trabalhadores, incorporação das mulheres no campo de trabalho, atividades tornando-se globais e mais informacionais a inserção de uma língua universal digital, essas e outras mudanças tão confusas e incontroladas surgiram e estão surgindo deixando o indivíduo perturbado. Esse contexto, configurado por Castells (2011) como a Rede, coloca o ser em uma inquietude na sua identidade: "Nossas sociedades estão cada vez mais estruturadas em uma oposição bipolar entre a Rede e o Ser." (CASTELLS, 2011, p.41, formatação itálico do texto original). Ao mencionar sociedades, a amplitude dessa inquietação espalha-se e muitos estão envolvidos nesta bipolaridade. 
De acordo com Eco (1970), “a massa, superadas as diferenças de classe, é, agora, a protagonista da história, e, portanto sua cultura, a cultura produzida para ela, e por ela consumida, é um fato positivo.” (ECO, 1970, p. 18).

Ora, para os "apocalípticos" essa afirmação é falsa, pois essa cultura é produzida para a massa e consumida pela mesma, não havendo a verdadeira autonomia nesta produção cultural pelos meros usuários. No entanto, as novas TDIC contribuem para uma cultura pela massa, pois um novo consumidor, ainda que aprendiz em relação à TDIC, aparece mais autônomo, mais individual e mais atento a suas reais necessidades. "Quer dizer, a era industrial pode já estar em processo de substituição por uma nova fase na história humana, e o homem industrial, quaisquer que sejam as suas características, pode estar evoluindo rumo a algo diferente e superior - rumo ao homem tecnológico.” (FERKISS, 1976, p. 58).

AL-SENAIDI and POIROT (2009) apontam mais resistência às TDIC no contexto educacional do que uma aceitação em Omã, estado da Arábia. Constatou-se que há um grau moderado de barreiras à aplicação das Tecnologias de Informação e Comunicação (TICs) nas práticas de ensino pelos professores. As implicações advindas desse estudo são: maior necessidade de apoio institucional, formação técnica e tempo para os professores se inteirarem com os conhecimentos e competências nesta área.

Há cerca de três décadas, as TDIC são temas de estudos que buscam associar e investigar as experiências e expectativas da utilização das tecnologias no contexto educacional. (GINZBERG 1981, SZAJNA e SCAMELL 1993, BHATTACHERJEE 2001, STAPLES et al. 2002 apud BROWN, VENKATESH e GOYAL, 2012). É possível identificar diversas teorias que buscam fundamentar o comportamento perante as novas tecnologias. Uma das mais conhecidas e utilizadas é o modelo de aceitação tecnológica (TAM), este modelo é utilizado em pesquisas em consonância com outras teorias.

Apesar da teoria de aceitação ser reconhecida, há pouca investigação acerca das crenças em relação a tecnologias, teórica e empiricamente. (BROWN, VENKATESH e GOYA, 2012). Diante dessa realidade, estudos acerca das percepções e crenças dos professores frente aos recursos tecnológicos e o processo educacional se mostram pertinentes. O que se leva a questionar quantos aos desafios na inserção da tecnologia educacional nas salas de aulas. Há, de fato, resistência em repensar atitudes e práticas pedagógicas no processo de ensino e aprendizagem?

Segundo Cassirer (1961 apud CARNEIRO, 2005, p.104), as raízes para "a resistência à não-utilização do potencial visual e narrativo da televisão nos programas instrucionais de TV", residem na resistência da educação às emoções. Dentro do processo educacional dito 
racional, emoções desequilibram e perturbam, ainda que nelas se reconheça estímulo essencial à educação. "Cabe abrir a educação às dimensões do imaginário, do cultural, do afetivo, e entender ensino-aprendizagem como diálogo, interação, construção de conhecimentos." (CARNEIRO, 2005, p.104).

Carneiro (2007) alia essa resistência à falta de conhecimento da tecnologia e de experimentação de novas formas de ensino com as mesmas. Infere-se que para aqueles que aceitam o desafio de lidar com a tecnologia é necessário um suporte contínuo nos primeiros anos, a fim de subsidiá-los na inovação e assimilação dessa tecnologia. (CYSNEIROS, 1996).

A busca de conhecimentos empíricos e científicos acerca dessa temática, a divulgação de ações exitosas com as TDIC no meio educacional, a formação continuada para o uso das TDIC são temas que renovam sua importância a cada meio tecnológico, pois para o professor tecnológico ou não, o "seu destino não é o de tornar-se escravo de suas próprias criações ou o de se perder em alguma e nova proeza social, que peça uma rendição total de sua individualidade, mas o de explorar plenamente todas as complexidades de seu eu individual." (FERKISS, 1976, p. 186).

Kopcha (2012) adverte sobre a necessidade de novas pesquisas:

Given the increasing presence of technology in today's classrooms, there is a current and pressing need for research on situated professional development in K12 settings that improves on these known issues and advances our understanding of the relationship between those activities, teachers' perceptions of the barriers, and ultimately teachers' instructional practices with technology. (KOPCHA, 2012, p.11). ${ }^{17}$

$\mathrm{Na}$ busca de contribuir com as pesquisas sobre aceitação e comportamentos dos professores com os meios tecnológicos no contexto escolar e dos conhecimentos já existentes, essa pesquisa lança seu olhar à receptividade do professor através dos níveis de aceitação ao Tablet Educacional, com o auxílio da Teoria Unificada de Aceitação e Uso da Tecnologia, que será o foco do próximo capítulo.

\footnotetext{
17 Dada a crescente presença da tecnologia nas salas de aula de hoje, há uma necessidade atual e premente para a pesquisa sobre o desenvolvimento profissional situado em ambientes K12 que melhora sobre estas questões conhecidas e avança nossa compreensão da relação entre essas atividades, percepções das barreiras dos professores, e, finalmente, as práticas de ensino dos professores com a tecnologia. (tradução nossa)
} 


\section{CAPÍTULO IV - TEORIA UNIFICADA DE ACEITAÇÃO E USO DA TECNOLOGIA (UTAUT): A TEORIA EM DESTAQUE}

Desenvolvida por Venkatesh et al. (2003), a Teoria Unificada de Aceitação e Uso da Tecnologia (UTAUT) surge com a intenção de ampliar os estudos acerca da temática aceitação e uso das tecnologias. Sua estrutura possui elementos significativos de oito modelos que como a UTAUT procuram evidenciar fatores que influenciam a intenção de uso até ao uso real da tecnologia da informação.

Desse modo, esse capítulo descreve os pontos principais para a elaboração dessa teoria por meio do quadro abaixo que sintetiza os modelos utilizados, com as denominações e respectivas siglas, seus desenvolvedores, objetivos e aspectos relevantes de cada um. Esse retrospecto e a justificativa para a construção de uma nova teoria são expostos; logo após, destaque aos constructos presentes na UTAUT e suas características.

Quadro 2 - Modelos de uso e aceitação das tecnologias

\begin{tabular}{|c|c|c|c|}
\hline Modelo & $\begin{array}{c}\text { Desenvolvido } \\
\text { por: }\end{array}$ & Objetivo/ Foco & $\begin{array}{l}\text { Aspecto } \\
\text { relevante }\end{array}$ \\
\hline $\begin{array}{l}\text { Teoria da Ação } \\
\text { Racional (TRA) }\end{array}$ & $\begin{array}{l}\text { Fishbein e Ajzen } \\
\text { (1975) }\end{array}$ & $\begin{array}{l}\text { Determinar o } \\
\text { comportamento individual } \\
\text { pelas intenções de } \\
\text { comportamento. }\end{array}$ & $\begin{array}{l}\text { Atitude definida } \\
\text { por sentimentos } \\
\text { positivos ou } \\
\text { negativos }\end{array}$ \\
\hline $\begin{array}{l}\text { Modelo de } \\
\text { Aceitação da } \\
\text { Tecnologia (TAM) }\end{array}$ & Davis (1989) & $\begin{array}{l}\text { Avaliar o comportamento } \\
\text { de utilização da tecnologia, } \\
\text { analisando as atitudes para } \\
\text { usar os SI. }\end{array}$ & 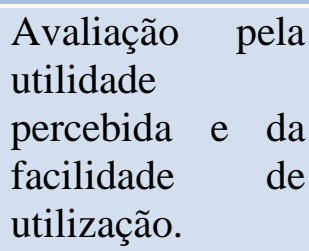 \\
\hline $\begin{array}{l}\text { Modelo } \\
\text { Motivacional } \\
(\mathrm{MM})\end{array}$ & $\begin{array}{l}\text { Vallerand } \\
\text { (1997) }\end{array}$ & $\begin{array}{l}\text { Trabalhar com as teorias } \\
\text { motivacionais para explicar } \\
\text { o comportamento dos } \\
\text { indivíduos. }\end{array}$ & $\begin{array}{l}\text { Motivação } \\
\text { intrínseca } \\
\text { extrínseca }\end{array}$ \\
\hline $\begin{array}{l}\text { Teoria do } \\
\text { Comportamento } \\
\text { Planejado (TPB), }\end{array}$ & Ajzen (1991) & $\begin{array}{l}\text { Ampliar a TRA com a } \\
\text { inclusão do constructo } \\
\text { controle do comportamento } \\
\text { percebido como um } \\
\text { determinante da intenção e }\end{array}$ & $\begin{array}{l}\text { Controle } \\
\text { comportamental } \\
\text { percebido. }\end{array}$ \\
\hline
\end{tabular}




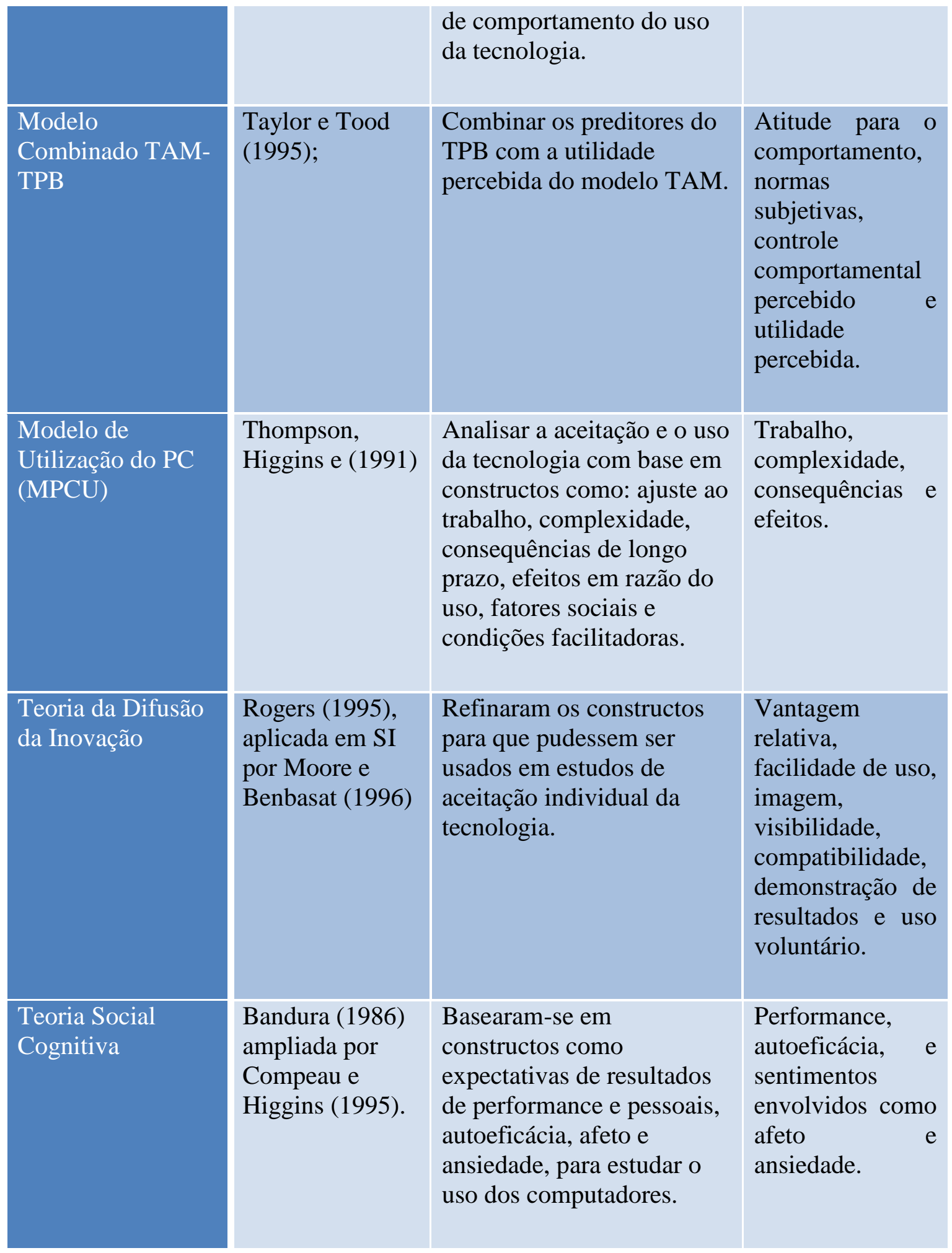

Fonte - Quadro-síntese produzido pela pesquisadora (2013)

O modelo mais utilizado nas pesquisas de aceitação do usuário é o modelo de aceitação de tecnologia (TAM; DAVIS, 1989). Ele surge como uma adaptação da Teoria da Ação Racional (TRA; FISHBEIN \& AJZEN, 1975), para explicar especificamente aceitação do computador. TAM e suas derivações (VENKATESH e BALA, 2008 e VENKATESH e 
DAVIS, 2000) eram frequentemente usadas como ferramentas de pesquisa para investigar a aceitação de inovações tecnológicas pelos usuários finais. No entanto, esse modelo previa a aceitação da tecnologia em $40 \%$ dos casos investigados (VENKATESH e DAVIS, 2000). Esta lacuna da TAM e das demais teorias levaram ao desenvolvimento da Teoria Unificada de Aceitação e Uso da Tecnologia (UTAUT; VENKATESH e MORRIS e DAVIS e DAVIS, 2003), integrando elementos centrais de oito modelos de aceitação de tecnologia diferentes, incluindo TAM.

O modelo UTAUT de aceitação da Tecnologia da Informação e Comunicação foi desenvolvido a partir dessas teorias. Esse modelo unificado apresenta quatro determinantes diretos da intenção e uso da Tecnologia da Informação e Comunicação nas organizações, que consequentemente influenciam no comportamento de uso. São eles:

1. Expectativa de Performance: esse constructo define como o grau em que o indivíduo acredita que ao usar o sistema/recurso ele terá ganhos de performance em seu trabalho. Ele é baseado em cinco teorias: TAM e TPB; MM; MPCU; IDT e SCT.

2. Expectativa de Esforço: segue semelhanças de três modelos anteriores (TAM/TAM2, MPCU e IDT) e que relaciona o grau de facilidade associado ao uso do sistema/recurso explorado.

3. Influência Social: é definida como o grau de percepção do indivíduo em relação aos demais quanto à crença destes para com a necessidade de uma nova tecnologia ser usada ou não (VENKATESH et al., 2003, p. 451). Esse constructo é mais significativo apenas em caso de voluntarismo, ou seja, quando o uso da tecnologia é da vontade do usuário, não sendo o mesmo no caso do seu uso mandatório.

OBS: O constructo, Influência Social, foi analisado nesta pesquisa, pois a adesão ou não ao projeto foi um ato voluntário do professor. Aqueles que aceitaram participar do projeto, automaticamente iriam participar da formação do Estado.

4. Condições Facilitadoras: é descrito como o grau pelo qual o indivíduo acredita que existe uma infraestrutura organizacional e técnica para suportar o uso do sistema (VENKATESH et al., 2003, p. 453).

Há ainda quatro fatores moderadores (características pessoais dos usuários que possuem papel de moderador), que podem influenciar na aceitação e uso dessa tecnologia de 
forma indireta. Eles estão vinculados a dados sociodemográficos, que também compõe a estrutura desse modelo. São eles:

1. Gênero;

2. Idade;

3. Experiência;

4. Voluntariedade de uso (neste caso, verifica-se que grau o uso da tecnologia é voluntário, ou obrigatório).

Todos os constructos possuem efeitos diretos e positivos. E cada qual influencia o constructo Intenção de Uso da tecnologia, que por sua vez, também possui os mesmos efeitos no comportamento de Uso.

Esses constructos finais contemplam:

$>$ Intenção de Uso: avalia o grau que o indivíduo planeja utilizar a tecnologia ou o sistema, em um futuro próximo.

$>$ Comportamento de Uso ou apenas Uso: diagnostica a utilização real da tecnologia ou do sistema pelo indivíduo. 
Segue um mapa conceitual ${ }^{18}$ que exemplifica a teoria escolhida:

Figura 2- Mapa Conceitual da Teoria Unificada de Aceitação e Uso da TecnologiaUTAUT

adaptado de Venkatesh et al. (2003, p.447)

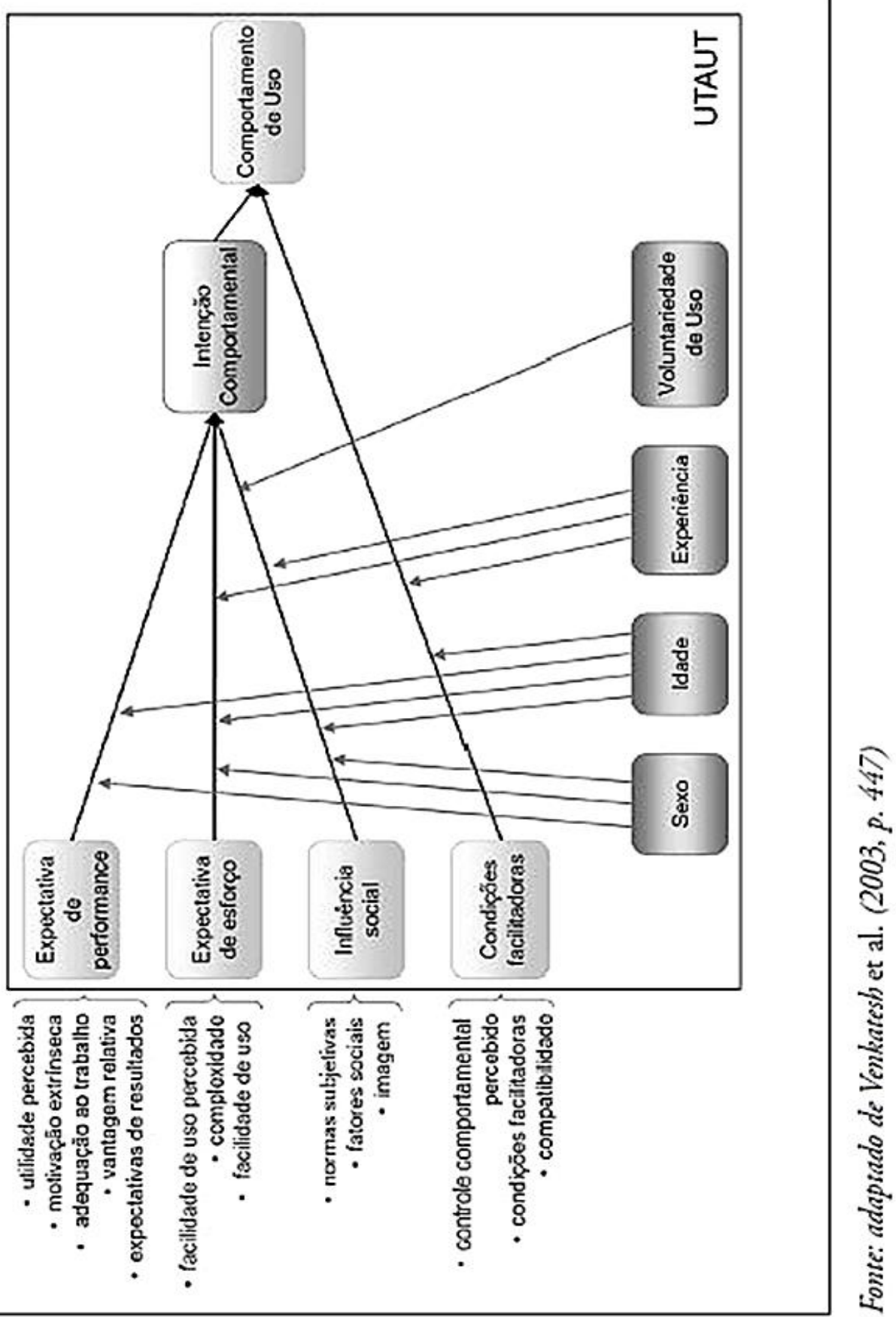

\footnotetext{
${ }^{18}$ Fonte - Imagem retirada do site: http://www.scielo.oces.mctes.pt/img/revistas/egg/v17n1/17n1a03f1.jpg, em
} 1 de outubro de 2013 
A figura acima apresenta o modelo UTAUT e retrata a relação de construções importantes em termos de intenção de uso e comportamento. Teoria que é base da nossa pesquisa.

Segundo Jenkins (2009) quanto mais a fundo você investiga, mais segredos aparecem, então, convido-os a conhecer a metodologia desta pesquisa, próximo capítulo, e quem saber desvendar alguns segredos. 


\section{CAPÍtULLO V - A METOdOLOGIA}

Neste capítulo são apresentados os processos sistemáticos da pesquisa com os instrumentos utilizados para a coleta e análise dos dados quantitativos e qualitativos na busca de evidenciar e alcançar os objetivos desta pesquisa:

Objetivo geral:

Analisar as percepções dos professores cursistas do Projeto Educação Digital e sua receptividade ao Tablet Educacional como ferramenta pedagógica.

Objetivos específicos:

1. Investigar o nível de aceitação dos professores ao recurso tecnológico no âmbito escolar, o Tablet Educacional;

2. Identificar as expectativas dos professores em relação à formação ofertada para o uso pedagógico do Tablet Educacional;

3. Analisar as expectativas dos professores em relação ao Tablet Educacional, seus recursos na execução de tarefas pedagógicas;

4. Conhecer a necessidade desse recurso tecnológico no âmbito escolar;

Optou-se pelo estudo de caso, pois possibilita a pesquisadora aprofundar na exploração do Projeto Educação Digital proposto pelo MEC, no qual envolve um número amplo de professores em um contexto específico da realidade, o Distrito Federal. E pela abordagem mista, na qual permite trabalhar com dados quantitativos e qualitativos, e com suas análises aprofundar na questão desse estudo.

Logo, percorramos juntos os trajetos desta pesquisa.

\subsection{Abordagem Metodológica Mista}

Nesta pesquisa, para se conseguir uma compreensão mais abrangente dos dados quantitativos e qualitativos, adotou-se a integração dos métodos já que "Nem sempre um único método ao longo da investigação é suficiente para orientar todos os procedimentos a serem desenvolvidos ao longo da investigação.” (GIL, 2010, p.15).

Em busca da orientação com precisão e objetividade ao nosso estudo e devido à complexidade do tema, foi adotado o método Misto (GIL, 2010). O método quantitativo tornou-se apropriado por sua característica em atuar nos níveis de realidade a partir da identificação e apresentação dos dados indicadores e tendências observáveis quanto à 
aceitação e receptividade ao Tablet Educacional, por meio de variáveis e inferências a partir de uma amostra de professores envolvidos no projeto Educação Digital. A partir dos padrões encontrados nos dados quantitativos, o método qualitativo une-se à pesquisa na busca de reunir valores, crenças, atitudes e opiniões acerca do tema do estudo. Esse método possibilita outras explorações voltadas aos detalhes subjetivos dos pesquisados e que enriquecem o estudo em sua totalidade.

No decurso das informações, será possível perceber que essa combinação tornou-se pertinente à pesquisa.

\subsubsection{Abordagem Quantitativa}

$\mathrm{Na}$ abordagem quantitativa, esta pesquisa pautou-se na Teoria Unificada de Aceitação e Uso da Tecnologia (UTAUT) no intuito de analisar mediante variáveis a percepção e a receptividade dos professores quanto ao Tablet Educacional. A adequação da teoria se deve ao fato da mesma procurar em seu modelo explicitar as intenções dos usuários para utilizar um determinando sistema de informação ou uma tecnologia. Nesse momento, o foco do modelo volta-se para a aceitação do usuário. Há ainda variáveis que procuram analisar o comportamento desses usuários ao uso do sistema ou da tecnologia em questão, ou seja, possui a preocupação quanto ao uso. Para mensurar as intenções e os comportamentos, a teoria possui 4 constructos determinantes: Expectativa de Desempenho, Expectativa de Esforço, Influência Social, Condições Facilitadores. Possui, ainda, Fatores Moderadores e duas variáveis dependentes: Intenção de Uso e Comportamento de Uso, que relacionam entre si, conforme mencionado no capítulo 4. Essa teoria é nova e pouco utilizada nos estudos voltados à área educacional e ao contexto brasileiro. No entanto, sua estrutura é flexível e oportuno ao nosso contexto de pesquisa.

Neste estudo, a atenção foi direcionada aos 4 constructos determinantes e nos fatores moderadores para analisar a Intenção de Uso dos professores quanto ao Tablet Educacional. A variável Comportamento de Uso não foi mensurada porque os pesquisados ainda não haviam iniciado a utilização do Tablet Educacional efetivamente. As categorias de cada constructo foram evidenciadas em cada seção do instrumento questionário, a fim de atender nossos objetivos. As assertivas contidas foram adaptadas para o nosso contexto, contudo a análise e a interpretação dos dados coletados seguiram a teoria original. 


\subsubsection{Abordagem Qualitativa}

$\mathrm{Na}$ abordagem qualitativa, a coleta de dados consistiu em obter as expectativas e os pontos de vista dos participantes desta pesquisa de forma subjetiva através das suas emoções, prioridades, experiências, significados para o Tablet Educacional enquanto ferramenta pedagógica. O cunho dessa abordagem mostrou-se conveniente após as análises dos dados quantitativos em que alguns valores apresentaram-se divergentes à fase exploratória, fato que me conduziu a novas análises. Nesse momento, aproximar-se do nosso pesquisado, e a partir dessa interação, aperfeiçoar nosso estudo acerca dos temas da pesquisa (aceitação e receptividade) foi necessário para a ampla compreensão desses assuntos.

$\mathrm{Na}$ busca de captar tais acepções foram elaboradas perguntas que mantiveram temas relacionados ao questionário e que foram aplicadas no formato de uma entrevista semiestruturada com um professor de cada escola em estudo, o que totalizou sete entrevistados. $\mathrm{O}$ intuito foi de acompanhar por meio das entrevistas qualitativas esses casos discrepantes, pois "pode proporcionar insights sobre o motivo pelo qual eles divergiram da amostra quantitativa" (CRESWELL, 2010, p.257). Todo esse processo visa atender aos objetivos da pesquisa em sua plenitude. Os dados coletados por meio desse método foram informações de apoio e complementares às advindas do método quantitativo, recolhidas de forma mais livre, sentida e experimentada pelo nosso entrevistado.

\subsubsection{Estratégia Explanatória Sequencial}

A estratégia explanatória sequencial é voltada para estudos com métodos mistos e mostrou-se mais adequada para atender a exploração de aspectos relevantes e significativos quanto ao tema percepção docente ao Tablet Educacional no âmbito escolar. Essa estratégia exemplifica as fases do nosso estudo, visto que, a base de dados quantitativos desta pesquisa foi reunida, primeiramente, pela Teoria Unificada de Aceitação e Uso da Tecnologia (UTAUT) por meio de um questionário on-line. Na segunda fase, a entrevista serviu como aporte para expandir e aprofundar o entendimento do fenômeno e constituiu o banco de dados qualitativos dessa pesquisa. Segue a Figura 03 do modelo visual proposto por Creswell (2010) e que representa a nossa pesquisa. 
Figura 3-Projeto sequencial ${ }^{19}$

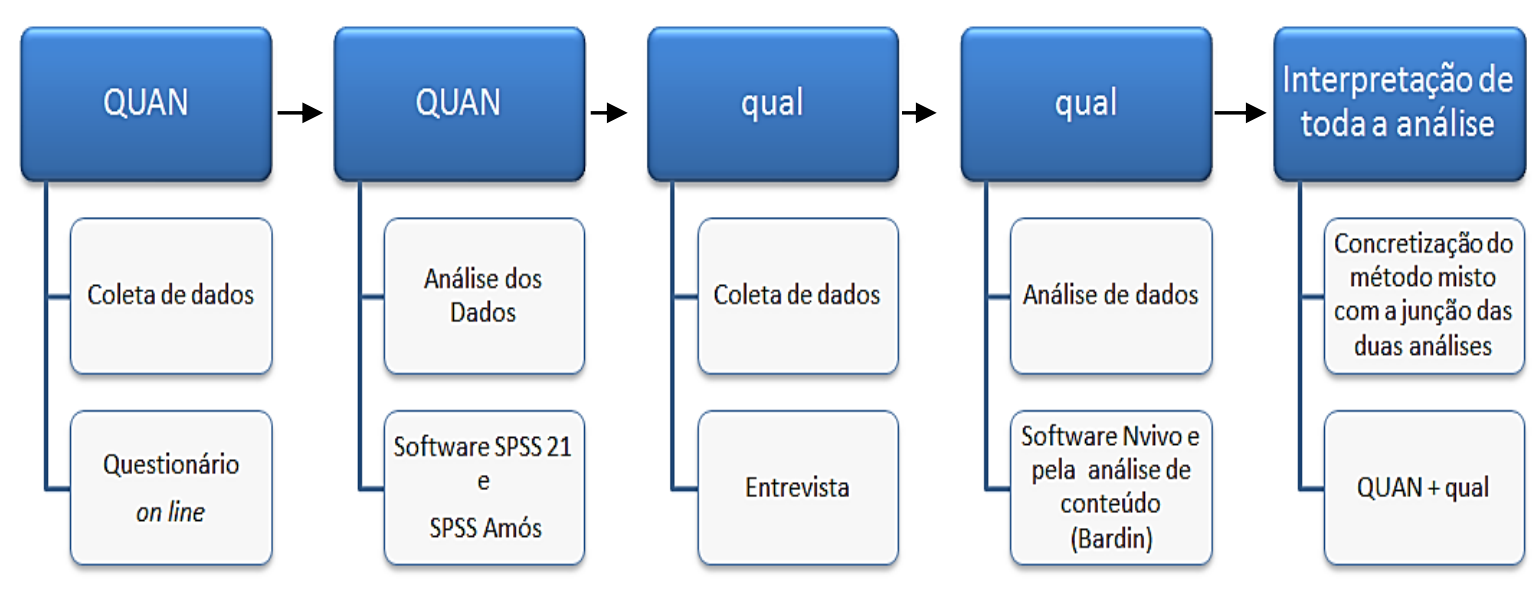

Fonte: Estratégia explanatória sequencial adaptada pela pesquisadora

Pode-se notar na figura 3 que a base quantitativa possui um peso maior em relação à qualitativa e representa o modelo utilizado nesta pesquisa. Essa combinação de dados, tanto quantitativos quanto qualitativos, caracteriza-se como conectados e que todos os caminhos analisados contribuem na investigação e auxiliam no resultado final (CRESWELL, 2010).

Essa estratégia de planejamento adequou-se ao tempo disponível para essa pesquisa, apesar de alguns percalços, como: a incompatibilidade de calendários escolares das instituições: UNB e SEDF. No entanto, o escopo atendeu às expectativas de coleta e análise dos dados.

\subsection{Local da Pesquisa}

A presente investigação foi realizada em Ceilândia - DF, cidade fundada em 1971 e considerada a mais populosa do Distrito Federal. Sua área metropolitana tem cerca de 400 mil habitantes. Como as grandes cidades desse país, ela possui seus contrastes sociais e econômicos. No campo educacional apresenta-se como a maior cidade da região em relação aos números de escolas e de estudantes, totalizando 96 escolas com aproximadamente 95000 alunos.

Nesta localidade há onze escolas com a modalidade de ensino médio, público-alvo do Projeto Educação Digital. Embora esse Projeto seja destinado a todas as escolas de ensino médio, inicialmente, somente sete escolas foram contempladas na região. A escolha não foi

\footnotetext{
${ }^{19}$ Figura adaptada do modelo de Creswell e colaboradores (2003) apud Creswell (2010, p. 246). A figura original encontra-se no site: http://image.slidesharecdn.com/cap10livronovodecreswell-111101125752phpapp01/95/captulo-10-de-creswell-6-728.jpg?cb=1320170305, acesso em 29/01/2015.
} 
aleatória, pois seguiu ao critério estabelecido pelo governo local, no qual a seleção estava condicionada à adoção da escola do programa da semestralidade.

\subsection{A Amostra}

Para esta pesquisa, a amostra refere-se aos professores participantes do curso de formação da Secretaria de Estado de Educação do Distrito Federal para o uso do Tablet Educacional e vinculados à cidade de Ceilândia, que no total são 302 professores participantes. Esse curso é parte integrante do Projeto Educação Digital e responsabilidade do Estado. No DF, os professores que aderissem ao projeto, estavam automaticamente inscritos no curso.

Essa amostra é heterogênea devido à abrangência de serem professores do ensino médio, das diversas disciplinas ofertadas nesse segmento. Sendo que 57\% dos participantes são da área de humanas, com a formação em Arte, Filosofia, História, Espanhol, Geografia e Letras/ Inglês. E 42\% compõem a área de exata: Ciências, Biologia, Matemática, Física, Química e Educação Física. Alguns não responderam esse campo. Quanto à experiência docente, o tempo varia de 1 ano de serviço a 30 anos. Segue o montante selecionado para cada abordagem (quanti e quali).

\subsubsection{Da abordagem quantitativa}

Dos 3.051 professores, montante geral que o projeto visa atender em todo o $\mathrm{DF}$, o universo desta pesquisa perfaz um total de 302 professores ${ }^{20}$ inscritos no curso de formação. Segue as escolas e o quantitativo de cada uma:

Centro de Ensino Médio 02 com 46 inscritos;

Centro de Ensino Médio 03com 70 inscritos;

Centro de Ensino Médio 04 com 58 inscritos;

Centro de Ensino Médio 09 com 16 inscritos;

Centro de Ensino Médio 10 com 41 inscritos;

Centro de Ensino Médio 12 com 42 inscritos e

Centro Educacional 14 com 29 inscritos.

\footnotetext{
${ }^{20}$ Esse dado foi disponibilizado pelo Núcleo de Tecnologia Educacional de Ceilândia, responsável pelo contato e recebimento dos documentos das escolas envolvidas nesta pesquisa.
} 
Esse quantitativo, 302 professores, corresponde à população fonte. Trata-se dos docentes que receberam os instrumentos de investigação e que tinham o livre arbítrio de colaborar com os dados desta pesquisa. No entanto, todos os professores do ensino médio referem-se à população externa, o público-alvo desta pesquisa, pois fazem parte do mesmo contexto da população fonte. Segue organograma explicitando essa relação:

Figura 4- População da Pesquisa

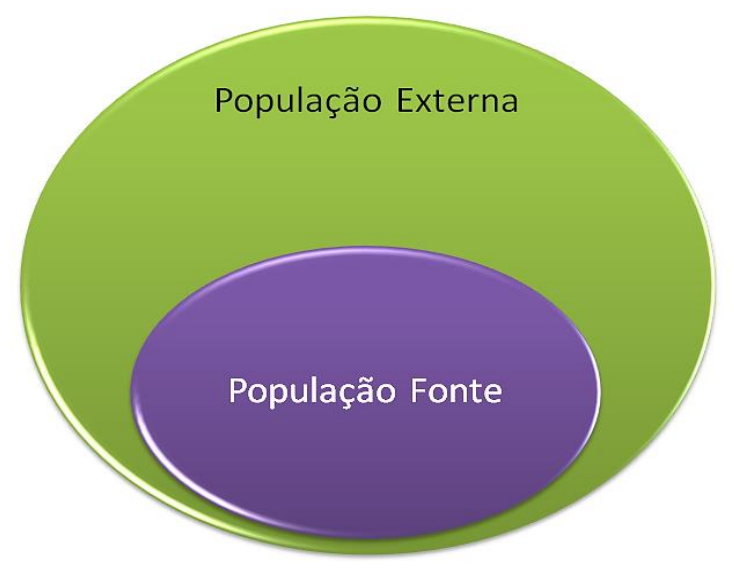

Fonte: Organograma elaborado pela pesquisadora

Os resultados advindos da população fonte dirigem-se a todos (população externa), pois podem auxiliá-los a conhecer a sua própria realidade.

\subsubsection{Da abordagem qualitativa}

A seleção dos professores para esta etapa qualitativa proveio da amostra dos participantes da fase quantitativa. Por meio de e-mails encaminhados a todos os professores participantes, foram selecionados sete professores. Essa seleção foi intencional, pois estava condicionada a ser um participante por escola, para caracterizar uma amostragem por quota. Recebi seis respostas positivas e apenas uma foi por indicação da coordenação da escola, que convidou pessoalmente um professor para essa fase. Dessa amostra, seis participantes eram do gênero masculino, e um, apenas do gênero feminino. Algumas áreas disciplinares desses professores foram identificadas nas diversas respostas dadas: química, matemática e sociologia. 
Figura 5- Relação das Amostras

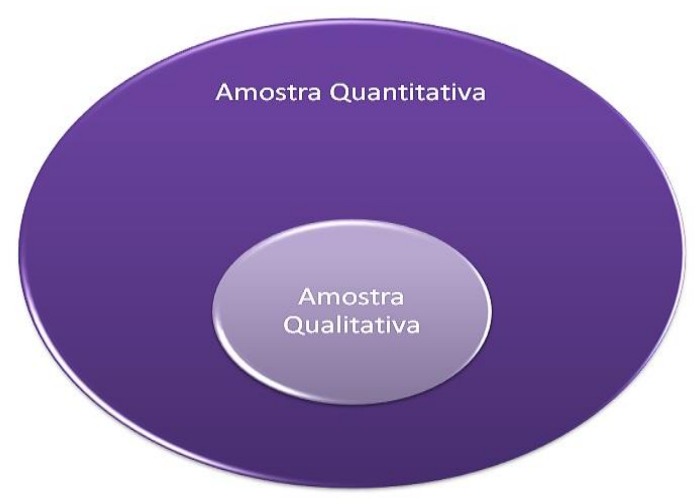

Fonte: organograma elaborado pela pesquisadora

A relação das amostras procura atender os objetivos dessa pesquisa e demonstra a proporção de cada abordagem no contexto desse estudo.

\subsection{Os instrumentos}

Os instrumentos selecionados para alcançar os objetivos desta investigação foram o questionário on-line, principal instrumento, e a entrevista semiestruturada, instrumento complementar. O questionário foi delineado em uma versão preliminar com caráter exploratório e outra versão final após adequações. Tais instrumentos forneceram informações e dados sobre o nosso objeto de estudo que serão expostos nas seções seguintes. Ambos os instrumentos encontram-se no Apêndice (B e C).

\subsubsection{Questionário}

A versão online do questionário, ou seja, survey eletrônico, foi utilizada para atender as peculiaridades da população fonte e alcançar o maior número de participantes; consequentemente, maior levantamento de dados, assim como, apresentar imparcialidade na coleta.

A estruturação do questionário e sua consolidação seguiram algumas etapas:

1. Concepção do questionário a partir do modelo UTAUT e sua formatação em suporte digital, on-line: após compreender cada constructo dessa teoria e suas peculiaridades, buscou-se a construção das assertivas, adequando-se ao contexto brasileiro. Tais assertivas passaram por adequações para atender aos propósitos e condições desta pesquisa. Uma delas consistiu no número de 
assertivas para cada constructo, mas que conservaram a estrutura original (ver Apêndice B). Não foram incluídas assertivas referentes ao constructo Comportamento de Uso devido a nossa população fonte ter recebido o recurso tecnológico em questão, o Tablet Educacional, há pouco tempo e encontrava-se na fase de formação para o uso efetivo desta ferramenta. Impossibilidade então, de mensurar esse constructo no período do estudo. Para a criação de um formulário (questionário) utilizou-se o aplicativo Google Drive com os 26 itens distribuídos em oito seções. Da primeira a sétima seção as questões foram fechadas, finalizando, na oitava seção, com questões abertas. Somente após a conclusão das respostas dos itens de cada seção, era disponibilizada a outra seção. Desta forma, o questionário não ficou cansativo e aparentemente não extenso, pois não tinha o todo disponibilizado integralmente. Todos os itens que compõem nosso estudo tanto os adaptados a essa pesquisa quanto os originais da teoria UTAUT encontram-se no Apêndice B.

2. Validação semântica: O questionário mencionado foi testado por cinco professoras, especialistas nas áreas de português, matemática, educação física, pedagogia e tecnologias em educação. A diversidade nas áreas disciplinares foi proposital para aproximar-se da nossa população fonte já que essa população é composta por professores de todas as disciplinas ofertadas no ensino médio. Essa etapa serviu para uma revisão do instrumento quanto à parte de conteúdo e adequação ao modelo proposto, quanto ao vocabulário e quanto à disposição dos elementos para melhor compreensão das questões pelos sujeitos da pesquisa. A contribuição desse grupo heterogêneo foi de fundamental importância para a finalização dessa etapa.

3. Aplicação do questionário - versão preliminar: Logo após as mudanças de redação nas variáveis (itens), sugeridas pelos especialistas, para eliminar ambiguidades e incompreensão no enunciado, o instrumento foi aplicado na versão-preliminar à nossa amostra quantitativa da pesquisa. Essa etapa caracteriza uma nova validação do instrumento.

4. Reformulação de algumas questões do questionário: Os dados sociodemográficos que iniciavam o instrumento foram deslocados para o final do questionário com a finalidade de aproximar-se dos respondentes e criar um clima de confiança capaz de coletar dados particulares e pessoais. 
5. Aplicação do questionário - versão final: Depois de todas as etapas acima citadas, o instrumento chegou ao nível de aplicabilidade e foi remetido novamente à nossa população fonte. Os procedimentos de tabulação e análise dos dados foram os mesmos utilizados na teoria, como o teste Alpha de Cronbach na verificação da confiabilidade e consistência do instrumento. Dando continuidade aos procedimentos e à elaboração dos resultados desse estudo, foram utilizadas fontes da técnica de análises estatísticas com o auxílio do software SPSS 21 e o SPSS Amos, responsáveis pelas correlações dos dados quantitativos.

O questionário apresenta a sequência abaixo, no intuito de explorar todos os constructos propostos no método quantitativo.

Quadro 3 - Os Instrumentos Investigativos

Instrumento Investigativo: Questionário

\begin{tabular}{ll}
\hline & \multicolumn{1}{c}{ Instrumento Investigativo: Questionário } \\
\hline \multicolumn{1}{c}{ Partes do Questionário } & \multicolumn{1}{c}{ Constructos } \\
Performance da Tecnologia - & Expectativa de Performance/Desempenho. \\
TABLET & Intenção de Uso. \\
$\begin{array}{l}\text { Utilização do Tablet } \\
\text { Educacional }\end{array}$ & $\begin{array}{l}\text { Expectativa de Performance/Desempenho, Expectativa de Esforço, Influência Social e } \\
\text { Condições Facilitadoras. }\end{array}$ \\
$\begin{array}{l}\text { Fatores Determinantes do Uso } \\
\text { do Tablet Educacional }\end{array}$ & $\begin{array}{l}\text { Identificação do respondente e fatores moderadores do uso da tecnologia (gênero, } \\
\text { idade, experiência e voluntariedade de uso). }\end{array}$ \\
\hline Identificação do Respondente
\end{tabular}

Criado pela pesquisadora - Base UTAUT

O quadro 3 expõe a estrutura macro do questionário e a referência do constructo em evidência. Ele ainda está subdivido em seções para especificar cada constructo e facilitar a análise das respostas. Os itens da pesquisa foram avaliados seguindo uma escala tipo Likert de sete pontos, variando de concordo totalmente (7) para discordo totalmente (1). Com equivalência percentual de 1 a $0 \%$ até atingir 7 que corresponde a 100\%. A escala é simples e direta, com apenas um item para seleção, que aproxima da aprovação ou rejeição da assertiva apresentada. Ela é pertinente para analisar atitudes ou comportamentos, centro dessa pesquisa. 
A última seção, oitava, é destinada a questões abertas, dissertativas para atender particularidades dos participantes que não foram contempladas nas questões propostas anteriormente.

O orgagrama a seguir exprime como seu deu a construção do questionário e sua organização.

Figura 6 - Organograma do Questionário

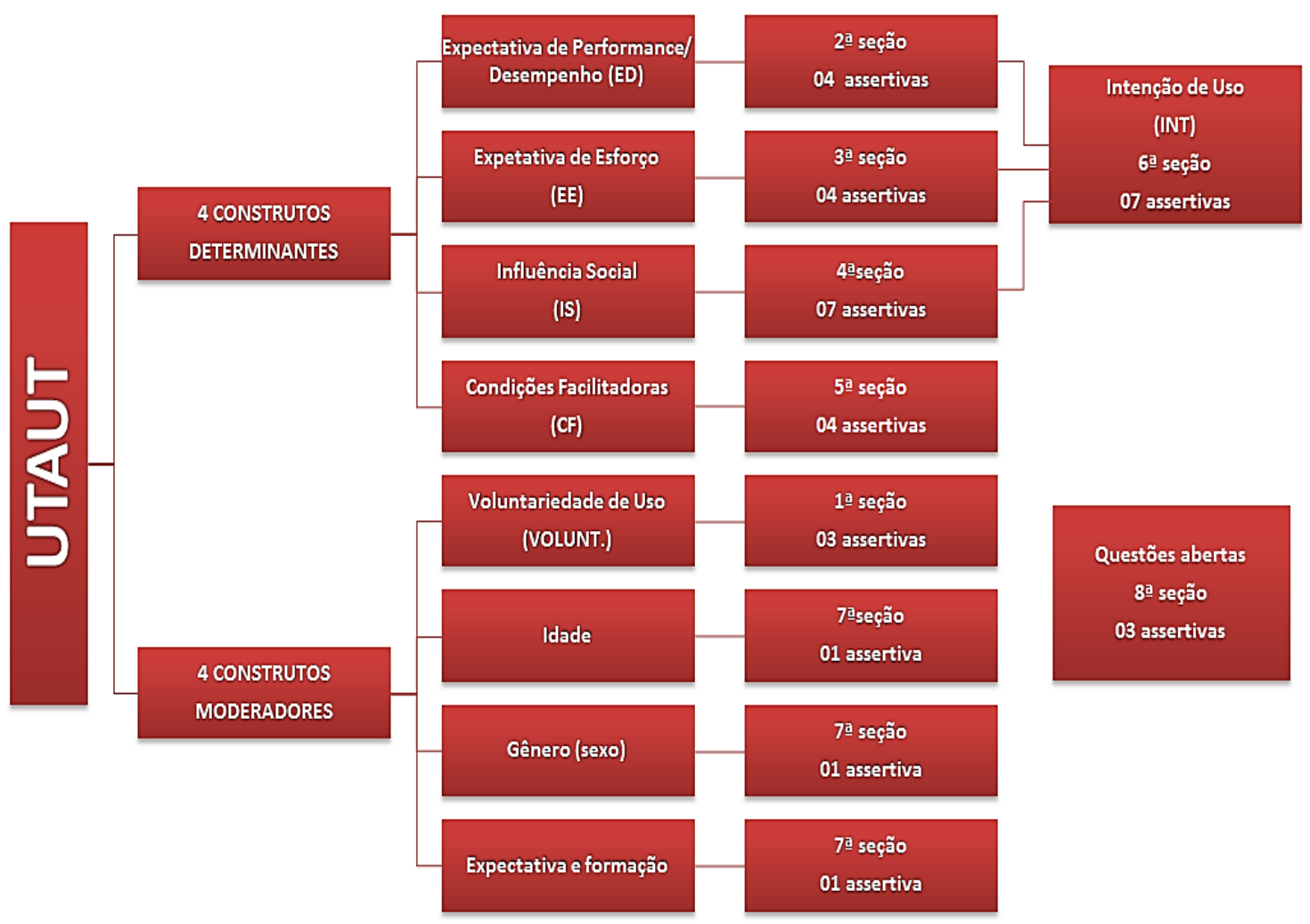

Fonte: Estrutura elaborada pela pesquisadora baseada na Teoria UTAUT

A estrutura acima apresenta os constructos e seus fatores seguidos das seções e do número de itens referentes em cada constructo. Ao lado do nome da cada constructo encontram-se as siglas utilizadas no programa SPSS. Há um número maior de assertivas nos constructos determinantes: Influência Social e Intenção de Uso, totalizando 07 itens cada. Esse quantitativo procurou atender a complexidade desses constructos e por serem mais abrangentes, enquanto os demais contemplam o assunto/temática com os números de itens expostos. 


\subsubsection{Entrevista Semiestruturada}

Para a coleta dos dados qualitativos, o instrumento entrevista semidirectiva ou semiestruturada serviu de base para essa etapa. Ela foi planejada previamente, como foco nos temas: comparação do Tablet Educacional a outros ofertados no mercado e possível influência a receptividade do produto; relevância do tablet ao contexto educacional; desempenho do professor no trabalho por meio do tablet; condições de uso antes e depois da formação; possibilidades de uso do tablet em sala de aula; pessoas facilitadoras neste processo de inserção da tecnologia e recursos ideais para seu uso.

Essa técnica de investigação visou complementar pontos obscuros ou mesmo não atendidos pelo questionário.

\subsection{Procedimentos para a Coleta de Dados}

Para realizar a fase da coleta de dados os procedimentos empregados foram: visitas nas escolas com o projeto; envio de correspondências via e-mail e por último, encontro agendado para realização da entrevista. A correspondência sobre o instrumento principal, via e-mail, ocorreu em circunstâncias diversas: no início da coleta de dados, depois, por volta de uns 10 dias após o primeiro envio e a última para encerrar essa coleta. Todo esse procedimento visava o acompanhamento e incentivo a pesquisa; Houve ainda, o convite para participar do segundo instrumento, a entrevista.

As entrevistas foram realizadas pela pesquisadora no ambiente de trabalho de cada professor participante, com data e horários pré-estabelecidos. Essa aproximação face a face facilita interações autênticas e permite observar e entender melhor algumas das respostas feitas pela movimentação das atividades da escola e das demais pessoas, além do comportamento dos entrevistados diante do seu local de trabalho, bem familiar. A duração dessa etapa foi, aproximadamente, de uma hora para cada entrevista, mas esse tempo era flexível para atender as peculiaridades de cada entrevistado.

Para o registro de dados dessa fase, seguiu-se o protocolo: 1. Apresentação dos objetivos do instrumento e da pesquisa; 2. Apresentação das perguntas e previsão da duração da entrevista; 3. Solicitação da gravação da entrevista. A importância dessa etapa recai na legitimidade nas respostas coletadas; 4. Preenchimento dos dados do entrevistado em um formulário; 5. Condução da entrevista; 6. Transcrição literal de cada pergunta feita; 7. Análise dos dados, a partir da análise de conteúdo proposta por Bardin (2009) e pelo software Nvivo. Todos esses processos estão explicitados a seguir. 


\subsection{Coleta de Dados}

Nesta seção, irei apresentar inicialmente a fase exploratória do questionário na versão preliminar, desde o convite, perpassando pela justificativa da sua aplicação a inferências de algumas assertivas. Em seguida, darei início a fase propriamente dita da nossa coleta de dados quantitativos com a versão final do questionário. Nesse momento também há a explanação de todo o processo de envio e o período dessa fase. Concernente aos dados qualitativos, explicarei a sua coleta por meio das entrevistas.

\subsubsection{Fase exploratória}

Primeiramente, houve uma visita às sete escolas para a apresentação da pesquisadora, explanação do objetivo desse estudo e o convite a todos os professores para a participação na pesquisa. Nesse primeiro contato, se pode conhecer a realidade local, o responsável da equipe gestora pelo acompanhamento do projeto e coletar os dados primários descritos na população fonte.

A segunda etapa consistiu na aplicação de um questionário on-line - versão preliminar. Esse tipo de instrumento, ou o pré-teste é importante para validar o conteúdo do instrumento de coleta de dados bem como, aperfeiçoar as questões, o formato e as escalas segundo Creswell (2010). Nessa situação, o envio dessa versão do questionário foi via correio eletrônico. No total de 299 e-mails enviados, 246 foram considerados enviados e válidos. No corpo do e-mail havia informações sobre a pesquisa e procedimentos de resposta ao formulário disponibilizado no link indicado no enunciado do e-mail.

A tabela 1, apresentada a seguir, resume o resultado do processo de envio e a dimensão da real população fonte envolvida. 
Tabela 1- E-mails enviados na versão preliminar do questionário

\begin{tabular}{|c|c|c|c|c|c|c|c|}
\hline & $\begin{array}{l}\text { CEM } \\
02\end{array}$ & $\begin{array}{l}\text { CEM } \\
03\end{array}$ & $\begin{array}{l}\text { CEM } \\
04\end{array}$ & $\begin{array}{l}\text { CEM } \\
09\end{array}$ & $\begin{array}{l}\text { CEM } \\
10\end{array}$ & $\begin{array}{l}\text { CEM } \\
12\end{array}$ & $\begin{array}{l}\text { CED } \\
14\end{array}$ \\
\hline Total de inscritos no projeto & 46 & 70 & 58 & 16 & 41 & 42 & 29 \\
\hline $\begin{array}{l}\text { E-mails com erro no endereço (E- } \\
\text { mails inválidos) }\end{array}$ & 09 & 07 & 07 & 03 & 05 & 03 & 04 \\
\hline E-mails não localizados & 00 & 08 & 08 & 01 & 01 & 00 & 00 \\
\hline Total de e-mails enviados válidos & 37 & 55 & 43 & 12 & 35 & 39 & 25 \\
\hline Percentual final de e-mails válidos & $80 \%$ & $78 \%$ & $74 \%$ & $75 \%$ & $85 \%$ & $92 \%$ & $86 \%$ \\
\hline
\end{tabular}

Fonte: Construída pela pesquisadora

Observemos na Tabela 1 (total de e-mails enviados válidos e no percentual desses dados) que, apesar de conseguir alcançar um número considerável do público, o retorno de questionários respondidos não alcançou $8 \%$ da população fonte. No entanto, algumas análises foram possíveis e significativas. Alguns resultados dessa etapa exploratória foram citados em forma de gráficos, de percentuais fornecidos pelos recursos do Google drive, nas quais foram a base inicial das análises com algumas inferências que irão subsidiar posteriores análises.

Essa etapa exploratória foi desenvolvida no final do ano de 2013 e início de 2014. A justificativa para a sua realização nesse período foi devido ao encerramento do curso de formação: Tablet: Formação de Professores de Ensino Médio voltado para o uso didático e pedagógico dos Tablets e das Tecnologias de Informação e Comunicação (TIC), no final do mês de novembro de 2013. O retorno dessa coleta foi de 19 respondentes. O gráfico 1 mostra o número de acessos para responder ao instrumento e a respectiva data. 
Gráfico 1 - Número de respostas diárias

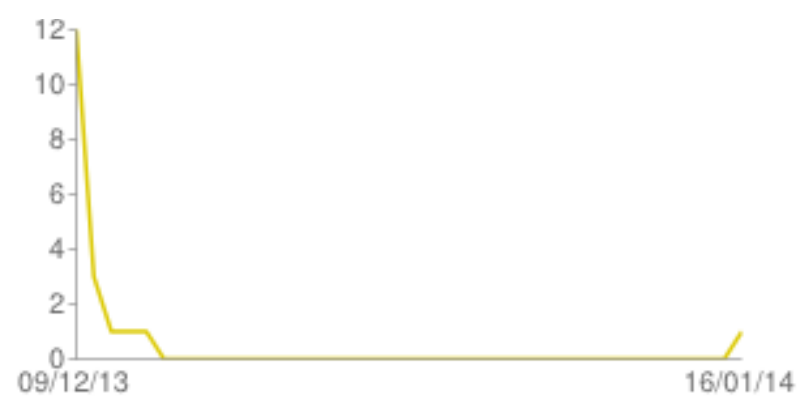

Fonte: Gráfico gerado pelo Google Drive - questionário versão preliminar

Podemos notar, no Gráfico1, uma oscilação maior de acessos logo nos primeiros dias, depois um período inerte e no final mais um pouco de movimentação. Esse fato pode inferir o retorno imediato da visita feita a escola, depois um esquecimento da pesquisa e uma retomada ao tema e a participação devido a finalização desse momento.

A primeira seção do questionário na versão preliminar inicia-se com dados sobre os fatores moderadores, destaque para:

O gênero

Gráfico 2 - Gênero

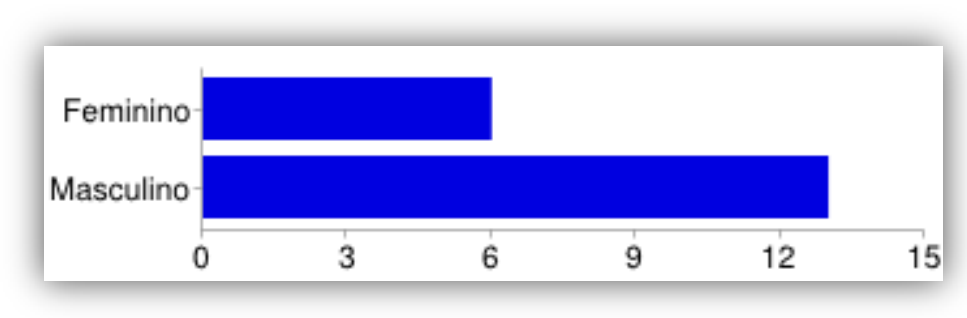

Fonte: Gráfico gerado pelo Google Drive - questionário versão preliminar

O gráfico 2 explicita que há uma diferença considerável de professores do gênero masculino em comparação ao gênero feminino nessa pesquisa, sendo $68 \%$ homens e $12 \%$ mulheres. 
A idade e a experiência em tempo de serviço:

Esses dois quesitos apresentam indícios de associação, pois o intervalo varia entre 28 anos a 53 anos de idade, enquanto o de serviço está entre 2 anos a 28 anos e 6 meses. A distância longitudinal entre o primeiro e o último é grande. Uma possível relação de distância também poderá ocorrer nos discursos, nas atitudes em relação às TDIC.

$>$ Cursos voltados às mídias:

O gráfico 3 ilustra os cursos voltados para as mídias, e índices de participação dos professores em cada um.

Gráfico 3 - Cursos voltados ${ }^{21}$ às mídias

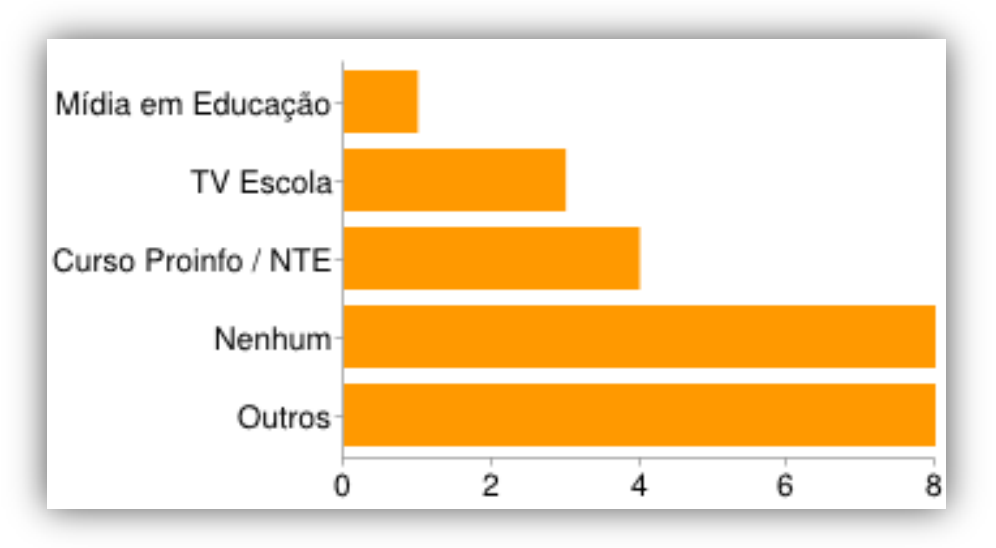

Fonte: Gráfico gerado pelo Google Drive - questionário versão preliminar

Pude notar que a partir das respostas, 34\% da nossa população fonte participaram dos cursos ofertados pelo Estado e 33\% de outros também atendendo a mesma temática, as mídias na educação. Por estes dados, percebe-se que os professores têm conhecimento das formações oferecidas pela SEDF/MEC e ainda que usufruem dessas ofertas.

\section{Familiaridade com o Tablet}

O gráfico a seguir ilustra a familiaridade com o tablet, consideremos seus dados:

\footnotetext{
${ }^{21} \mathrm{O}$ item TV Escola refere-se ao curso TV na escola e os desafios de hoje: Curso de Extensão para Professores do Ensino Fundamental e Médio da Rede Pública. UniRede e Seed/MEC/Coordenação de Leda Maria Rangearo Fiorentini e Vânia Lúcia Quintão Carneiro e não ao canal de televisão do Ministério da Educação. Então, lê-se: TV na Escola.
} 
Gráfico 4 - Familiaridade com o Tablet

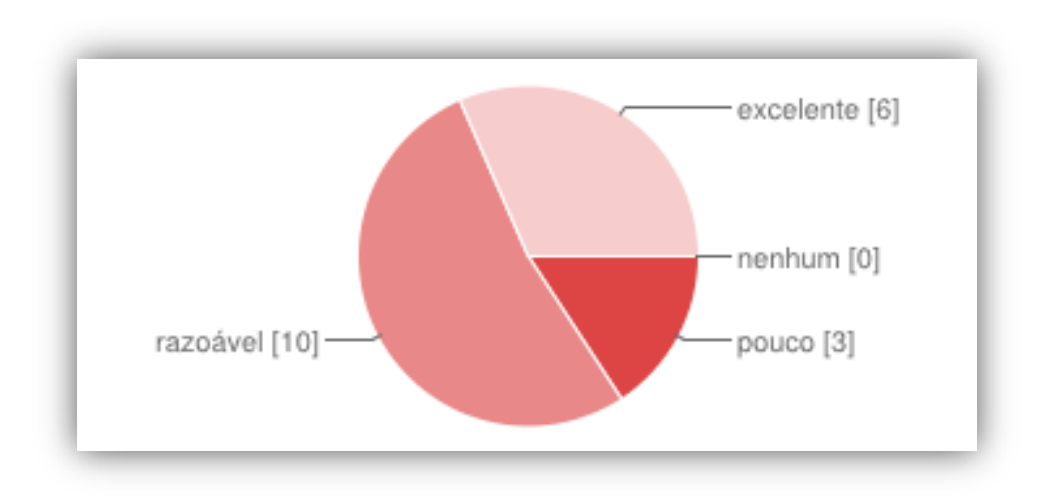

Fonte: Gráfico gerado pelo Google Drive - questionário versão preliminar

Apenas 6 professores admitem familiaridade com o tablet, os outros se julgaram com pouca (16\% dos participantes) ou razoável (53\%) familiaridade, o que corresponde um total de $69 \%$ dos participantes que conhecem o recurso tecnológico desta pesquisa, mas a maioria não se sente preparado ou com o domínio desta ferramenta a ponto de considerarem familiarizados com o tablet. Esse dado é bastante significativo, pois expressa que o professor precisa de formação para dominar as ferramentas e os recursos dessa tecnologia. Infere-se que os indivíduos possuem alguma experiência de uso com essa tecnologia. Mas até que ponto esse quesito modera ou não os demais constructos?

> Voluntariedade de Uso:

No questionário versão preliminar, três assertivas foram direcionadas a esse constructo: Voluntariedade de Uso, que faz parte dos Fatores Moderadores. Esse constructo visa avaliar o grau de vontade do usuário da tecnologia a fazer uso dela. No caso desta pesquisa, foi apontado o grau do professor em fazer uso do Tablet Educacional no contexto escolar. O retorno dessas três assertivas manifestou que:

$1^{a}$ assertiva: a maioria (84\%) tem consciência da sua autonomia em utilizar o recurso (Tablet) em seu trabalho.

$2^{\mathrm{a}}$ assertiva: $79 \%$ discordam de que os órgãos institucionais exigem a sua utilização. Essa postura reafirma a autonomia apresentada na assertiva anterior.

$3^{\text {a }}$ assertiva: E fechando a seção, $63 \%$ concordam com a relevância desse recurso no seu trabalho, sendo que $26 \%$ não opinaram. 
$>$ Condições Facilitadoras: o curso de formação

Análises adicionais foram realizadas para investigação do curso de formação como parte do constructo Condições Facilitadoras e com a intenção de aprofundar o entendimento desse tema foi perguntado aos pesquisados qual a sua motivação para participar do curso proposto pelo projeto. As condições objetivas mencionadas por Abbagnamo (2007) e os eventos circundantes citados por Jorge (2011), presentes na percepção, estão mais latentes nas respostas pela proximidade e envolvimento do professor no curso de formação. Há ainda outro fator, a liberdade do pesquisado de se expressar da maneira que quiser porque essa questão foi formulada como aberta. Esse tipo de questão atrai a abordagem qualitativa, a utilizada nesse momento, a partir da análise do conteúdo coletado. Empreguei a tipologia por semelhança que, segundo Guerra (2006), reagrupa os elementos por critérios de proximidade de conteúdo. Neste caso, os elementos estão destacados em negrito e sublinhados dos termos empregados pelos pesquisados. Ora as palavras são repetidas, ora são utilizados sinônimos ou termos similares à ideia principal. A partir dessa técnica, três categorias sobressaíram: Obrigação, curiosidade e aprimoramento. Segue o quadro com as opiniões acerca da motivação dos indivíduos ao curso.

Quadro 4- As categorias

Principais categorias

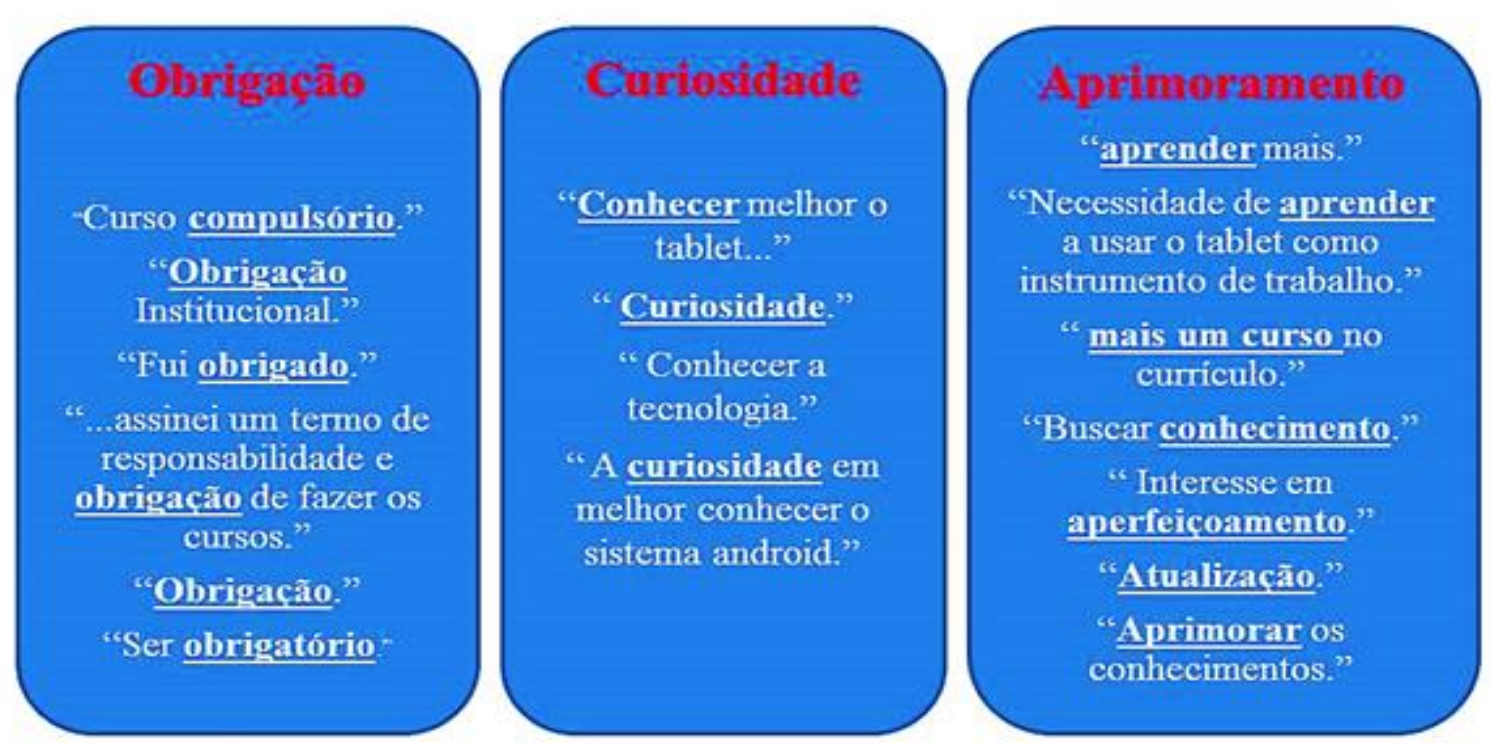

Fonte: Organograma criado pela pesquisadora 
A partir do quadro 4 pode-se notar que o professor possui a noção da obrigatoriedade do curso, e ainda vem imbuído da curiosidade pelo novo e pela busca do aprimoramento dos conhecimentos.

Ainda no conjunto de questões dissertativas, abertas, a última seção foi reservada aos pesquisados para exporem algo que o questionário não contemplou, ou ainda, uma sugestão ou crítica. Seguem alguns registros:

"Sugiro que a SEEDF ou as escolas, diretamente, adquiram os cabos, conectores e conversores necessários e adequados, caso contrário, na sala de aula, o tablet não servirá para nada." (Prof. 1)

"Gostei muito de puder manipular o tablet, participar do curso da EAPE, mas pena que não consegui finalizá-lo, pois o final de ano foi muito conturbado para mim,..." (Prof. 2)

"o tablet não disponhe de recurso para uso em sala de aula ou para gerenciamento administrativo." (Prof.3)

"Tenho receio que os alunos ficarão mais dispersos utilizando o tablet." (Prof.4)

"O uso do tablet será possível se for instalado na escola uma rede potente de Wi-fi e os alunos receberem os tablets." (Prof.5)

Livremente, os participantes discorreram sobre variadas pautas. Encerra-se a etapa exploratória, na qual os excertos acima podem destacar a preocupação (termos em negrito) de acessórios para o uso do tablet em sala de aula, as justificativas pela falta de conclusão no curso, os receios de uso aliados a perspectivas de ampliação para os alunos. São percepções que focalizam tanto aspectos objetivos como subjetivos, ressaltados por Abbagnamo (2007).

\subsubsection{Fase da coleta definitiva dos dados quantitativos}

Esta etapa da coleta de dados diz respeito ao questionário - versão final-. Seguindo os passos anteriores, também estive nas sete unidades de ensino para convidar os professores a participarem dessa nova etapa da pesquisa. Nesse momento presencial, houve a mobilização a essa fase com apresentação, novamente, tanto da pesquisadora como do objetivo do estudo. Infelizmente, não houve a reunião do quadro completo de professores envolvidos na pesquisa em nenhuma dessas visitas. 
O questionário final foi enviado por meio eletrônico, via e-mails, por atender a um número maior de participantes de diferentes localidades. Correspondências de acompanhamento foram enviadas no período do questionário final no intuito de estimular o envio de respostas adicionais.

O período de duração para essa fase foi aproximadamente 30 dias. As correspondências de acompanhamento foram enviadas no décimo e vigésimo dia, após o envio da pesquisa. Esses foram alguns mecanismos utilizados para obter o maior número de respostas dos questionários e de instigar o público-alvo à participação na pesquisa. A cada reenvio apenas havia alteração no título do e-mail: Primeiro convite à Pesquisa, Segundo convite à pesquisa e por fim, Terceiro convite à pesquisa. $\mathrm{O}$ conteúdo do e-mail encontra-se no apêndice A.

A integração do Gmail com o Google drive permite entre outras funcionalidades, a geração de resumo das respostas com gráficos e tabelas, conforme visualizados na versão preliminar do questionário. $\mathrm{O}$ intuito é analisar esses dados inicialmente com a oferta das funcionalidades do Google para avançar em análises mais complexas.

A coleta de dados desse instrumento ocorreu no período de 21 de julho a 22 de agosto de 2014, com 255 e-mails enviados e válidos. Foram obtidos 62 questionários respondidos, equivalente a $24 \%$ da população. Esse índice representa uma amostra pequena, mas que pode refletir a estrutura de interdependência dos dados de acordo com a teoria em questão. $\mathrm{O}$ aplicativo utilizado para as análises complexas quantitativas foi o IBM SPSS Statistics versão 21 e seus resultados estão mesclados nas demais análises qualitativas.

A tabela abaixo retrata a atualização de dados referentes aos e-mails, nosso canal de comunicação com a população fonte, e apresenta o resultado do processo do envio do questionário - versão final -. Os números em vermelho representam uma diminuição dos emails retornados devido a erros, pois obtive das equipes gestoras quadro atualizado dos emails dos professores envolvidos na pesquisa. 
Tabela 2 - E-mails enviados na versão final do questionário

\begin{tabular}{|c|c|c|c|c|c|c|c|}
\hline & $\begin{array}{l}\text { CEM } \\
02\end{array}$ & $\begin{array}{l}\text { CEM } \\
03\end{array}$ & $\begin{array}{l}\text { CEM } \\
04\end{array}$ & $\begin{array}{l}\text { CEM } \\
09\end{array}$ & $\begin{array}{l}\text { CEM } \\
10\end{array}$ & $\begin{array}{l}\text { CEM } \\
12\end{array}$ & $\begin{array}{l}\text { CED } \\
14\end{array}$ \\
\hline Total de inscritos no projeto & 46 & 70 & 58 & 16 & 41 & 42 & 29 \\
\hline $\begin{array}{l}\text { E-mails com erro no endereço (E- } \\
\text { mails inválidos) }\end{array}$ & 08 & 07 & 06 & 03 & 04 & 03 & 03 \\
\hline E-mails não localizados & 00 & 08 & 03 & 01 & 01 & 00 & 00 \\
\hline Total de e-mails enviados válidos & 38 & 55 & 49 & 12 & 36 & 39 & 26 \\
\hline Percentual final de e-mails válidos & $82 \%$ & $78 \%$ & $84 \%$ & $75 \%$ & $87 \%$ & $92 \%$ & $89 \%$ \\
\hline
\end{tabular}

Diante do insucesso nas respostas obtidas na primeira etapa, alguns procedimentos foram tomados no intuito de instigar a participação dos professores nesta pesquisa, como: a conversa com grupos de professores quanto à importância de sua participação no seu local de trabalho e o envio periódico dos e-mails com o questionário. O número obtido superou a primeira etapa tanto no envio de e-mails, quanto no retorno dos questionários respondidos, reflexo das medidas tomadas para instigar nosso público à participação.

\subsubsection{Fase da coleta dos dados qualitativos}

Esta é a última etapa tocante à coleta de dados e trata-se da entrevista semiestruturada, considerada uma forma de interação social, "em que uma das partes busca coletar dados e a outra se apresenta como fonte de informação" (GIL, 2010, p.109). A preocupação, neste momento, volta-se para os dados não quantificados, mais particulares, na tentativa de compreender a lógica que permeia a prática e a realidade escolar em relação ao Tablet Educacional. Essa coleta de dados ocorreu após análises do questionário versão final, pois o objetivo principal era a de complementar dados obscuros da fase primeira. As entrevistas seguiram um roteiro semidirigido com 14 perguntas. O período destinado a essa fase ocorreu do dia 06 de outubro à 14 de novembro de 2014. Todas foram gravadas no intuito de assegurar os dados repassados pelo entrevistador para análises posteriores. 


\subsection{Validação dos instrumentos}

A versão preliminar do questionário confirmou a adequação das assertivas propostas. No entanto, uma alteração foi necessária no enunciado da assertiva referente ao constructo Expectativa de Esforço: "Eu acho que o Tablet será fácil de usar em comparação com o computador, recurso que eu conheço". Essa assertiva abordava duas ideias que comprometeriam a compreensão da afirmativa: a comparação do recurso tablet ao recurso computador e a ideia de que o usuário já conhecia o último recurso. Após a alteração, a assertiva definitiva é: "Eu acho que o Tablet é fácil de usar em comparação ao computador." Não foi preciso eliminar, nem incluir novas assertivas; pois os resultados coletados nesta etapa atestam o instrumento. No entanto, para o questionário oficial, a referência verbal de algumas assertivas foi alterada, do futuro para o presente, porque neste momento, os respondentes já estavam com o recurso tecnológico - Tablet, e já concluíram a formação a cerca de seis meses. Houve ainda, um remanejamento da seção referente ao constructo Fatores Moderadores para a penúltima seção, estrategicamente, devido à familiarização do respondente ao instrumento proporcionando segurança em fornecer seus dados sociodemográficos.

Essa forma de coleta de dados ratificou a viabilidade do instrumento questionário online e validou a sua estrutura organizacional.

Nos estudos qualitativos, segundo Creswell e Miller (2000 apud CRESWELL, 2010), a validação é um dos pontos fortes e centra-se na determinação de resultados precisos do ponto de vista do pesquisador, do participante ou dos leitores. E para atender a autenticidade e fidedignidade dos dados, todas as entrevistas foram gravadas e a consulta poderia ser feita quantas vezes fossem necessárias. As transcrições foram feitas em quadros e conforme as falas dos entrevistados. As verificações seguiram o mesmo procedimento ao ouvir as falas e as transcrições, no intuito de certificar ocorrências de desvio. A descrição dos resultados procurou também atender ao quesito de autenticidade e fidedignidade, apresentando dados ricos em detalhes capazes de complementar e enriquecer nosso estudo, mais uma estratégia de validação.

\subsection{Estratégias e Instrumentos de Análise}

Os dados obtidos através do questionário e das entrevistas semiestruturadas foram coletados sequencialmente, durante o período destinado a coleta da pesquisa. A análise e resultados dos dados quantitativos são complementados com os dados qualitativos na 
tentativa de ampliar o entendimento das questões levantadas. Essa integração de análises e as discussões advindas retomam questões abordadas no início desse estudo. Pois, segundo Laville e Dionne (1999), o procedimento para ser completo deve retornar a intenção original a fim de averiguar se o problema ou questão primária foram atendidos. Averiguação que foi retomada e mencionada encontra-se nas considerações finais.

Para que todo esse processo culminasse nos resultados obtidos nesta dissertação algumas estratégias foram necessárias: protocolo de organização dos dados de cada instrumento e seleção dos softwares para auxiliar nas análises.

Quanto à organização dos dados quantitativos, os constructos mencionados e as orientações referentes ao Método UTAUT serviram de base para as análises. Foram seguidos os seguintes passos: 1) Amostragem dos que responderam e os que não responderam o questionário; 2) Análise do viés de respostas; 3) Análise descritiva dos dados para cada constructo do questionário; 4) Apresentação dos resultados em tabelas, figuras ou diagramas, proporcionadas pelo Google Drive; e 5) Interpretação dos resultados apresentados.

No que concerne à organização dos dados qualitativos, ela foi desenvolvida, conforme sugere Bardin (2009, p.121), em três momentos: 1) A pré-análise; 2) A exploração do material e suas categorias e 3) O tratamento dos resultados, a inferência e a interpretação.

Segundo Bardin (2009), a análise de conteúdo qualitativo está ligada à interpretação e trata- se de uma análise indutiva que não se opõe a quantificação. Além disso, a análise de conteúdo pode realizar-se a partir das significações que a mensagem fornece (BARDIN, 2009, p.165). Neste estudo, por se tratar de uma pesquisa que pretende compreender a receptividade dos professores para além das respostas imediatas e simplistas de afirmação ou negação, a análise de conteúdo parece adequada.

Como auxílio às análises dois softwares foram selecionados, cada qual para atender uma abordagem: o software SPSS - Statistical Package for the Social Sciences como suporte a parte quantitativa e o software Nvivo na parte qualitativa.

Muito utilizado em pesquisas de cunho quantitativas, o software SPSS - Statistical Package for the Social Sciences mostrou-se mais adequado devido a sua variedade de recursos que atendem às exigências da teoria UTAUT para verificação dos constructos. Utilizei dois produtos desse software, o SPSS 21 que auxiliou nas análises iniciais, como teste de Alfa Cronback para avaliar a consistência interna do grupo de variáveis, matriz de componentes. Essa versão permite visualizar os carregamentos da cada variável para os componentes (fatores) extraídos, KMO que indica a adequação do tamanho da amostra. O SPSS Amos mostra relacionamentos hipotéticos entre variáveis permitindo construir modelos 
de maneira mais precisa. De acordo com a teoria UTAUT, os constructos Expectativa de Performance/ Desempenho, Expectativa de Esforço e Influência Social são determinantes diretos da intenção comportamental para o uso da tecnologia em estudo, nosso caso, o Tablet Educacional. Já as Condições Facilitadoras estão diretamente relacionadas com o uso da tecnologia.

Quanto à estratégia de análise para os dados qualitativos, recorri também ao uso de recursos tecnológicos, apesar de menos usual neste contexto, seu uso está sendo utilizado com mais frequência, pois permitem agilidade ao processo. Nesta pesquisa optei por utilizar o software Nvivo, um software criado para a abordagem qualitativa, mas que pode ser usado também nos métodos mistos por apresentar dados quantitativos. Por meio dele a organização e análise dos conteúdos de entrevistas foram feitas com detalhes, além das ferramentas de busca, consulta e visualizações que possibilitam a execução de forma simples e direta.

A apresentação dos dados neste software segue um padrão. Há informações sobre dados de localização e ainda dados quantitativos da categoria (nó) criada. Exemplificados a seguir:

Local do dado: Exemplo: <Internas\\Quadro13_Questao13>.Ou seja, essa informação está no projeto criado dentro do programa(internas) e encontra-se no quadro 13 , questão 13.

Quantidade de referências tipificadas nessa categoria (nó): § 4 referências codificadas

Grau de cobertura geral: [11,43\% Cobertura]

* $\mathrm{N}^{\mathrm{o}}$ da referência do destaque e seu grau de cobertura individual na categoria (nó): Referência 1 - 3,12\% Cobertura

Logo após os fragmentos com as falas dos entrevistados aparecem em um quadro.

Essas estratégias de análise tiveram como finalidade compreender as informações coletadas e responder às questões da pesquisa apresentadas no objetivo geral e nos objetivos específicos.

Deve-se ressaltar ainda que tais análises integradas podem levar a insights advindos da combinação dos dois métodos. E que se pode ampliar a compreensão do problema em questão.

A partir dessa estrutura irei apresentar os resultados obtidos. 


\section{CAPÍTULO VI - RESULTADOS}

Esse capítulo versa sobre os resultados obtidos através dos instrumentos aplicados a fim de explorar os objetivos desta pesquisa. Primeiramente evidenciarei os dados quantitativos advindos do questionário - versão final -, através das análises fatoriais que averiguaram a aplicação da teoria UTAUT ao nosso estudo e suscitaram novas estruturas dos constructos propostos pela nossa população fonte. Apresentarei os resultados da confiabilidade desse questionário e por fim, os resultados de cada constructo especificamente. A segunda etapa consiste na apresentação dos dados qualitativos oriundos da entrevista semiestruturada. Neste momento, uma subseção delineia os achados obtidos pelo recurso tecnológico; Logo após, a atenção volta-se para as categorias pautadas por cada constructo pesquisado. Iniciemos.

\subsection{O questionário e os resultados quantitativos da teoria UTAUT}

Inicialmente, o questionário passou por uma inspeção inicial dos dados. Não foram encontrados casos ausentes, pois o questionário só poderia ser finalizado quando o participante preenchesse todos os campos, não sendo possível, portanto, deixar itens sem resposta. Os casos atípicos foram identificados através da análise dos gráficos de caixas, sendo identificados problemas em duas variáveis: a) Voluntariedade, com sete casos atípicos no item 2; e b) Intenção de uso, com dois casos atípicos no item 5. Em relação à primeira variável com problemas, a medida adotada foi a substituição pela média, enquanto que na segunda devido ao número pequeno que não corresponde a $5 \%$ dessa amostra, não foi dado nenhum tratamento aos mesmos considerando-os como missings.

Foram realizados procedimentos de Análise Fatorial Exploratória, que indicaram uma boa fatorabilidade da matriz de correlações $(\mathrm{KMO}=0,92)$. O programa permite várias formas de estruturas fatoriais, uma delas foi a análise do gráfico de sedimentação e o critério GuttmanKaiser, apontando para a possibilidade de extração de até sete fatores. No entanto, a melhor estrutura fatorial encontrada apontou para a presença de quatro fatores, que surgiram através do método dos eixos principais com rotação Varimax. A análise fatorial, em que as variáveis são testadas e agrupadas em um número exato de fatores nesse instrumento, desempenha o papel confirmatório da estrutura apresentada na teoria UTAUT, e ainda possui a finalidade de avaliar o grau em que os dados satisfazem ou não essa estrutura. E neste estudo, tal resultado corroborou a teoria UTAUT, que indica a presença de quatro constructos determinantes: Expectativa de 
Performance/ Desempenho, Expectativa de Esforço, Influência Social e Condições Facilitadoras. A distribuição dos itens e as cargas fatoriais de cada um são descritos na tabela abaixo e apresentam a junção em torno dos constructos da teoria:

Tabela 3 - Matriz de componente rotativa

\section{Matriz de componente rotativa ${ }^{\mathrm{a}}$}

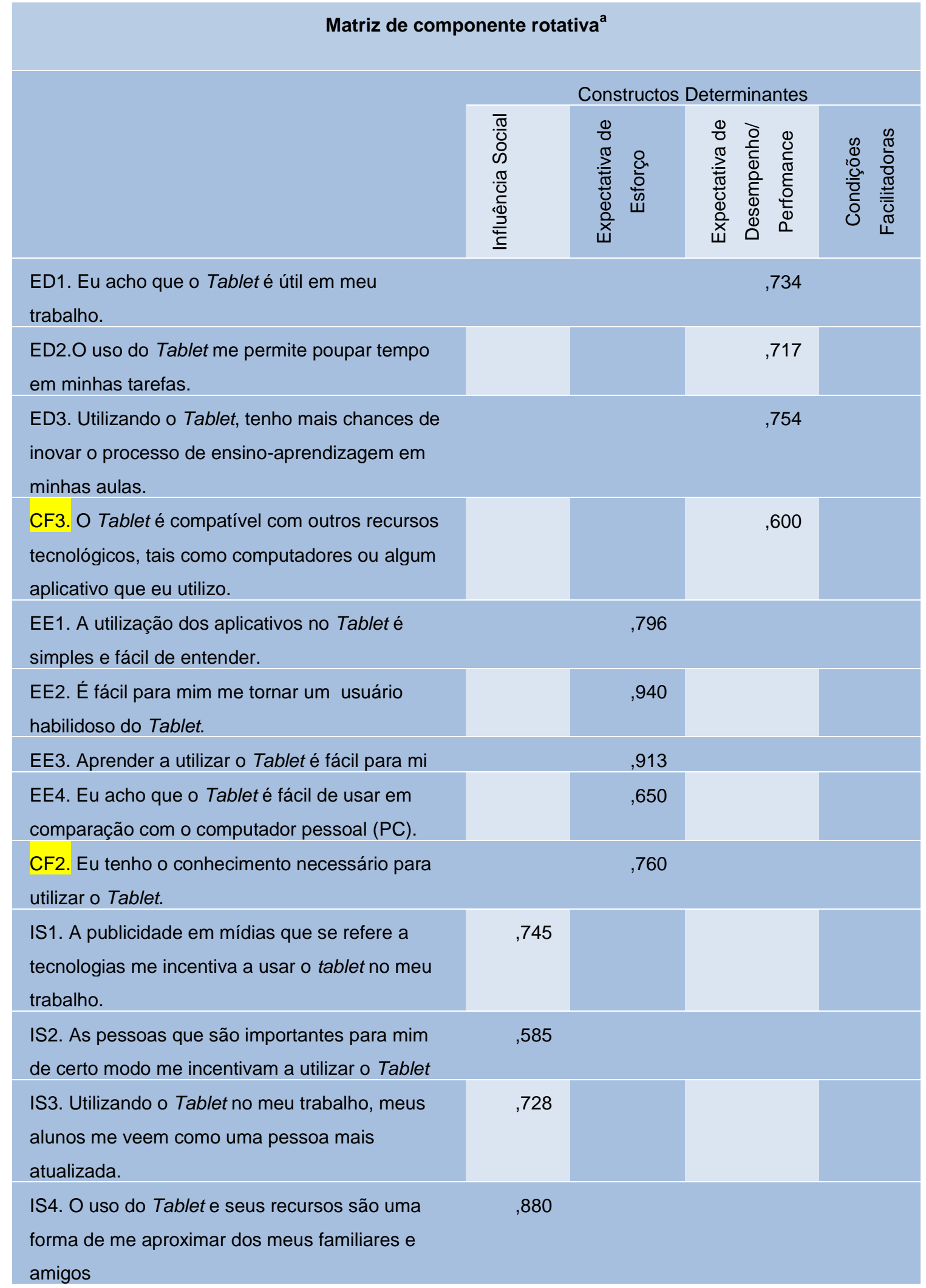




\begin{tabular}{l}
$\begin{array}{l}\text { IS5. O uso do Tablet e seus recursos são uma } \\
\text { forma de me aproximar dos meus alunos e dos }\end{array}$ \\
meus colegas de trabalho. \\
$\begin{array}{l}\text { ED4. O uso do Tablet melhora meu desempenho } \\
\text { no trabalho. }\end{array}$ \\
\hline CF1. Eu tenho os recursos necessários para \\
utilizar o Tablet como ferramenta pedagógica. \\
\hline CF4. Uma pessoa ou grupo está disponível para \\
ajudar quando eu tiver dificuldades com o Tablet. \\
\hline IS6. A direção e os demais professores da escola \\
têm me dado suporte para utilizar o Tablet. \\
\hline IS7. Em geral, os órgãos responsáveis (EAPE, \\
\hline NTE) tem incentivado a utilização do Tablet. \\
\hline
\end{tabular}

Fonte : Matriz gerada pela pesquisadora através do software SPSS 21

A matriz delineada no quadro acima apresenta como melhor solução os 4 fatores predominantes na teoria utilizada na pesquisa. Há o deslocamento de alguns itens que antes estavam em determinado constructo para outro, predispondo uma unificação em torno das questões dos mesmos. Fato observado e investigado de forma mais pontual nas entrevistas. No entanto, para entender melhor o que houve, segue o reagrupamento de cada fator encontrado e algumas inferências sobre o fato. A ordem seguida para tratar de cada constructo foi a mesma rodada na matriz.

O $1^{\circ}$ fator que é apresentado na matriz refere-se ao Constructo Expectativa de Desempenho. Ele concerne no grau que o indivíduo acredita que a tecnologia, Tablet Educacional, pode ajudá-lo em seu desempenho profissional. Acompanhe a estrutura que se evidenciou pelo grupo de professores participantes dessa etapa:

Na estrutura primária havia apenas as quatro variáveis, ED1 a ED4, no entanto, essa nova estrutura traz uma variável do constructo Condições Facilitadoras que se uniu a essa categoria. Deduz que a compatibilidade com outros recursos tecnológicos irá auxiliar no desempenho desse público.

No $2^{\circ}$ fator, destaca-se a Expectativa de Esforço, constructo que aborda o grau de facilidade percebida pelo usuário acerca do uso da tecnologia, que neste estudo refere-se à facilidade ao Tablet Educacional.

Neste fator, um dos itens do Constructo Condições Facilitadoras se incorporou a esse constructo. Esse agrupamento sugere que para esse público a condição de conhecimento do 
tablet não está diretamente relacionada com condições facilitadoras, pelo contrário, relacionase com o constructo de esforço.

O terceiro fator versa sobre o Constructo Influência Social. Ele baseia-se na percepção do indivíduo quanto à utilização de uma tecnologia pode influenciar a sua convivência com outros indivíduos, justificando o uso ou não dessa tecnologia. Nota-se na matriz que um dos itens do Constructo Expectativa de Desempenho se agrupou a esse constructo. Pode-se inferir que este grupo de professores associa o seu desempenho em utilizar o tablet como status social.

O quarto e último constructo determinante: Condições facilitadoras, diz respeito à infraestrutura técnica como auxiliar no uso das tecnologias.

De acordo com dados, o quarto fator foi composto por dois itens que compunham o Constructo Influência Social. Compreende-se que essas pessoas (direção, demais professores, EAPE, NTE) podem ser consideradas, para o professor, indivíduos que tenham infraestrutura técnica para ajudá-lo no uso dessa tecnologia.

\subsubsection{Confiabilidade do instrumento}

Para verificar a credibilidade dos dados obtidos do instrumento quantitativo utilizadoquestionário- foram calculadas as confiabilidades (Alfa de Cronbach) dos fatores. Na tabela 04, para cada constructo analisado, verifica-se que os valores são consistentes com os mencionados na literatura $(\alpha \geq 0,70)$ e adequados ao estudo desta pesquisa.

Tabela 4 - Confiabilidade das Escalas

\begin{tabular}{lcc}
\hline \multicolumn{1}{c}{ Escalas } & Alfa de Cronbach & N de itens \\
Influência Social (IS) & 0,905 & 6 \\
Expectativa de Esforço (EE) & 0,903 & 4 \\
Expectativa de Desempenho/ Performance (ED) & 0,881 & 5 \\
Condições Facilitadoras (CF) & 0,835 & 4 \\
\hline
\end{tabular}

Fonte : Tabela construída pela pesquisadora através do software SPSS 21

\subsubsection{Os constructos}

Os resultados a seguir referem-se a cada seção do questionário que examina um constructo da teoria UTAUT. Para auxiliar na compreensão e nos desdobramentos posteriores, segue o esquema dessa estrutura com as seções, os fatores evidenciados e as respectivas siglas utilizadas na análise quantitativa: 
Figura 7- Esquema da estrutura do questionário - Versão Final

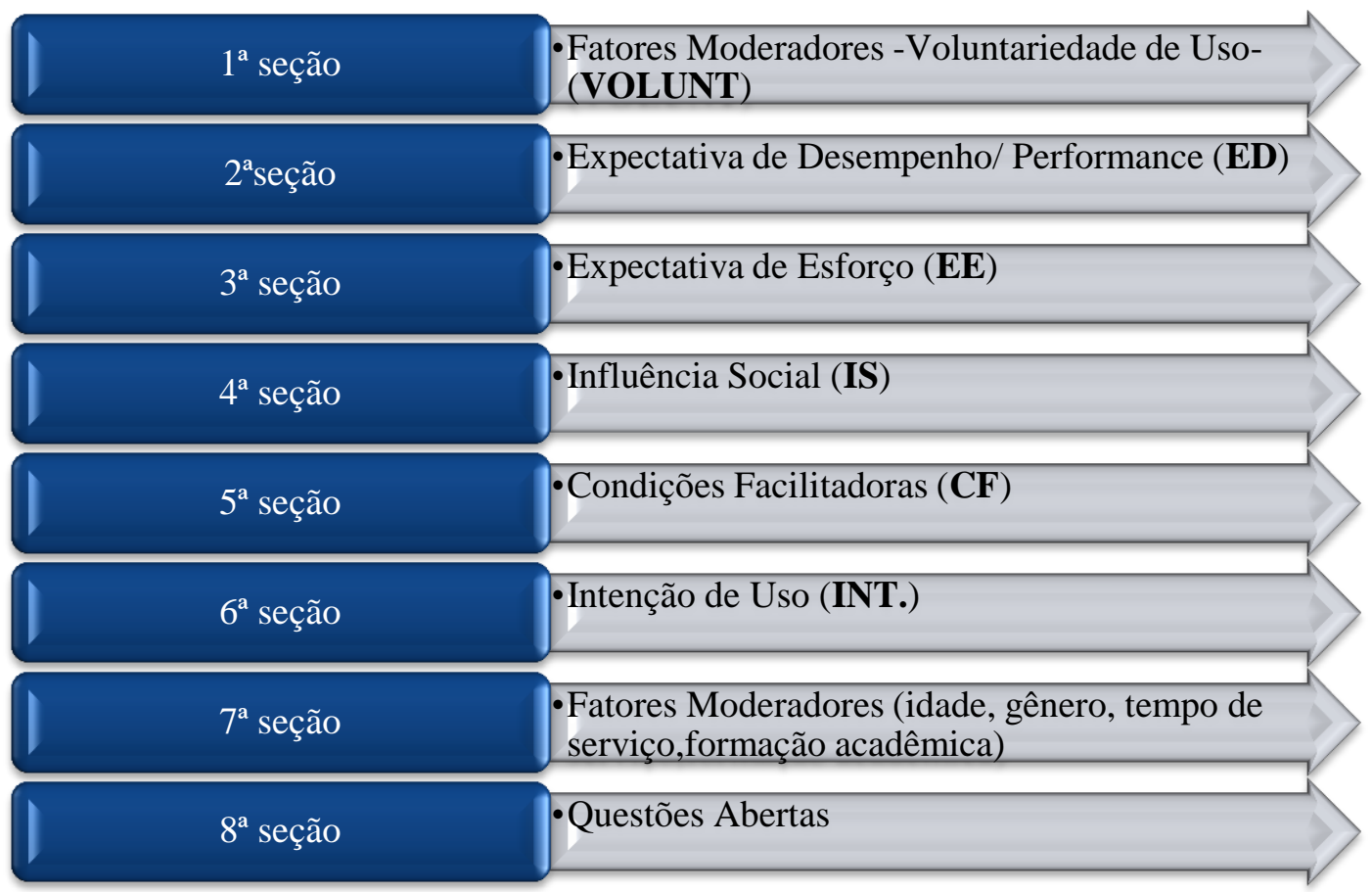

Fonte : criada pela pesquisadora com base na teoria UTAUT

Para verificar a relação entre os constructos foi estimado um modelo de equações estruturais, pelo método da verossimilhança. Nessa etapa, foi utilizado como base o modelo estabelecido por Venkatesh, Morris, Davis, \& Davis (2003). Mas de acordo com os resultados obtidos na pesquisa segue o modelo empírico decorrente:

Figura 8 - Modelo Empírico da Pesquisa

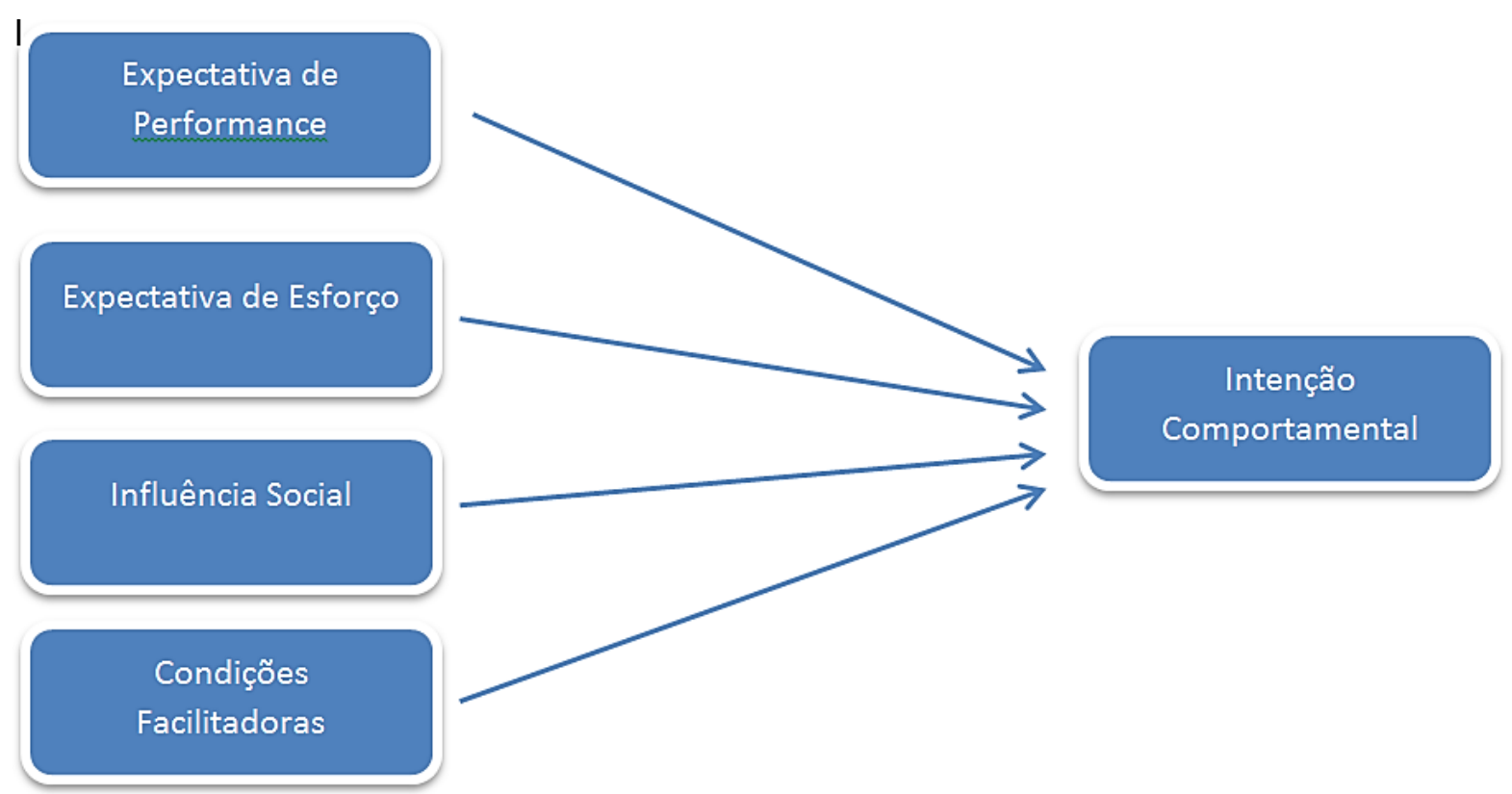

Fonte: Criado pela pesquisadora com base na teoria UTAUT e os resultados obtidos na pesquisa 
Convém ressaltar que o constructo Comportamento de Uso não foi testado no presente estudo, uma vez que os tablets foram disponibilizados aos professores no mesmo período desta pesquisa, ou seja, período de adaptação e formação para o uso dessa tecnologia, inviabilizando a mensuração desse comportamento. Por essa razão, o modelo de Venkatesh, et al (2003) serviu como base para a estimação de dois modelos, a saber:

1. Expectativa de Esforço (EE), Expectativa de Desempenho (ED) e Influência Social (IS) predizendo apenas a Intenção Comportamental (INT.); Esse modelo refere-se a uma parte da Teoria UTAUT.

2. Expectativa de Esforço (EE), Expectativa de Desempenho (ED), Influência Social (IS) e Condições Facilitadoras (CF) predizendo Intenção Comportamental (INT.)

Essas análises foram realizadas como testes e explorações dos modelos explicativos acima. No entanto, por razão de casos reduzidos (amostra insuficiente) não foram viáveis. Segue modelo abaixo para cada alternativa ensejada:

$\chi^{2}=205,821 ; \mathrm{gl}=87 ; \chi^{2} / \mathrm{gl}=2,366 ; \mathrm{SRMR}=0,2644 ; \mathrm{CFI}=0,82 ; \mathrm{RMSEA}(90 \%$ IC $)=0,150$ $(0,123-0,176)$ 
Figura 9 - Modelo 1 das equações estruturais da amostra global

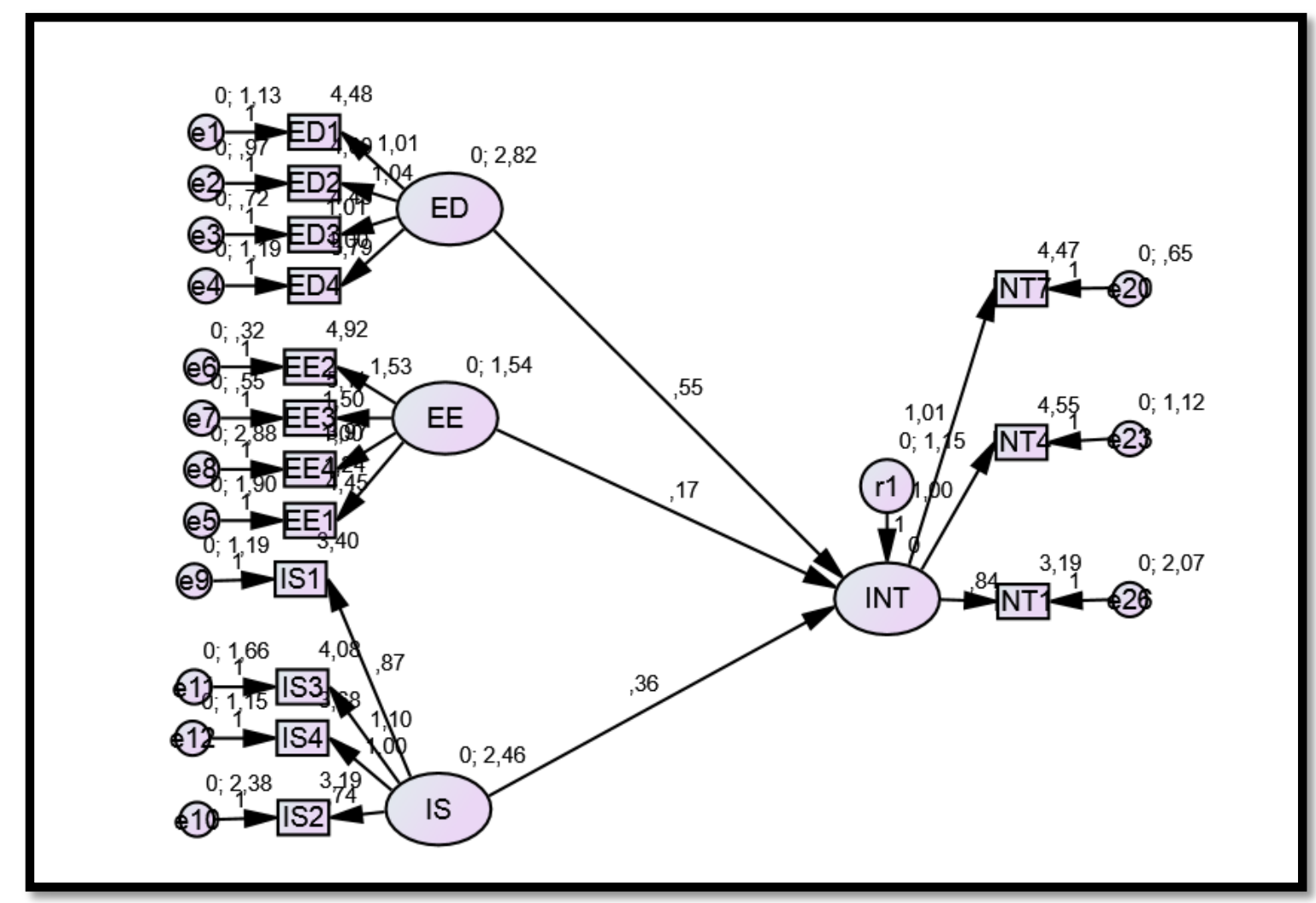

Fonte: Modelo gerado a partir dos dados coletados no questionário - versão final- pelo Software SPSS Amos

$\chi^{2}=437,207 ; \mathrm{gl}=185 ; \chi 2 / \mathrm{gl}=2,363 ; \mathrm{SRMR}=0,2901 ; \mathrm{CFI}=0,71 ; \mathrm{RMSEA}(90 \% \mathrm{IC})=$ $0,149(0,131-0,168)$ 
Figura 10- Modelo 2 das equações estruturais da amostra global

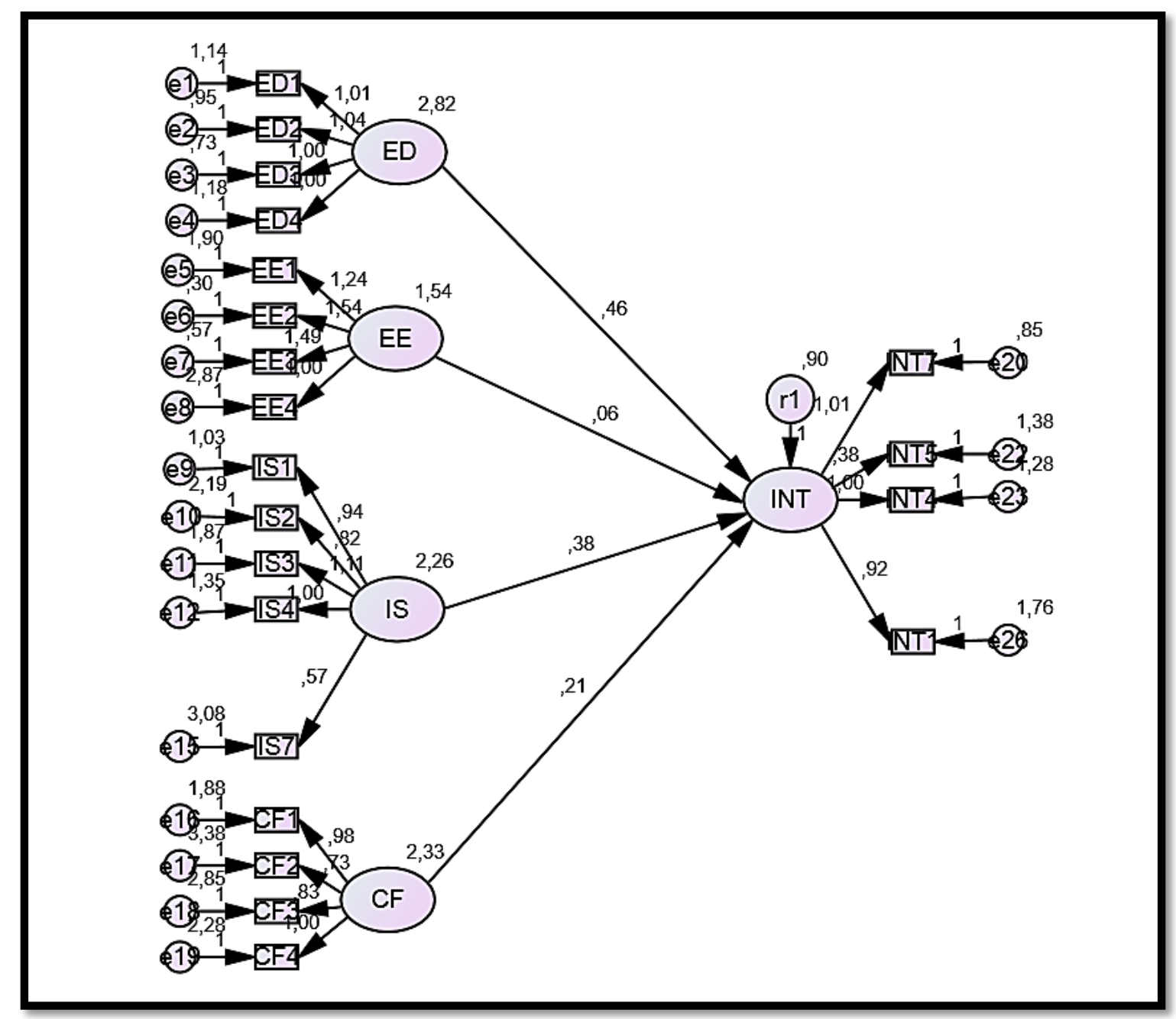

Fonte: Modelo gerado a partir dos dados coletados no questionário - versão final- pelo Software SPSS Amos

Esses resultados nos dois modelos podem ser decorrentes do tamanho reduzido da amostra, uma limitação ao nosso estudo. Contudo, essa análise estatística dos constructos e suas possíveis relações e influência, concluída, cumpre mais uma etapa de validação do estudo. Os dados compreendidos por meios dos nossos instrumentos são suficientes para outras análises. Vamos explorá-las.

\subsubsection{Constructo: Voluntariedade de Uso}

$\mathrm{Na}$ versão final do questionário, a primeira seção refere-se a um dos componentes do constructo Fatores Moderadores, a Voluntariedade de Uso. Segundo Venkatesh (2003), esse fator possui uma relação direta na Influência Social que aliado aos demais fatores moderadores (gênero, idade e experiência) projetam-se na intenção de uso da tecnologia. 
A partir das análises quantitativas constatou-se que os três itens referentes a esse constructo não se adequam a confiabilidade do instrumento, apresentando alfa de Cronbach $=$ ,- 094 .

Esse constructo, Voluntariedade de Uso, visa avaliar o quanto o pesquisado se sente obrigado a utilizar ou não o recurso, nesse caso, o tablet. E através das análises das frequências dos itens reveladas na tabela 5:

Tabela 5 - A decisão quanto a utilizar ou não o Tablet

\begin{tabular}{l|rrrrr}
\hline \multicolumn{6}{|c|}{ VOLUNT1. A decisão quanto a utilizar ou não o Tablet em meu trabalho cabe exclusivamente a mim } \\
\hline \multirow{2}{*}{ Válido } & Frequência & Porcentual & Porcentagem válida & Porcentagem acumulativa \\
\cline { 3 - 5 } & discordo inteiramente & 5 & 8,1 & 8,1 & 8,1 \\
discordo em parte & 7 & 11,3 & 11,3 & 19,4 \\
discordo & 1 & 1,6 & 1,6 & 21,0 \\
neutro & 7 & 11,3 & 11,3 & 32,3 \\
concordo & 3 & 4,8 & 4,8 & 37,1 \\
concordo em parte & 15 & 24,2 & 24,2 & 61,3 \\
\hline concordo inteiramente & 24 & 38,7 & 38,7 & 100,0 \\
\hline
\end{tabular}

Fonte : Tabela criada pela pesquisadora por meio do software SPSS 21

Com base nestes dados, que apresentam maior concentração em: concordo em parte e em concordo inteiramente; infere-se que os pesquisados demonstram ter autonomia em utilizar ou não o recurso tecnológico. Chamo a atenção também à tabela 6:

Tabela 6 - A SEDF/MEC exige que eu utilize o tablet

\begin{tabular}{|c|c|c|c|c|c|}
\hline \multirow{5}{*}{ Válido } & & Frequência & Porcentual & Porcentagem válida & Porcentagem acumulativa \\
\hline & 1 & 47 & 75,8 & 75,8 & 75,8 \\
\hline & 1 & 9 & 14,5 & 14,5 & 90,3 \\
\hline & 2 & 6 & 9,7 & 9,7 & 100,0 \\
\hline & Total & 62 & 100,0 & 100,0 & \\
\hline
\end{tabular}

Fonte : Tabela gerada pelo Google Drive com os dados coletados

Nesta tabela a frequência nesta variável apresenta apenas na escala os itens 1 e 2 , que referem respectivamente a discordo inteiramente, a discordo em grande parte, atestam que os professores pesquisados não se sentem pressionados pelos órgãos governamentais em utilizar o tablet. Novamente, reforça a autonomia do professor quanto ao uso ou não desta ferramenta tecnológica. 
Agora, comparando o comportamento apresentado anteriormente, na tabela 6, na concentração entre dois itens, a tabela 7 altera-se consideravelmente. Vejamos:

Tabela 7 - O uso do Tablet é relevante

\begin{tabular}{|cccccc}
\hline \multicolumn{5}{c}{ VOLUNT3. O uso do Tablet é relevante para o meu trabalho } \\
\hline & Frequência & Porcentual & Porcentagem válida & Porcentagem acumulativa \\
\hline \multirow{2}{*}{ Válido } & discordo inteiramente & 12 & 19,4 & 19,4 & 19,4 \\
\cline { 2 - 5 } & discordo em parte & 3 & 4,8 & 4,8 & 24,2 \\
\hline discordo & 3 & 4,8 & 4,8 & 29,0 \\
neutro & 22 & 35,5 & 35,5 & 64,5 \\
\hline concordo & 8 & 12,9 & 12,9 & 77,4 \\
\hline concordo em parte & 8 & 12,9 & 12,9 & 90,3 \\
\hline concordo inteiramente & 6 & 9,7 & 9,7 & 100,0 \\
\hline Total & 62 & 100,0 & 100,0 & \\
\hline
\end{tabular}

Ao analisar os dados acima, a neutralidade, por parte dos pesquisados, fica em evidência.

No universo de participantes, observe o gráfico 5:

Gráfico 5 - Gênero -Versão Final

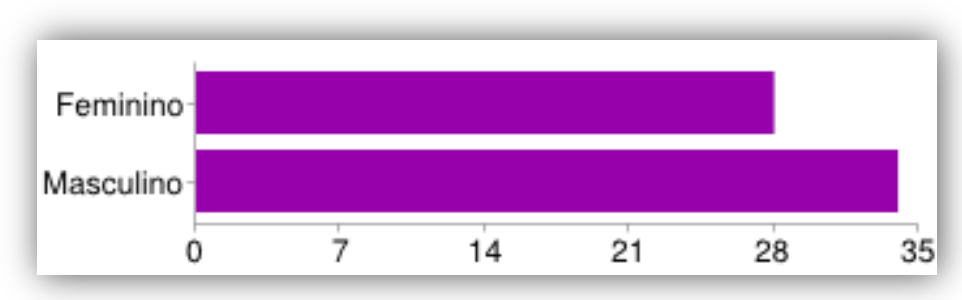

Fonte: Gráfico gerado pelo Google Drive com os dados coletados

Relativo ao fator idade, o intervalo varia de 28 anos a 55 anos de idade. Fato observado também na versão preliminar do questionário. Esse intervalo pode inferir que diferentes gerações estão envolvidas neste projeto e buscam um objetivo comum neste universo digital: a formação para o uso do Tablet Educacional. 


\subsubsection{Constructo: Expectativa de Desempenho/ Performance}

A segunda seção trata do constructo: Expectativa de Desempenho/ Performance, que pretende refletir o grau em que o indivíduo acredita que usando o recurso/ tablet, ele terá ganho no seu desempenho.

Esse constructo demonstrou um alto nível de confiabilidade com alfa de Cronbach 0 , 920. A tabela 8 , a seguir, mostra a média de cada item referente a esse constructo apresentado à população fonte:

Tabela 8 - Estatísticas do constructo: Expectativa de Desempenho

Estatísticas do constructo: Expectativa de Desempenho

\begin{tabular}{|c|c|c|c|}
\hline & Média & $\begin{array}{l}\text { Desvio } \\
\text { padrão }\end{array}$ & $\mathrm{N}$ \\
\hline ED1. Eu acho que o Tablet é útil em meu trabalho. & 4,48 & 2,022 & 62 \\
\hline ED2. O uso do Tablet me permite poupar tempo em minhas tarefas. & 4,00 & 2,024 & 62 \\
\hline $\begin{array}{l}\text { ED3. Utilizando o Tablet, tenho mais chances de inovar o processo de ensino- } \\
\text { aprendizagem em minhas aulas. }\end{array}$ & 4,45 & 1,905 & 62 \\
\hline ED4. O uso do Tablet melhora meu desempenho no trabalho. & 3,79 & 2,017 & 62 \\
\hline
\end{tabular}

Fonte: Tabela gerada pelo software SPSS 21 de acordo com os dados coletados

$\mathrm{Na}$ estrutura do questionário, quatro assertivas acerca dessa questão foram disponibilizadas, sendo que ED4 foi substituída por CF3 (ver Quadro 5, pág. 77) . A partir da tabela 8 pude inferir que a maioria dos pesquisados concordam que o tablet será útil no trabalho. E ainda, que o item referente ao desempenho (ED4) apresenta um percentual menor em relação à utilidade, ganho no tempo e na inovação no ensino-aprendizagem. O que ratifica o seu vínculo a outro constructo. A assertiva que soma a esse constructo (CF3) está relacionada com a compatibilidade do tablet a outras mídias. O professor da nossa pesquisa associa essa possibilidade com o ganho no seu desempenho, por isso essa adesão a esse constructo. No entanto, os percentuais obtidos: $47 \%$ discordam dessa afirmação, $15 \%$ não responderam e 38\% concordam, descrevem um desconhecimento por boa parte dos pesquisados relacionado à compatibilidade do tablet com outros recursos tecnológicos, característica própria do equipamento. Há também a possibilidade de integração com outros dispositivos tecnológicos existentes na escola, tais como o projetor Proinfo/MEC para o seu uso na sala de aula. Assunto previsto como conteúdo da formação, mas que pelos percentuais apresentados, não foi bem assimilado. 
Quanto à assertiva sobre a inovação no processo de ensino-aprendizagem com o uso do tablet (ED3), 53\% acreditam nesta possibilidade.

\subsubsection{Constructo: Expectativa de Esforço}

Esse constructo, Expectativa de Esforço, contempla a percepção que o professor tem sobre a facilidade de utilização do Tablet Educacional. Foram apresentadas quatro assertivas com o objetivo de verificar o grau desse constructo, porém de acordo com os pesquisados, mais uma assertiva se inclui ao grupo (ver Quadro 6, pag. 77) . E nas três primeiras assertivas houve uma regularidade na aceitação das ideias apresentadas (utilizar os aplicativos do tablet, tornar-se usuário habilidoso e utilizá-lo), perfazendo em torno de $65 \%$ o somatório dos percentuais. Enquanto que na assertiva que aborda a facilidade de uso do tablet em comparação com o computador pessoal, o percentual de concordância foi de $47 \%$ e de discordância 39\%. Percebe-se que os pesquisados não associam a facilidade do tablet ao do computador, talvez por ser uma tecnologia nova e de pouco conhecimento comparado ao computador, recurso mais usual e presente nas escolas há mais tempo. A última assertiva integrante a esse constructo trata dos conhecimentos para o uso do tablet, 55\% confirmam têlos para seu uso. Índice que confirma a visão da maioria dos pesquisados ao associar os conhecimentos prévios com o esforço para manusear e utilizar o tablet.

O gráfico 6 apresenta o grau de familiaridade com o recurso tecnológico Tablet Educacional da população fonte quantitativa. O título do gráfico traz a assertiva feita aos pesquisados. Ao comparar esse gráfico com o próximo, gráfico 7, que traz os dados da formação voltadas às mídias dos nossos professores, em que 52\% possuem formação em alguns dos programas oficiais do governo, em contradição aos $48 \%$ restantes aos índices do constructo em questão, Expectativa de Esforço, é possível supor que o grau de esforço está intimamente ligado ao conhecimento e familiaridade com essa tecnologia e consequentemente, influencia a intenção de uso e seu comportamento frente a esse uso. 
Gráfico 6 - Qual o seu grau de familiaridade com o recurso tecnológico- Tablet e seus aplicativos

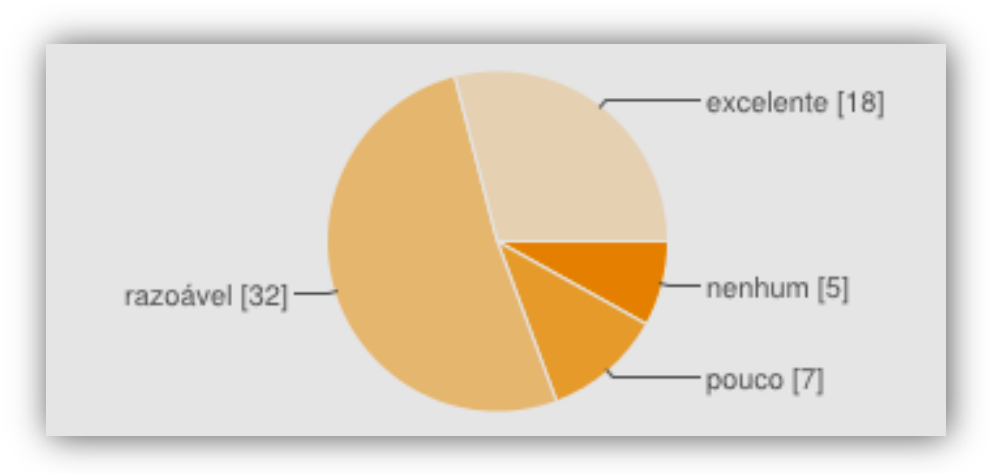

Fonte: Gráfico gerado pelo Google Drive a partir dos dados coletados

Gráfico 7 - Participou de outros cursos voltados às mídias?

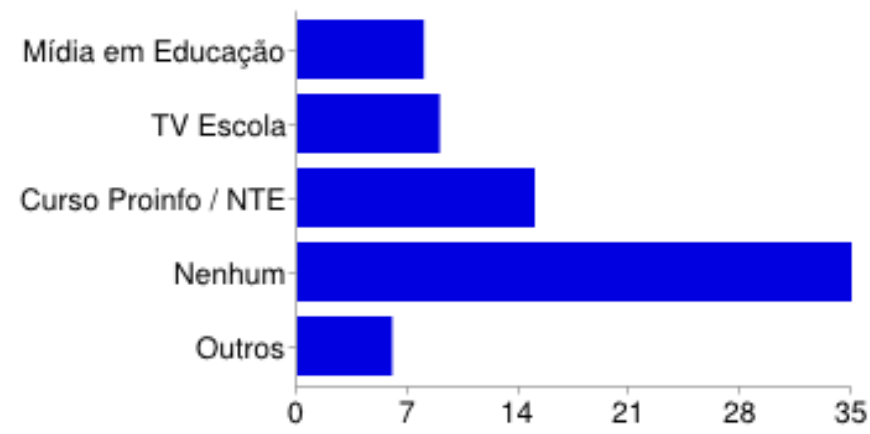

Fonte: Gráfico gerado pelo Google Drive a partir dos dados coletados

No entanto, a população fonte não considera o tablet mais fácil quanto se associa ao computador, um recurso mais conhecido e utilizado no âmbito escolar como se pode ver no gráfico 8. Corroborando com a nossa dedução a esse constructo: familiaridade e conhecimento influenciam no grau de esforço á essa tecnologia e consequentemente a sua intenção de uso. 
Gráfico 8 - Eu acho que o Tablet é fácil de usar em comparação com o computador pessoal (PC)

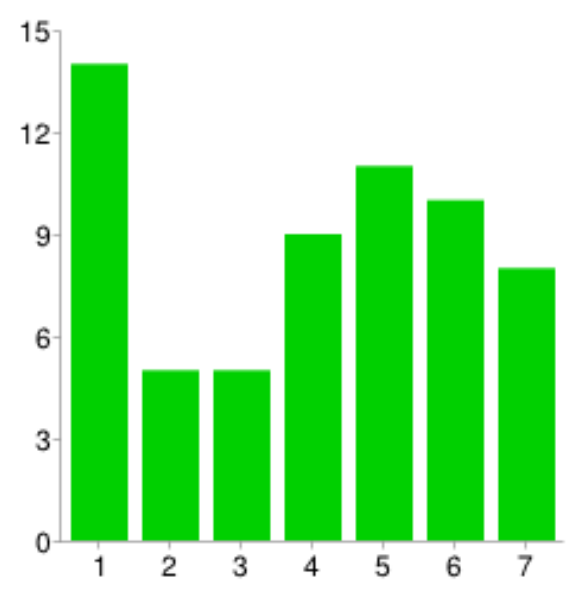

Fonte: Gráfico gerado pelo Google Drive a partir dos dados coletados

\subsubsection{Constructo: Influência Social}

A quarta seção focou no grau de percepção que o indivíduo possui em relação ao uso do recurso tecnológico e sua influência no convívio social, referência ao constructo: Influência Social. Com o propósito de atingir o maior número de influências sociais, essa seção apresentava sete assertivas (ver seção no apêndice B) que estavam direcionadas ao campo profissional, alunos, colegas de trabalho, direção e órgãos institucionais envolvidos no projeto Educação Digital, assim como no campo familiar e no campo publicitário. No entanto, a estruturação final tem seis itens, sendo que dois itens deslocaram-se para o constructo Condições Facilitadoras e um item da Expectativa de Desempenho se integrou a esse constructo. Vamos às análises:

No campo publicitário, as respostas apresentadas demonstram que o professor não se deixa influenciar pela mídia. Pode-se deduzir autonomia e consciência do seu papel frente a novas e possíveis mudanças. Demonstra um posicionamento crítico a divulgação e marketing comerciais. Observe o gráfico: 
Gráfico 9 - A publicidade em geral me incentiva a usar o tablet no meu trabalho

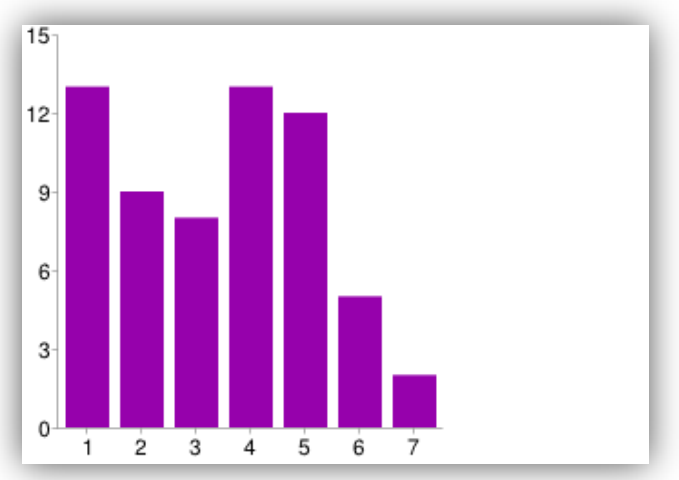

Fonte: Gráfico gerado pelo Google Drive a partir dos dados coletados

Quando analisei as pessoas que são importantes para os pesquisados, $49 \%$ não as veem como pessoas incentivadoras para o uso, $23 \%$ não opinaram e $28 \%$ consideram essas pessoas como incentivadoras, ou seja, a avaliação geral é de que a nossa população fonte não se deixa influenciar por algumas pessoas. No entanto, quando o campo é o profissional há uma dicotomia evidente nos resultados se for tratar do aluno e sua visão: 50\% concordam que com o uso da tecnologia o aluno o vê mais atualizado, enquanto que $40 \%$ discordam. Observem o gráfico 10:

Gráfico 10 - Utilizando o Tablet no meu trabalho, meus alunos me virão como uma pessoa mais atualizada

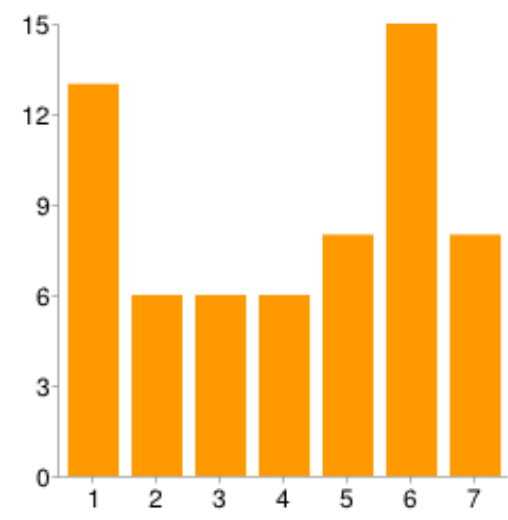


O nosso pesquisado se vê confuso ao tratar do uso do tablet como forma de aproximação, seja com familiares, alunos, os colegas de trabalho. Ele não está convencido que essa tecnologia seja capaz disso, representação pelos índices de duas assertivas (IS4 e IS5), para a primeira que relaciona com os familiares, foram $35 \%$ que discordaram desse atributo, $31 \%$ não opinaram e $34 \%$ concordaram. E na segunda assertiva que abarca alunos e colegas de trabalho poucas mudanças a primeira, variação para os que não opinaram $26 \%$ e $38 \%$ para os que concordaram com a afirmativa.

Quanto à última assertiva desse constructo, ED4, nossa população fonte ao categorizála neste constructo, nos narra: a atuação com o tablet no trabalho influencia a visão desse professor perante os outros indivíduos que convivem no mesmo espaço escolar. Mas essa mesma população não tem certeza dessa influência retratada pela pulverização das respostas ao item: $43 \%$ discordam, $10 \%$ não se expressaram (neutralidade) e $47 \%$ concordam.

\subsubsection{Constructo: Condições Facilitadoras}

Na quinta seção, quatro assertivas foram utilizadas para mensurar o constructo: Condições Facilitadoras, desde recursos e conhecimentos necessários para o uso do tablet a compatibilidade do mesmo com outros aplicativos. Além de ater-se a captar a percepção em relação à ajuda de pessoa ou grupo caso haja dificuldades no uso do equipamento. Esse constructo está diretamente voltado para o comportamento de uso da ferramenta tecnológica. Caso o usuário não perceba essas facilidades poderá desistir do seu uso. No entanto, somente duas assertivas permaneceram neste grupo e outras duas referentes à Influência Social, segundo a nossa população fonte, se adéquam neste constructo. $\mathrm{O}$ panorama atual dos resultados reflete o momento em que os professores vivenciam o projeto, seis meses após seu início, e o retorno foi totalmente contrário à fase da versão preliminar, o começo do mesmo, no qual, os pesquisados demonstraram confiança tanto nas pessoas, como nas demais condições.

Quanto aos demais profissionais desse ambiente, direção, professores e órgãos institucionais, 64\% não identificam esses pares, gestores, os órgãos, no Constructo Influência Social, mas como facilitadores para o uso do recurso tecnológico- tablet- na escola. Esse percentual difere significativamente do questionário - versão preliminar, em que $42 \%$ acenam ter confiança nessas pessoas no suporte para o uso do tablet. Essa mudança de postura pode ser reflexo de momentos distintos, pois durante o envio da versão preliminar os participantes estavam na formação, envolvidos com o projeto e após seis meses, o panorama mudou. Não 
há nenhuma assistência, informações, encontros, discussões ou indícios de continuidade do mesmo pelos órgãos responsáveis. E valida o seu deslocamento para esse constructo.

\subsubsection{Constructo: Intenção de Uso}

A seção 6 do nosso instrumento centra-se na Intenção de Uso, a abordagem visa avaliar o grau que o professor planeja utilizar o recurso. Esse constructo destaca-se dos demais porque seus dados refletem a intenção dos nossos pesquisados em utilizar o Tablet Educacional e consequentemente apresentam o nível de aceitação dessa tecnologia e sua receptividade no ambiente escolar, nosso objetivo maior nesta pesquisa. Inicialmente, na geração de dados, o Alfa de Cronbach desse constructo foi de 0,917 para os 6 itens, excelente índice de confiabilidade o que nos permite analisar com maior precisão. Na tabela 9, abaixo, apresenta as médias e os desvios padrão de cada assertiva. Vejamos:

Tabela 9 - Estatísticas do Fator: Intenção de uso

\begin{tabular}{|c|c|c|c|}
\hline \multicolumn{4}{|c|}{ Estatísticas do Fator: Intenção de uso } \\
\hline & Média & Desvio padrão & $\mathrm{N}$ \\
\hline INT1. Eu planejo utilizar o Tablet nos próximos meses. & 3,07 & 2,007 & 60 \\
\hline $\begin{array}{l}\text { INT 3. Tenho a intenção de tirar o máximo proveito do } \\
\text { tablet em meu trabalho. }\end{array}$ & 4,12 & 2,009 & 60 \\
\hline $\begin{array}{l}\text { INT4. Eu pretendo descobrir novas formas de usar o } \\
\text { Tablet em meu trabalho. }\end{array}$ & 4,47 & 2,071 & 60 \\
\hline $\begin{array}{l}\text { INT5. O Tablet é sempre minha primeira escolha dentre } \\
\text { as tecnologias disponíveis na minha escola e no meu } \\
\text { trabalho. }\end{array}$ & 1,87 & 1,384 & 60 \\
\hline $\begin{array}{l}\text { INT6. Eu pretendo integrar o Tablet à minha prática } \\
\text { pedagógica. }\end{array}$ & 4,03 & 1,974 & 60 \\
\hline $\begin{array}{l}\text { INT7. Quando necessário, ajustarei a forma do Tablet à } \\
\text { minha forma de ensino-aprendizagem. }\end{array}$ & 4,38 & 1,967 & 60 \\
\hline
\end{tabular}

Um dado explícito na tabela 9 refere-se à assertiva 5 que sanciona a rejeição da mesma, ou seja, do Tablet Educacional como primeira opção de uso. Confirmação refletida também quando retomo os percentuais dessa afirmativa: $80 \%$ discordaram, $8 \%$ imparciais e somente $12 \%$ sinalizaram essa intenção de uso. Outro dado evidente, diz respeito ao desvio padrão desse construto, o que demostra o quão distante as assertivas estão distantes uma das outras, pulverização nos dados. 
Atentemos para as outras seis assertivas elencadas nesta seção. Porém, gostaria de frisar que na teoria UTAUT esse constructo Intenção de Uso tem influência direta de 3 outros constructos: Expectativa de Desempenho/ Performance, Expectativa de Esforço e Influência Social. Então, os resultados obtidos nos remeterão a um ou outro desses constructos determinantes. Vamos a eles:

$32 \%$ pretendem utilizar o tablet nos próximos meses; Percentual menor do que na versão preliminar, que foi $79 \%$. Esses percentuais reafirmam, assim como demonstrado no constructo Condições Facilitadoras, que essa postura antagônica é reforçada pelos acontecimentos durante esse período de coletas, 6 meses, tais como: término do curso e nenhuma ação governamental para continuidade de formação para essa tecnologia, falta de incentivo ao uso do tablet, descobertas de incompatibilidade de aplicativos ou recursos já utilizados pelo professor e que não suportam nesta tecnologia, exemplo: o diário eletrônico.

$82 \%$ assinalaram a continuidade de uso de outros recursos tecnológicos conhecidos, em detrimento ao Tablet Educacional, ou seja, não haverá uma substituição, nem mesmo uma integração das mídias existentes no contexto escolar;

49\% possuem a intenção de tirar o máximo de proveito do recurso no seu trabalho;

$>$ O percentual aumenta para $60 \%$ quando o cerne é a descoberta de novas formas de uso no trabalho. Essa confiança demonstra autonomia, criatividade, habilidades necessárias neste século. Segundo a Unesco (2009) as habilidades do século XXI são capazes de solucionar problemas de comunicação, colaboração, além de envolver experimentação, pensamento crítico e expressão criativa.

Quanto a ser a primeira opção de uso, o tablet não vem com essa prerrogativa, $80 \%$ não o colocam neste patamar. Talvez o fato se deva por ser um recurso novo e requerer outras habilidades, ou conhecimentos para desenvolver atividades que envolvam multimídia, comunicação on line, colaboração e aprendizagem baseada em projetos.

$>35 \%$ sinalizaram a disposição de integrar o tablet a sua prática pedagógica. 
A última assertiva: Quando necessário, ajustarei a forma do Tablet à minha forma de ensino-aprendizagem, teve $84 \%$ de aceitação pelos pesquisados, conforme gráfico 11 . No entanto, fica a dúvida: Qual seria essa forma?

Gráfico 11 - Ajuste do Tablet Educacional à forma de ensino-aprendizagem

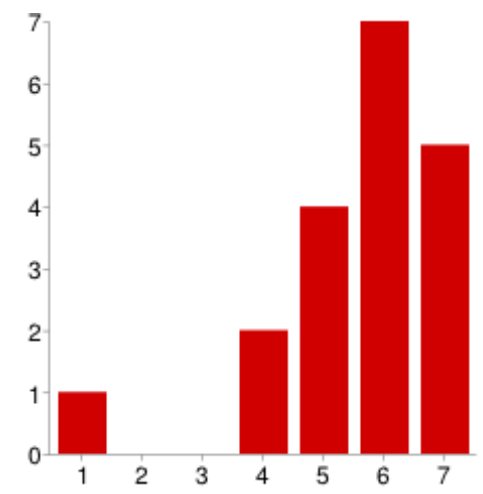

Fonte: Gráfico gerado pelo Google Drive com os dados coletados

Esses foram os resultados quantitativos evidenciados pela pesquisadora no decorrer da pesquisa. Passarei agora a parte qualitativa.

\subsection{A entrevista e os resultados qualitativos da teoria UTAUT}

Essa seção visa analisar a partir das comunicações de sete professores, cada um representando uma escola atendida no projeto, às expectativas dos mesmos em relação ao Tablet Educacional, seus recursos, a formação e outros temas que possam contribuir com os dados desta pesquisa. A entrevista vem com o intuito de se aproximar mais da realidade dos participantes envolvidos na pesquisa, pois segundo Bardin (2009):

Esta atitude de "vigilância crítica" exige o desvio metodológico e o emprego de "técnicas de ruptura" e afigura-se tanto mais útil para o especialista das ciências humanas quanto mais ele tenha sempre uma impressão de familiaridade face ao seu objeto de análise. (Bardin, 2009, p.30)

Nosso objetivo é seguir a estrutura da teoria UTAUT utilizada anteriormente, mas o foco centralizou-se nas questões que ficaram obscuras e imprecisas, durante a etapa survey, para a interpretação dos dados. Vamos, então, aos resultados. 


\subsubsection{Apresentação da estrutura do instrumento pelo Nvivo}

Posteriormente aos trabalhos de campo, o tratamento dos dados seguiu as seguintes etapas: a transcrição das entrevistas agrupadas de acordo com cada questão feita aos participantes; criação do projeto dentro do software NVivo, transferência das "Fontes" oriundas das entrevistas, criação dos "Nós", a codificação manual e a análise dos dados e a elaboração dos relatórios para apresentação dos resultados.

O uso do software Nvivo10 possibilita fazer novas combinações e interações com os dados coletados, emergindo novas perspectivas e inferências que somam às iniciais do pesquisador, por isso seu uso nesta pesquisa.

Mediante os dados coletados foram obtidas 14 pastas associadas às 14 perguntas feitas durante as entrevistas, nossas fontes de pesquisa. Na análise inicial foi realizada uma "leitura flutuante" para averiguação da frequência de presença ou mesmo de ausência de itens que permitam inferir sobre algum constructo em destaque, com objetividade foi utilizado o método das categorias. No caso do software, as categorias são os nós criados, conforme se pode averiguar na figura 11: 
Figura 11 - Visualização das Categorias (Nós) da pesquisa no Nvivo

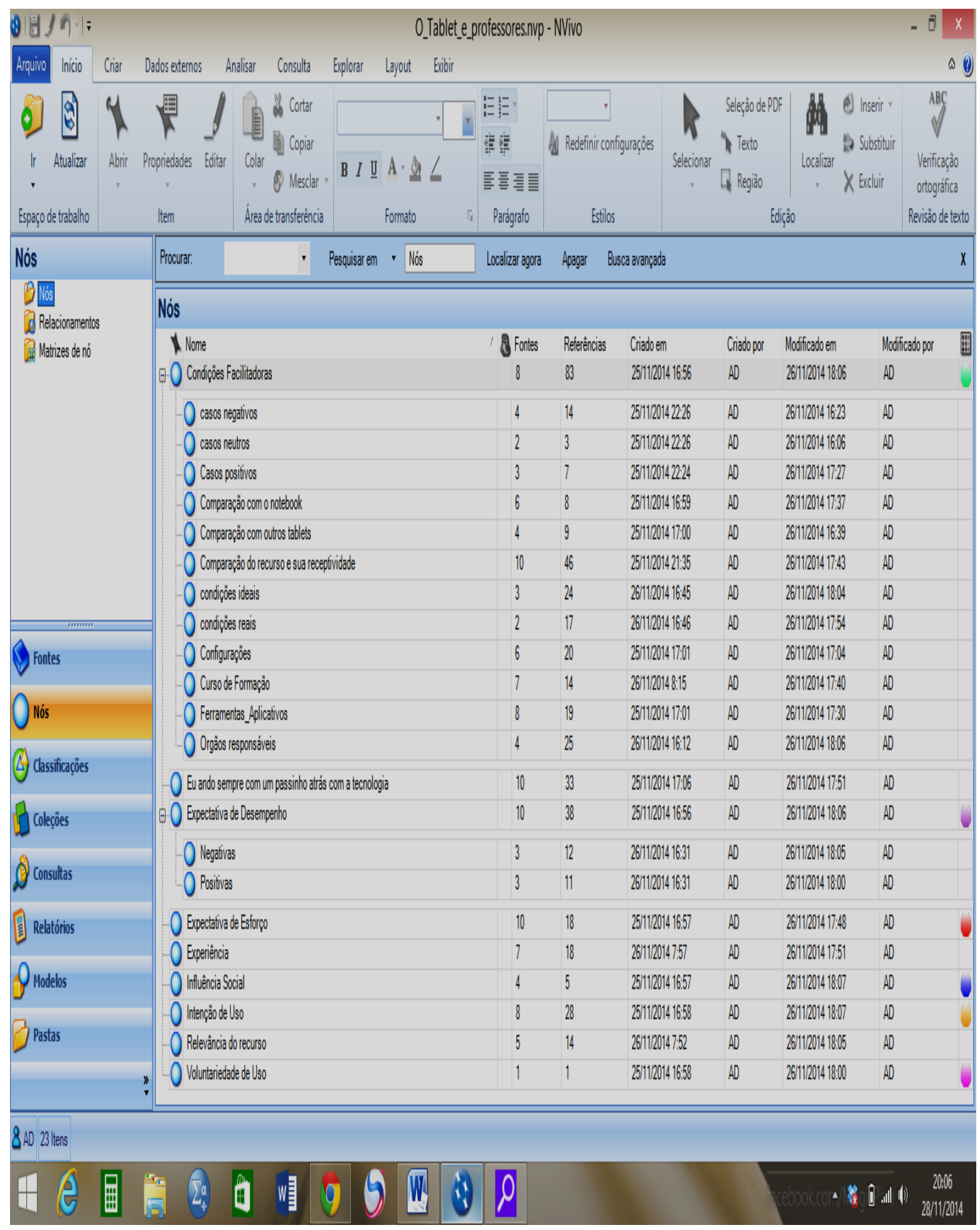

Fonte: Retirada do computador pessoal da pesquisadora, uma das telas do projeto no software Nvivo

Apesar da extensa estruturação de categorias (nós), optou-se por dedicar atenção aos constructos presentes na teoria UTAUT: determinantes e moderadores (exceto idade e gênero). Outras categorias surgiram pela necessidade de agrupar semelhanças nas falas, são 
elas: a) Eu ando sempre com um passinho atrás com a tecnologia; b) relevância do recurso (no nosso caso específico, o Tablet Educacional), mas não serão exploradas neste estudo.

\subsubsection{Análise horizontal ou transversal}

No segundo momento da exploração do recurso tecnológico para análise qualitativa temos a análise horizontal ou transversal, que sintetiza e relativiza as constâncias, semelhanças, regularidades das palavras mais citadas. Pode-se notar que de acordo com a figura 7, a frequência dessas palavras em todo o material das entrevistas reflete os termos principais da pesquisa: tablet e professor. Atentamos:

Figura 12 - Nuvens de Palavras mais citadas na pesquisa qualitativa no Nvivo

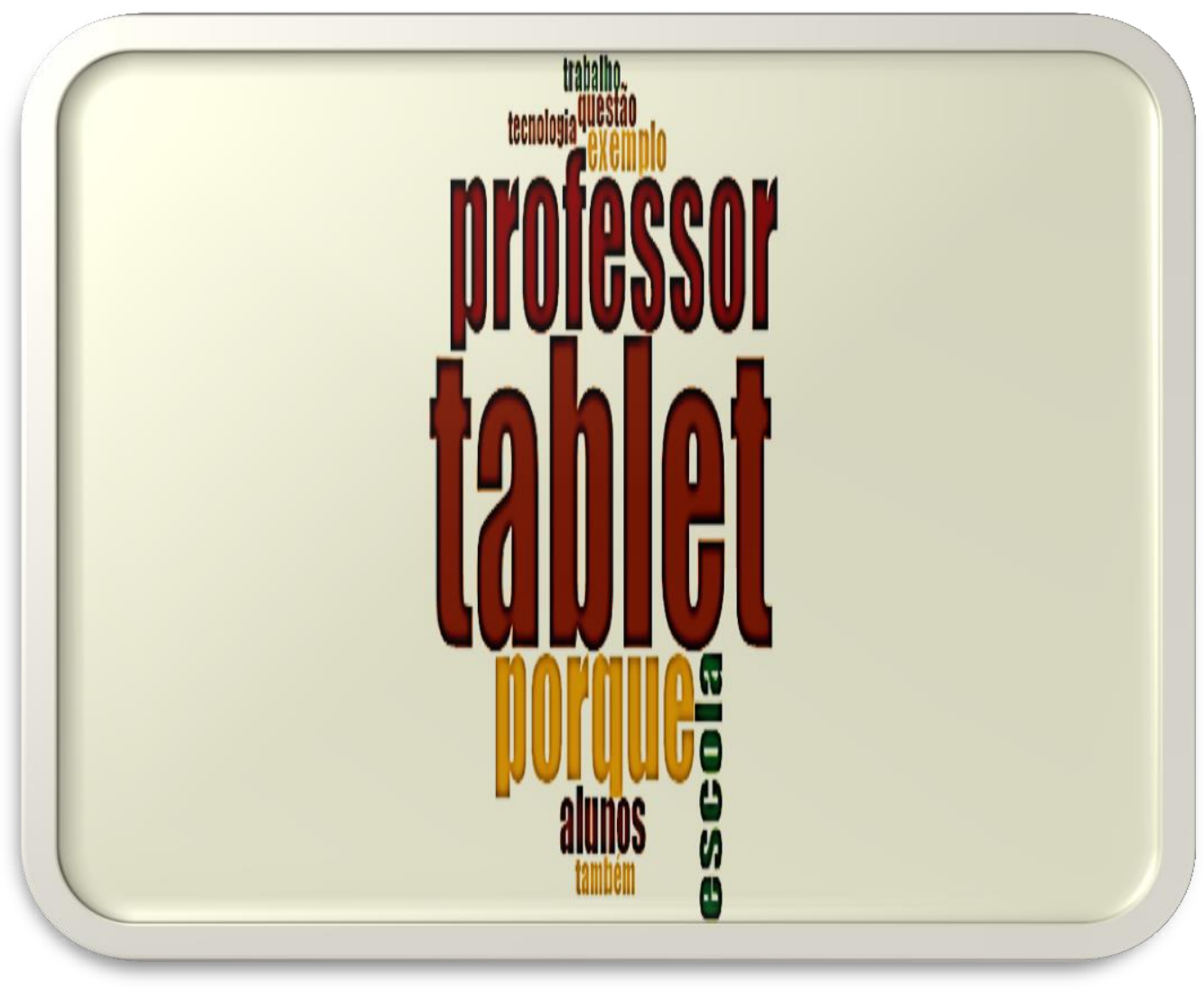

Fonte: Figura originada pelo software Nvivo com os dados coletados nas entrevistas

Conforme mencionado, os termos de maior evidência na nuvem de palavras foram professor e tablet. No entanto, os termos adjacentes apresentam inferências como: a inserção desse recurso na escola também deve prever o outro protagonista do ensino, alunos, para que haja maior interação entre eles, permitindo liberdade além dos horários preestabelecidos no ambiente escolar. Outra questão subjacente se refere a exemplos de sucesso que servem de 
espelho e motivação para o uso dessa tecnologia. Todas essas deduções foram referendadas pelas falas ${ }^{22}$ dos entrevistados:

"Então, essa ferramenta de certa fica forma um pouco restrita a muitos professores porque eles alegam que não utilizam isso porque nem todos os alunos tem acesso." (P2- Questão 04).

"E não tinha como utilizar conjuntamente com o aluno usando esse tablet." (P7Questão 04).

"que ferramentas, que programas, que aplicativos, conteúdos que possa usar e fazer isso com interatividade com os alunos" (P3- Questão04).

"Porque não vai me adiantar o tablet ou qualquer outra ferramenta que eu puder levar pra sala de aula e não poder compartilhar isso com os alunos." (P3- Questão $08)$.

"A gente tem poucas experiências e essas experiências também não são divulgadas. Eu acho que deixa a desejar neste sentido." (P4- Questão12)

\subsubsection{Análise Cluster}

Outra representação obtida pelo Nvivo foi segundo a Análise de Cluster. Esta análise gera agrupamentos com estruturas equiparadas em uma organização. Notemos na figura 8:

\footnotetext{
${ }^{22}$ A identificação de cada fala encontra-se no final sinalizava com a letra P referente a Professor seguida de uma numeração que vai de 1 a 7 , correspondente aos 7 entrevistados nesta etapa e ainda, traz em qual questão foi mencionada.
} 
Figura 13 - Análise de Cluster obtida pelo Nvivo

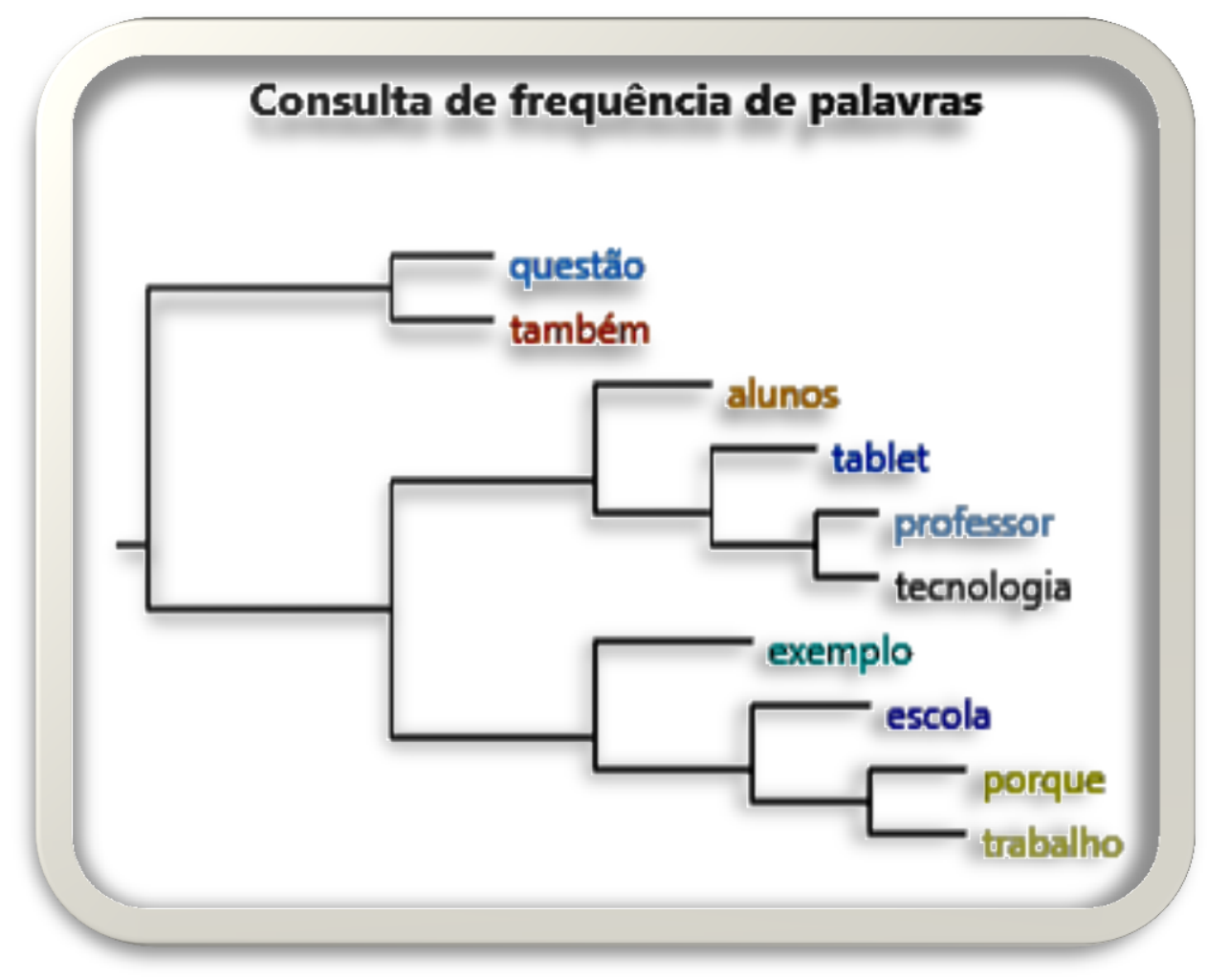

Fonte: Figura originada pelo software Nvivo com os dados coletados nas entrevistas

Essa análise é utilizada normalmente na fase inicial. E neste estudo podem-se constatar três níveis de agrupamentos:

Primeiro: O termo questão sobressai, inferindo para o problema ou para a dimensão ou grau de importância dada pelos pesquisados ao assunto desta pesquisa. Observemos nos trechos abaixo:

“... até então, eu não tinha tablet, não tinha planos de comprar para uso pessoal. Eu ando sempre com um passinho atrás com a tecnologia." (P1- Questão 1).

“... eu percebi diferença em relação a alguns programas, a questão do acesso, a resolução de tarefas, de atividades. Então, realmente eu notei a diferença. [...] Esse fornecido pela Secretaria, eu achei mais difícil" (P5- Questão 1).

"Praticamente todos os colegas com quem eu conversei que tem o domínio da informática, que são pessoas, usuárias de várias tecnologias, todas elas relataram a questão das limitações e dificuldades do tablet." (P5- Questão 3).

“... eu vejo o tablet mais como objeto de ostentação.” (P6- Questão 3). 
"muitos professores alegaram quando receberam o tablet que tinham dificuldade no manuseio [...]. Muitos professores mostraram resistentes a isso. Ou por não ter conhecimento em informática ou por nunca manusearam um tablet ou não tinham boa noção da parte tecnológica daquilo que até onde ele poderia ir com esse tablet." (P2- Questão 4).

“... eu acho que não houve um estudo prévio, nem da Secretaria, nem do Governo Federal pra ver a utilidade efetiva do uso do tablet." (Questão 4 - P3).

"Na verdade, o tablet de uma forma geral, ele nunca foi um atrativo pra mim. [...] Eu acho assim muito modismo." (Questão 1- P6).

Segundo: Professor e alunos diante da tecnologia no seu contexto e sua relação com as mesmas. A tecnologia em questão é o tablet, mas os excertos estendem a outras TDIC, vejamos:

"Nós nascemos numa geração que teve muitos recursos tecnológicos, mas nós entramos no mundo tecnológico já na adolescência, adultos praticamente. Os nossos filhos não, eles são nativos digitais. Então, eles têm um domínio excepcional, e o domínio deles nas tecnologias até as redes neurais de formação conceitual é diferente." (Questão 4 - P5).

"ele (professor) precisa fazer um trabalho coletivo e o aluno também tem que ter esse recurso." (Questão 4- P7).

"não importa o recurso tecnológico que o professor use em sala de aula, se ele não tiver uma boa metodologia para a utilização desse recurso, é em vão esse uso da tecnologia.” (Questão 5- P2).

"você poderia aproveitar essa facilidade que eles (alunos) têm para questões digitais, usar isso em seu favor na questão da disciplina." (Questão 5- P3)

Terceiro: exemplos de sucesso de uso com essa tecnologia na escola efetivamente, para que de fato haja um porquê no trabalho pedagógico, ou incentivo para outras práticas com seu uso. Esse é um dos anseios dos nossos entrevistados, mas os fragmentos retratam uma realidade distante da desejada:

"Peguei para ver se tinha condições de tornar as aulas melhores planejadas com o uso do aparelho eletrônico. Mas infelizmente não funcionou.” (Questão 3- P7).

"Não existem programas para serem utilizados em sala de aula e no geral, o que a gente consegue fazer com ele é substituir talvez o vídeo cassete, alguns vídeos que eram salvos em CD” (Questão 4- P4).

"você não ter material para incorporar dentro daquele equipamento para utilizar. Então, muitas vezes, acredito que o professor fica totalmente perdido." (Questão 4- P6). 
"Eu até tentei, mas não consegui acessar nada que poderia me ajudar, né, na minha aplicabilidade dentro de sala de aula." (Questão 5- P6)

"o tablet pode ajudar na organização diária do professor em suas atividades, mas não que vai fazer diferença no tratamento pedagógico dos assuntos da aula dele." (Questão 5-P1).

Esses foram alguns recursos de análise qualitativa do software, percorridos e que já apontam informações relevantes à pesquisa.

\subsubsection{As categorias e os construtos da teoria UTAUT}

A fase seguinte irá abordar algumas categorias (nós, denominação desse momento pelo software) criadas no programa Nvivo para esse estudo e as possíveis inferências advindas do mesmo. Friso que a apresentação a partir deste momento segue o padrão do software Nvivo, em que primeiramente traz dados de localização e dados quantitativos. Exemplificados a seguir:

Local do dado: Exemplo: <Internas\\Quadro13_Questao13>.Ou seja, essa informação está no projeto criado dentro do programa(internas) e encontra-se no quadro 13 , questão 13 .

Quantidade de referências tipificadas neste nó: § 4 referências codificadas

Grau de cobertura geral: [11,43\% Cobertura]

* $\mathrm{N}^{\mathrm{o}}$ da referência do destaque e seu grau de cobertura individual no nó: Referência $1-3,12 \%$ Cobertura

Em seguir, as falas dos entrevistados são exibidas em um quadro. E dando continuidade, prosseguirei com a base dos quatros constructos determinantes da teoria UTAUT que foram validados nesta pesquisa para nossas análises qualitativas. Vamos a elas:

\subsubsection{Condições Facilitadoras:}

A primeira categoria (nó) explicitada refere-se às Condições Facilitadoras. Na teoria UTAUT, esse constructo possui influência direta na intenção de uso da tecnologia, no nosso caso o Tablet Educacional. Para os nossos entrevistados são consideradas condições facilitadoras, a compatibilidade do recurso com outros, uma formação para o uso dessa tecnologia e infraestrutura adequada. Para apresentar os dados obtidos, centrei nos casos positivos em relação ás condições facilitadores e logo em seguida, nos casos negativos 
apontados pelos entrevistados. Destaque a seguir ao curso de formação do projeto, uma condição relevante e muito citada pelos nossos entrevistados. Observações que retratam a vivência e expectativas. E finalizando essa categoria, trago um quadro comparativo com as condições reais e as condições ideais mencionados por nossos pesquisados. Vejamos cada um deles abaixo:

a) Casos positivos: retratam alguns possíveis usos (exemplos práticos) do tablet como ferramenta pedagógica e em sala de aula na visão do professor que foram evidenciadas em 10 referências, nas questões 03, 05 e 13. Sendo que a questão 13 aborda diretamente a forma de ensino-aprendizagem. Segue alguns excertos:

<Internas \Quadro13_Questao13> - § 4 referências codificadas [11,43\% Cobertura]

Referência 1 - 3,12\% Cobertura

\begin{tabular}{|l|l|}
\hline P2 & $\begin{array}{l}\text { "uma coisa que seria importante a gente está fazendo é resolução de } \\
\text { questões online, simultaneamente, todos fazendo a mesma prova." }\end{array}$ \\
\hline
\end{tabular}

Referência $2-2,49 \%$ Cobertura

\begin{tabular}{|l|l|}
\hline P4 & Uma adaptação que eu já fiz foi essa de incluir os vídeos que eu
\end{tabular} passava no $\mathrm{CD}$, usava o vídeo cassete.

Referência 3 - 5,20\% Cobertura

\begin{tabular}{|l|l|}
\hline P5 & "o que nós fazemos são atividades de simulação, que como minha área é \\
& química, nós fazemos atividades de experimentação, simulação, \\
& $\begin{array}{l}\text { principalmente de situações, contextos que nós não podemos realizar } \\
\text { em sala de aula." }\end{array}$ \\
\hline
\end{tabular}

$<$ Internas $\backslash$ Quadro3_Questao3> - $\$ 5$ referências codificadas [16,47\% Cobertura]

Referência 1 - 2,95\% Cobertura

\begin{tabular}{|l|l|}
\hline P1 & $\begin{array}{l}\text { "partindo de uma situação que você não tem nada, de repente você recebe } \\
\text { alguma coisa razoavelmente boa pra começar." }\end{array}$ \\
\hline
\end{tabular}




\begin{tabular}{|l|l|}
\hline P4 “.. algumas pessoas ficaram bastante empolgadas. Eu me lembro porque elas \\
\\
não tinham o hábito de tá utilizando o computador, então acharam \\
bastante interessante."
\end{tabular}

Referência 5 - 6,33\% Cobertura

\begin{tabular}{|l|l|}
\hline P5 & $\begin{array}{l}\text { “... por outro lado, existem professores que não tinham acesso ao tablet e não } \\
\text { tinham também nenhum desses recursos, gostaram de ter o tablet. Pelo } \\
\text { menos começaram a mexer, começaram a usar. Ou seja, ele é significativo } \\
\text { para aquele que nunca teve... de certa forma ele está sendo incluído } \\
\text { digitalmente.” }\end{array}$ \\
\hline
\end{tabular}

b) Casos negativos: foram identificadas em 4 fontes ${ }^{23}$ com 14 referências significativas, que destacam uma postura maior de recusa do recurso pela maioria dos entrevistados e ainda, confirma que esse constructo alterou a influência para o uso do tablet, negativamente. Segue alguns registros:

\section{<Internas \Quadro3_Questao3>-§ 7 referências codificadas [12,81\% Cobertura]}

Referência $1-3,87 \%$ Cobertura

\begin{tabular}{|l|l|}
\hline P1 & $\begin{array}{l}\text { "Esses colegas que reclamavam muito gostam muito do blá-blá pelo fato de } \\
\text { não saberem nem usar o que eles já tinham naquele momento (eles não } \\
\text { sabiam)." }\end{array}$ \\
\hline
\end{tabular}

Referência 2 - 0,81\% Cobertura

\begin{tabular}{|l|l|}
\hline P3 & "o que eu ouvi foram reclamações." \\
\hline
\end{tabular}

\section{Referência 3 - 2,22\% Cobertura}

\footnotetext{
${ }^{23}$ As quatro fontes referem-se às questões $\mathrm{n}^{\circ} 03,04,05$ e 10 do protocolo de entrevista utilizado nesta pesquisa (ver anexo, apêndice C). Essas fontes podem ser visualizadas neste espaço da dissertação no campo local do dado gerado pelo programa Nvivo.
} 


\begin{tabular}{|l|l|}
\hline P3 & $\begin{array}{l}\text { "Eles perguntaram como fariam para devolver porque não queriam } \\
\text { continuar com ele mais." }\end{array}$ \\
\hline
\end{tabular}

\section{Referência 4 - 0,73\% Cobertura}

\begin{tabular}{|l|l|}
\hline P4 & "as pessoas poucos utilizavam." \\
\hline
\end{tabular}

\section{Referência 5 - 1,10\% Cobertura}

\begin{tabular}{|l|l|}
\hline P4 & "mas depois não fizeram nenhum tipo de uso." \\
\hline
\end{tabular}

\section{Referência 6 - 3,01\% Cobertura}

\begin{tabular}{|l|l|}
\hline P5 & $\begin{array}{l}\text { "pessoas, usuárias de várias tecnologias, todas elas relataram a questão das } \\
\text { limitações e dificuldades do tablet." }\end{array}$ \\
\hline
\end{tabular}

\section{Referência 7 - 1,07\% Cobertura}

\begin{tabular}{|l|l|}
\hline P6 & "eu não vejo nenhum colega usando o tablet." \\
\hline
\end{tabular}

\section{<Internas\\Quadro4_Questao4> - $§ 2$ referências codificadas [3,00\% Cobertura]}

Referência 1 - 1,97\% Cobertura

\begin{tabular}{|l|l|}
\hline P3 "nas duas escolas em que eu trabalho, você não consegue acessar se quer \\
& $\begin{array}{l}\text { internet na sala de aula. Então, veja a quantidade de problemas nós temos } \\
\text { para utilizar." }\end{array}$ \\
\hline
\end{tabular}

<Internas \\Quadro5_Questao5> - § 4 referências codificadas [6,82\% Cobertura]

Referência 1 - 1,48\% Cobertura

\begin{tabular}{|l|l|}
\hline P1 & $\begin{array}{l}\text { "nós tivemos um probleminha de incompatibilidade, o nosso diário } \\
\text { eletrônico não rodava bem no tablet." }\end{array}$ \\
\hline
\end{tabular}




\begin{tabular}{|l|l|}
\hline P5 & $\begin{array}{l}\text { "o professor que usa, que já usa a tecnologia, o tablet do GDF, eu não vejo } \\
\text { sendo usado em sala, eu vejo outros tablets, mais modernos, com melhores } \\
\text { aplicativos , com a memória mais potente para aula." }\end{array}$ \\
\hline
\end{tabular}

Referência 3 - 1,77\% Cobertura

\begin{tabular}{|l|l|}
\hline P6 & $\begin{array}{l}\text { "Eu até tentei, mas não consegui acessar nada que poderia me ajudar, né, } \\
\text { na minha aplicabilidade dentro de sala de aula." }\end{array}$ \\
\hline
\end{tabular}

\section{Referência 4 - 0,62\% Cobertura}

\begin{tabular}{|l|l|}
\hline P7 & "Mas esse tablet em si não funcionou não." \\
\hline
\end{tabular}

c) Curso de Formação: faz parte de uma das condições mais importantes para o uso efetivo do recurso tecnológico, pois sem o conhecimento do mesmo ou o domínio da tecnologia, dificilmente o usuário irá se aventurar a usá-lo no seu ambiente de trabalho. Os registros pertinentes a essa condição foram encontrados em 7 fontes ${ }^{24}$. Abaixo alguns fragmentos que ilustram a percepção do professor:

$<$ Internas \Quadro10_Questao10> - § 3 referências codificadas [5,98\% Cobertura]

Referência 1 - 1,48\% Cobertura

\begin{tabular}{|l|l|}
\hline P5 & $\begin{array}{l}\text { "Poderia vir novamente atividades menores, pontuais, cursos menores } \\
\text { pra dar continuidade." }\end{array}$ \\
\hline
\end{tabular}

Referência 2 - 1,82\% Cobertura

\begin{tabular}{|l|l|}
\hline P6 & $\begin{array}{l}\text { eu acho que o aprendizado vai ser muito mais na prática , você } \\
\text { manuseando e aprendendo, manuseando e aprendendo. }\end{array}$ \\
\hline
\end{tabular}

\footnotetext{
${ }^{24}$ As sete fontes referem-se às questões $\mathrm{n}^{\circ} 04,05,08,10,11,12,14$, com 14 referências, do protocolo de entrevista utilizado nesta pesquisa (ver anexo, apêndice C). Essas fontes podem ser visualizadas neste espaço da dissertação no campo local do dado gerado pelo programa Nvivo.
} 


\begin{tabular}{|l|l|}
\hline P7 & $\begin{array}{l}\text { eu acho que o professor precisaria ser ouvido mesmo } \\
\text { individualmente, com perguntas objetivas, nada de perguntas evasivas, } \\
\text { igual a gente ver muito nesses cursos aí. }\end{array}$ \\
\hline
\end{tabular}

<Internas $\mid$ Quadro12_Questao12〉 - § 1 referência codificada [4,55\% Cobertura]

\section{Referência 1 - 4,55\% Cobertura}

\begin{tabular}{|l|l|}
\hline P3 & $\begin{array}{l}\text { eu acho também que teria que haver uma formação pro professor. Eu } \\
\text { acho que a gente partir sempre do princípio de que ah todo mundo hoje } \\
\text { tem acesso à tecnologia, então, todo mundo sabe. Eu acho que isso não } \\
\text { é verdade. Você pode até saber mandar um email, receber um e-mail, } \\
\text { mas você não tem quando pega um aplicativo interessante e você } \\
\text { pensa assim: vamos trabalhar com os alunos e fazer um trabalho } \\
\text { legal. Eu acho que aqui nós não temos essas condições. }\end{array}$ \\
\hline
\end{tabular}

<Internas \\Quadro14_Questao14> - § 3 referências codificadas [2,42\% Cobertura]

Referência $1-0,85 \%$ Cobertura

\begin{tabular}{|l|l}
\hline P1 & "A formação inicial e continuada neste sentido de adaptação a novas
\end{tabular} tecnologias devem continuar."

Referência 3 - 0,81\% Cobertura

\begin{tabular}{|l|l|}
\hline P1 & $\begin{array}{l}\text { "De uma maneira geral a gente não deve parar, o curso de formação } \\
\text { continuada deve continuar." }\end{array}$ \\
\hline
\end{tabular}

$<$ Internas \QQuadro4_Questao4〉 - § 3 referências codificadas [2,70\% Cobertura]

Referência $1-0,32 \%$ Cobertura

\begin{tabular}{|l|l|}
\hline P3 & $\begin{array}{l}\text { Na minha perspectiva, o curso foi mal organizado. Não sei o nível, mas pelo } \\
\text { o que os professores falavam, o nível de organização do curso, na verdade, nos } \\
\text { detalhes para se trabalhar o tablet }, \text { pelo que eu senti, o curso foi mais para }\end{array}$ \\
\hline
\end{tabular}




\begin{tabular}{|l|l|}
\hline & $\begin{array}{l}\text { você manusear o tablet, mas não apresentaram , nós temos esse aplicativo , } \\
\text { vocês vão trabalhar assim, assim, assim. Nós estamos oferecendo essa opção. } \\
\text { Não teve isso. }\end{array}$ \\
\hline
\end{tabular}

Referência 3 - 1,56\% Cobertura

\begin{tabular}{|l|l|}
\hline P7 & $\begin{array}{l}\text { O professor tinha e de certo não ia utilizar ele porque as dificuldades eram } \\
\text { muito grandes e os cursos não tiravam as dúvidas. }\end{array}$ \\
\hline
\end{tabular}

<Internas\Quadro8_Questao8> - § 1 referência codificada [1,25\% Cobertura]

Referência $1-1,25 \%$ Cobertura

\begin{tabular}{|l|l}
\hline P1 & "o curso de formação foi pra mim muito importante. Muito válido!"
\end{tabular}

d) Condições Reais e Condições Ideais: essas categorias foram instigadas em uma das questões da entrevista, a $n^{\circ}$ 12. Segue abaixo falas representativas de alguns itens mencionados pelos mesmos.

Quadro 5 - Condições para o uso do Tablet no contexto da pesquisa

\section{Condições para o uso do Tablet no contexto da pesquisa}

\begin{tabular}{|c|c|c|}
\hline & Condições reais e atuais & Condições ideias \\
\hline Internet & $\begin{array}{l}\text { "A nossa internet era muito } \\
\text { precária, nós tínhamos } \\
\text { basicamente rede wireless só } \\
\text { no corredorzinho da direção } \\
\text { que pegava mais ou menos } \\
\text { na sala dos professores e na } \\
\text { sala da reunião pedagógica. } \\
\text { Fora dali basicamente não } \\
\text { funcionava." (P1). }\end{array}$ & $\begin{array}{l}\text { "Nós precisamos é ter na } \\
\text { escola é uma internet muito } \\
\text { boa, com boa capacidade, } \\
\text { que consiga atender, ou ter } \\
\text { pontos repetidores." (P5). }\end{array}$ \\
\hline
\end{tabular}




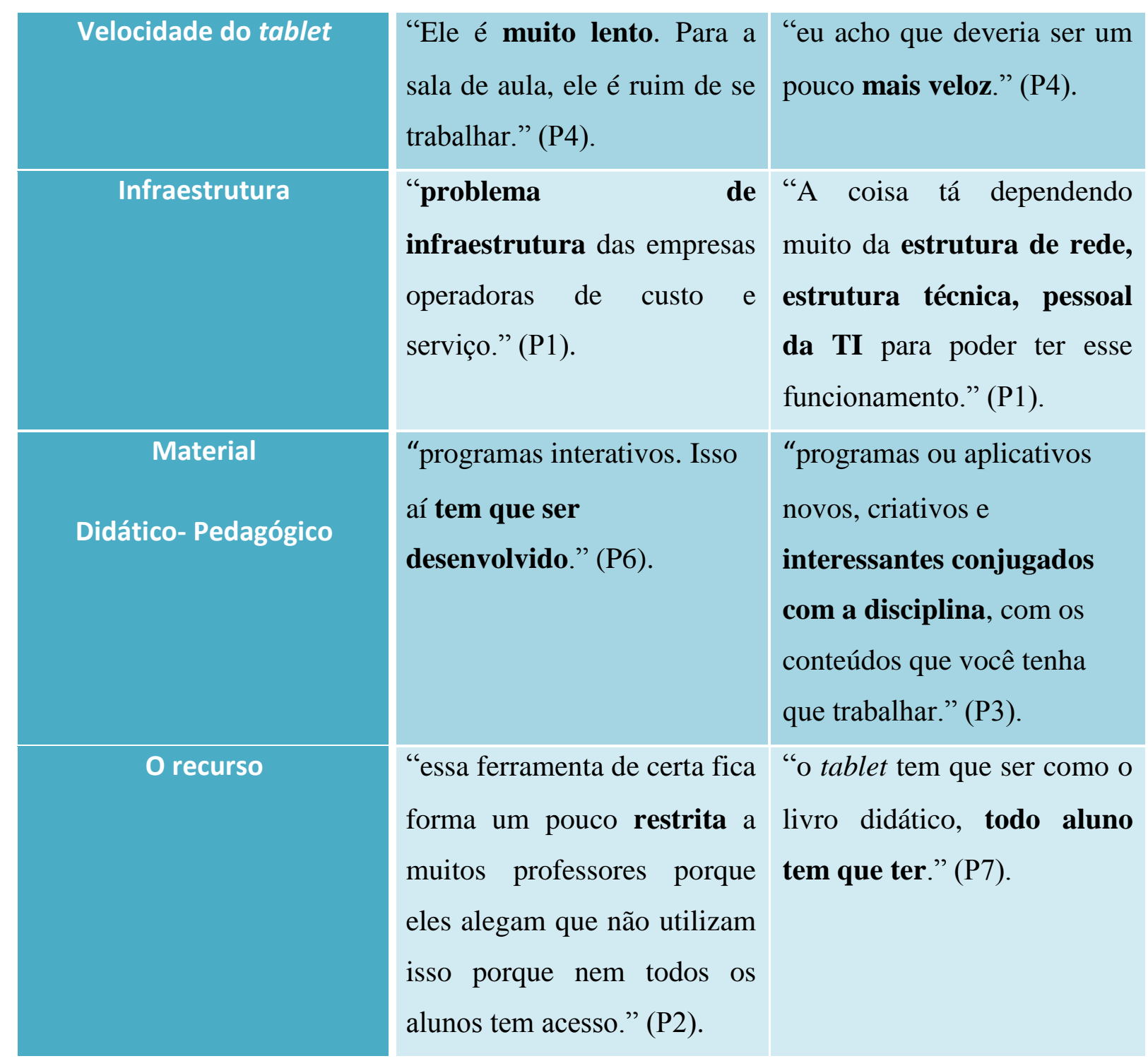

Fonte : Criado pela pesquisadora com os dados coletados durante as entrevistas

\subsubsection{Expectativa de Esforço:}

A Expectativa de Esforço é um constructo da teoria UTAUT que identifica o grau que o individuo associa o recurso tecnológico à facilidade de uso. E na entrevista alguns trechos explicitam a visão do público em relação ao tablet no contexto educacional. Vejamos:

<Internas\\uadro1_Questao1> - §5 referências codificadas [6,31\% Cobertura]

Referência 1 - 1,57\% Cobertura

\begin{tabular}{|l|l|}
\hline P3 "ninguém achou utilidade pro Tablet, na nossa área: sociologia, filosofia ou \\
história."
\end{tabular}




\begin{tabular}{|l|l|}
\hline P3 & $\begin{array}{l}\text { "juntando todo esse processo eu preferi não pegar o tablet. } \text { Então, eu não } \\
\text { utilizei observando e acompanhando os colegas que estavam com ele na mão." }\end{array}$ \\
\hline
\end{tabular}

\section{Referência 3 - 0,66\% Cobertura}

\begin{tabular}{|l|l|}
\hline P4 & "Então, o uso dele é mais difícil, né." \\
\hline
\end{tabular}

<Internas\\Quadro14_Questao14> - § 2 referências codificadas [2,78\% Cobertura]

\section{Referência 1 - 1,64\% Cobertura}

\begin{tabular}{|l|l|}
\hline P2 & $\begin{array}{l}\text { "Acredito que seja uma ferramenta importante. É uma ferramenta que } \\
\text { vai ajudar no trabalho do professor em sala de aula. Acredito que o } \\
\text { ensino possa melhorar com o uso dessa modernidade." }\end{array}$ \\
\hline
\end{tabular}

<Internas\\Quadro3_Questao3> - § 1 referência codificada [4,34\% Cobertura]

Referência 1 - 4,34\% Cobertura

\begin{tabular}{|l|l|}
\hline P7 & $\begin{array}{l}\text { "Peguei para ver se tinha condições de tornar as aulas melhores planejadas } \\
\text { com o uso do aparelho eletrônico. Mas infelizmente não funcionou, pra mim } \\
\text { não funcionou não." }\end{array}$ \\
\hline
\end{tabular}

<Internas\\Quadro4_Questao4> - § 2 referências codificadas [5,05\% Cobertura]

Referência $1-0,81 \%$ Cobertura

\begin{tabular}{|l|l|}
\hline P2 & "muitos professores enxergaram esse tablet para utilização do DICEL." \\
\hline
\end{tabular}

Referência 2 - 4,24\% Cobertura

\begin{tabular}{|l|l|}
\hline P5 & "Eu acho que no nosso caso o fato das dúvidas serem, aparecerem em relação \\
& ao trabalho é porque o professor tem medo de usar o tablet, outra coisa, dá \\
trabalho, tem que estudar, tem que aprender, tem que tirar horas que ele não \\
ia fazer nada ou ia fazer outra atividade para sentar, focar e aprender a mexer
\end{tabular}


naquele tablet. Então, exige dedicação."

\section{Referência 2 - 2,97\% Cobertura}

\begin{tabular}{|c|c|}
\hline $\mathrm{P} 4$ & $\begin{array}{l}\text { "eu percebi alguns colegas que não tinham o hábito de usar o computador, ao } \\
\text { receberem o tablet, eles perceberam semelhanças dele com os aparelhos } \\
\text { celulares, então, tiveram facilidades de manusear ali." }\end{array}$ \\
\hline
\end{tabular}

A maioria dos relatos apontam dificuldades para a utilização do tablet no ambiente escolar. Há, porém, relatos que demonstram uma visão otimista desse recurso e de possíveis usos produtivos no contexto escolar. Há ainda uma associação de facilidade com o conhecimento do recurso tecnológico e sua aceitação. Essa evidência complementa os dados levantados na versão preliminar do questionário quanto à familiaridade do recurso e infere que esse constructo possui influência no seu uso efetivo, na proporção direta do conhecimento acerca do mesmo.

\subsubsection{Expectativa de Desempenho/ Performance:}

Neste momento a intenção é analisar o quanto o professor acredita que essa tecnologia, o Tablet Educacional, possa ajudá-lo no seu desempenho, em uma determinada tarefa. E diante das falas abaixo se pode perceber nitidamente que o professor não considera o tablet um recurso que possa melhorar o seu desempenho. Segue algumas exemplificam:

<Internas\Quadro11_Questao11> - § 4 referências codificadas [7,39\% Cobertura]

Referência 2 - 3,50\% Cobertura

\begin{tabular}{|l|l|}
\hline P7 & "Que a gente tem um inimigo cruel na educação que é a tecnologia \\
& $\begin{array}{l}\text { na frente da escola. E o aluno quando chega na sala de aula, ele abre a } \\
\text { internet , baixa vídeos interessantes pra ele e coisas que não tem nada a } \\
\text { ver com a realidade da aula, mas eles não estão nem aí." }\end{array}$ \\
\hline
\end{tabular}

<Internas \QQuadro12_Questao12> - § 1 referência codificada [1,80\% Cobertura]

Referência 1 - 1,80\% Cobertura 


\begin{tabular}{|c|c|}
\hline $\mathrm{P} 4$ & $\begin{array}{l}\text { "não se definiu qual a função desses tablets. Se é para o professor } \\
\text { resolver questões burocráticas, ou se é para professor usar como } \\
\text { ferramenta de ensino." }\end{array}$ \\
\hline
\end{tabular}

Referência 4 - 0,73\% Cobertura

\begin{tabular}{|l|l|}
\hline P4 "acho que não vou ter muitos resultados em sala de aula nem como \\
propaganda também."
\end{tabular}

Referência 5 - 2,32\% Cobertura

\begin{tabular}{|l|l|}
\hline P7 & "Algo que pudesse responder os anseios do professor. Esse tablet que \\
& estamos falando aqui, ele não atendeu em nada, assim. Do meu ponto \\
& de vista, ele não atendeu em nada porque eu não consegui fazer nada, \\
& nem os exercícios do curso, eu não consegui fazer nele." \\
\hline
\end{tabular}

<Internas \\uadro5_Questao5>-§ 2 referências codificadas [3,03\% Cobertura]

Referência $1-1,25 \%$ Cobertura

\begin{tabular}{|l|l|l}
\hline P1 & "Mas em termos de melhorar o desempenho, acredito que não tenha grande
\end{tabular} influencia não."

Referência 2 - 1,77\% Cobertura

\begin{tabular}{|l|l|}
\hline P6 & $\begin{array}{l}\text { "Eu até tentei, mas não consegui acessar nada que poderia me ajudar, né, } \\
\text { na minha aplicabilidade dentro de sala de aula." }\end{array}$ \\
\hline
\end{tabular}

<Internas\\uadro8_Questao8> - § 1 referência codificada [1,96\% Cobertura]

Referência 1 - 1,96\% Cobertura

\begin{tabular}{|l|l|}
\hline P3 & $\begin{array}{l}\text { "Eu não vejo hoje qual a instrumentação que a secretaria dá, eu não } \\
\text { vejo se quer para preparar aulas." }\end{array}$ \\
\hline
\end{tabular}




\subsubsection{Influência Social:}

Nesta categoria, 6 fontes apresentaram 15 referências relativas ao tema. Uma questão intrigante apresentada no primeiro instrumento: o questionário, foi o deslocamento de alguns itens que estavam relacionados a pessoas e que inicialmente eram considerados como Influência Social, para o constructo das Condições Facilitadoras. Constatado esse deslocamento, o aprofundamento se fez necessário para entender essa ação. Alguns destaques para análise:

<Internas \\uadro10_Questao10>-§ 5 referências codificadas [8,42\% Cobertura]

Referência 1 - 1,19\% Cobertura

\begin{tabular}{|l|l|}
\hline P2 & $\begin{array}{l}\text { "eu acredito que dependendo do órgão que for citado acaba } \\
\text { dificultando sim." }\end{array}$ \\
\hline
\end{tabular}

Referência 2 - 1,17\% Cobertura

\begin{tabular}{|l|l|}
\hline P3 & $\begin{array}{l}\text { "eu não vejo na Secretaria ou por parte da EAPE um trabalho de } \\
\text { incentivo." }\end{array}$ \\
\hline
\end{tabular}

Referência 3 - 1,68\% Cobertura

\begin{tabular}{|l|l|}
\hline P3 & $\begin{array}{l}\text { "eu não sou estimulado a fazer um curso pela EAPE. Não sou porque } \\
\text { eu coloco em dúvida é qualidade, sabe." }\end{array}$ \\
\hline
\end{tabular}

Referência 4 - 2,26\% Cobertura

\begin{tabular}{|l|l|}
\hline P4 "Eu conheço pessoas lá que tem essa facilidade, tem conhecimento, que \\
\\
$\begin{array}{l}\text { se a gente tiver alguma ideia são pessoas que se colocam a } \\
\text { disposição." }\end{array}$ \\
\hline
\end{tabular}

<Internas\\Quadro9_Questao9> - § 5 referências codificadas [15,25\% Cobertura]

Referência 3 - 3,08\% Cobertura 


\begin{tabular}{|l|l|}
\hline P5 & $\begin{array}{l}\text { "A direção da escola sempre incentiva, mas o grupo de professores não } \\
\text { se sente incentivados, ou valorizados ou intencionados em usar o } \\
\text { tablet, não vejo, não percebo." }\end{array}$ \\
\hline
\end{tabular}

\section{Referência $5-3,32 \%$ Cobertura}

\begin{tabular}{|l|l|}
\hline P7 & $\begin{array}{l}\text { "Então, acho que a escola em si, a coordenação, os supervisores, o } \\
\text { pessoal da parte pedagógica tenta ajudar da melhor forma possível. O } \\
\text { problema é que a tecnologia que não ajuda." }\end{array}$ \\
\hline
\end{tabular}

Nestes trechos há indícios que auxiliam na confirmação apresentada no questionário, em que o professor visualiza essas pessoas/ órgãos como facilitadoras para as condições ideais de uso da tecnologia em seu trabalho, evidenciado nos verbos: dificultando, estimulado, ajudar; e em ações necessárias e que acabam interferindo no contexto, aqui reforçadas pelos termos nas falas acima: incentivo, disposição, valorizados.

Outra questão nesta categoria evidenciada foi como o professor se vê ao usar a tecnologia, no caso, o Tablet Educacional, perante os demais na sociedade, ou mais especificamente, no trabalho. E neste caso, o professor percebe que a tecnologia possui uma importante função: a de aproximar dois universos: imigrantes e nativos digitais, ou seja, boa parte dos professores e alunos em geral. Além de se apresentar como uma aliada para proporcionar maior interesse de seu aluno para o universo escolar. Observem nas falas abaixo: <Internas \\Quadro13_Questao13> - § 1 referência codificada [4,11\% Cobertura]

Referência $1-4,11 \%$ Cobertura

\begin{tabular}{|l|l|}
\hline P3 & $\begin{array}{l}\text { "Seria uma ferramenta muito boa que iria de encontro inclusive com } \\
\text { essa meninada que está aí, como se diz: vidrado nesta tecnologia. Veria } \\
\text { com bons olhos e usaria de boa." }\end{array}$ \\
\hline
\end{tabular}

<Internas \Quadro14_Questao14> - § 2 referências codificadas [4,31\% Cobertura]

Referência $1-2,81 \%$ Cobertura 


\begin{tabular}{|l|l|}
\hline P5 & $\begin{array}{l}\text { "a gente tem inúmeros recursos e como ele é digital, ele vive num } \\
\text { mundo virtual, então a grande sacada do professor é usar essa } \\
\text { vontade, esse interesse do aluno na área de ensinar. Para ele entender } \\
\text { que ele pode brincando, passeando, visitando determinado local, } \\
\text { aprender química ou aprender qualquer outra matéria." }\end{array}$ \\
\hline
\end{tabular}

<Internas\\Quadro2_Questao2> - § 1 referência codificada [8,68\% Cobertura]

Referência $1-8,68 \%$ Cobertura

\begin{tabular}{|l|l|}
\hline P1 & $\begin{array}{l}\text { "Nós não conseguiremos ficar fora disso, ou com o notebook, ou com o tablet, } \\
\text { ou com outra coisa, porque nós vivemos numa época que não dá mais para } \\
\text { ficar totalmente separados. A escola e as tecnologias educacionais } \\
\text { modernas." }\end{array}$ \\
\hline
\end{tabular}

Longe de expressar todos os resultados possíveis obtidos por nossos instrumentos de coleta, mas atentos a nossos objetivos desta pesquisa e cientes da dimensão das respostas acolhidas para o entendimento neste estudo, posso concluir esse capítulo e principiar às discussões dos resultados. 


\section{CAPÍTULO VII - DISCUSSÃO}

A ideia principal desta pesquisa consiste em conhecer as percepções dos professores acerca do Tablet Educacional e verificar o nível de receptividade do mesmo no contexto escolar. Neste capítulo, a base das discussões centrar-se-á nesses objetivos, respaldada pela Teoria Unificada de Aceitação e Uso da Tecnologia (UTAUT), o alicerce deste estudo.

Os resultados, tanto quantitativos quanto qualitativos, explicitam uma boa receptividade dos professores ao Tablet Educacional, bem como, às demais Tecnologias Digitais de Informação e Comunicação (TDIC) no âmbito escolar. Porém o grau de aceitação ao recurso tecnológico em evidência neste estudo não foi satisfatório quando confrontados pelos constructos determinantes analisados na teoria UTAUT. A partir desse momento, analisei os resultados obtidos de acordo com cada construto examinado nesse estudo e sua relação entre eles na busca do entendimento da questão.

Atentamos para a Voluntariedade de Uso que faz parte das Condições Facilitadoras. O professor conhece a dimensão de seu poder em utilizar ou não o Tablet Educacional, independente de órgãos ou pessoas. Ele se descobre como o responsável por essa ação, demonstrando autonomia e criticidade. No entanto, a intenção de usar o recurso tecnológico abrange a relevância desse ao seu contexto, e não há uma compreensão clara da importância do tablet para o professor desta pesquisa. Esse posicionamento pode ser devido a não avistar inovação tecnológica somente pelo uso da ferramenta. Resultado corroborado por Castells (2011), em que "a inovação tecnológica não é uma ocorrência isolada", ela vem imbuída de outros fatores como: estágio de conhecimento dessa tecnologia, um ambiente institucional que atenda a demanda, disponibilidade de talentos para definir um problema técnico e resolvê-lo, relação dos custos e dos benefícios, aprender usando e fazendo. Todos esses fatores foram mencionados por nossos pesquisados ao especular sobre a relevância do tablet e às condições para sua utilização.

Enquanto na teoria UTAUT os Fatores Moderadores mostraram-se significativos apenas quando houve a conjunção entre as variáveis idade e experiência (VENKATESH et al., 2003), neste estudo pode notar-se que, mesmo sem essas correlações, esse constructo caracterizou-se como expressivo para o uso do Tablet Educacional.

Todavia pode-se afirmar que apesar da influencia dos nativos digitais, temos diversas idades e experiências na nossa população fonte. Experiências que foram adquiridas por meio do curso de formação para o uso do recurso tecnológico, Tablet Educacional; em seu 
ambiente de trabalho ou ainda através de outros cursos ou vivências. Essas atitudes caracterizam a preocupação em se atualizar, pois, de acordo com Levy (2011), é fundamental a formação do docente deste século:

"não pode mais ser uma difusão dos conhecimentos, que agora é feita de forma mais eficaz por outros meios. Sua competência deve deslocar-se no sentido de incentivar a aprendizagem e o pensamento. O professor torna-se um animador da inteligência coletiva dos grupos que estão a seu encargo." (LEVY, 2011, p.173).

E no sentido de incentivar a aprendizagem e o pensamento, nosso professor volta-se para o universo tecnológico. Essa busca, em plena cultura digital, demonstra um indivíduo preocupado em diminuir o "hiato geracional", distância entre aqueles que nasceram antes da Era da Internet e os que cresceram no Mundo Digital (CASTELLS, 2011).

Essa ação voluntária para aprender algo novo nos remete ainda, a imersão proposta por Murray (2003) em que:

Gostamos de sair de nosso mundo familiar, do sentido de vigilância que advém de estarmos nesse lugar novo, e do deleite que é aprendermos a nos movimentar dentro dele. (...) Mas num meio participativo, a imersão implica aprender a nadar, a fazer as coisas que o novo ambiente torna possíveis. (MURRAY, 2003, p.102).

Conhecer o novo ambiente proporcionado pelas TDIC e suas potencialidades pedagógicas requer participação de todos envolvidos na escola para tornar possíveis as inovações. Essa participação é demonstrada por nossos pesquisados.

A pesquisa exibiu um resultado evidente de neutralidade por parte dos nossos pesquisados quanto à relevância do Tablet Educacional no contexto escolar. Essa característica apresentada pelos professores retrata desconfiança das novas tecnologias e poucas experiências bem sucedidas. O ritmo acelerado de inserção de novas tecnologias não permite tempo para uma análise confiante das suas relevâncias ou não. Pois, conforme Murray (2003) "as novas tecnologias estão expandindo nossas capacidades com maior rapidez do que podemos assimilar tais mudanças." (MURRAY, 2003, p.23).

Ao direcionar nosso foco no constructo Expectativa de Desempenho, nota-se que o professor pesquisado se expressou diferentemente nos instrumentos da pesquisa. Manifestação de que a crença e atitudes comportamentais divergem, porque ele acredita que o 
tablet pode ser útil ao seu desempenho profissional, porém, na prática, as manifestações são de desaprovação. Surge aqui um agir e um pensar adversos. Essa ação aparece como um dos fatores ocasionados pela revolução das tecnologias explicitada por Castells (2011), assim como a interação histórica entre transformação tecnológica, as ações sociais divergentes, novo paradigma informacional, novo período e uma complexa interação com todos esses elementos gerando várias transformações no trabalho e na sua estrutura social.

Para encontrar padrões de regularidade atrás desse cenário confuso, devemos ter paciência de abstrair camadas sucessivas de causação social para primeiro desconstruir e depois reconstruir o padrão de trabalho emergente, os trabalhadores e a organização do trabalho que caracterizam a nova sociedade informacional. (CASTELLS, 2011, p. 305).

Nesta pesquisa, pode-se inferir que o cenário apresentado por Castells (2011) da década de 1990 advindo com o amadurecimento da revolução das tecnologias permanece confuso a cada inserção tecnológica. Os resultados em relação ao recurso tecnológico tablet e o trabalho docente são explicitados na dicotomia no constructo Expectativa de Desempenho. Os momentos de desconstrução e reconstrução de conceitos e ações são naturais, experiências exitosas que validem o uso das diversas tecnologias no contexto educacional são imperativas para superar essa hesitação. De acordo com Papert (2008) o futuro da educação exige imaginação, porém no universo tecnológico esse futuro depende do ontem, ou seja, "o que você vê é o que você obtém" (PAPERT, 2008, p.40). Tal pensamento é refletido pela nossa população fonte à inovação do ensino-aprendizagem por meio de recursos tecnológicos.

Quanto ao constructo Expectativa de Esforço, a população fonte considerou a relação quanto mais conhecimento sobre recurso tecnológico aliado a familiaridade com o mesmo, o resultado será de menos esforço para utilizá-lo. Essa relação é representada aqui por meio de um elemento gráfico que permite uma visualização mais rápida, fácil e explicita a ideia plenamente: 


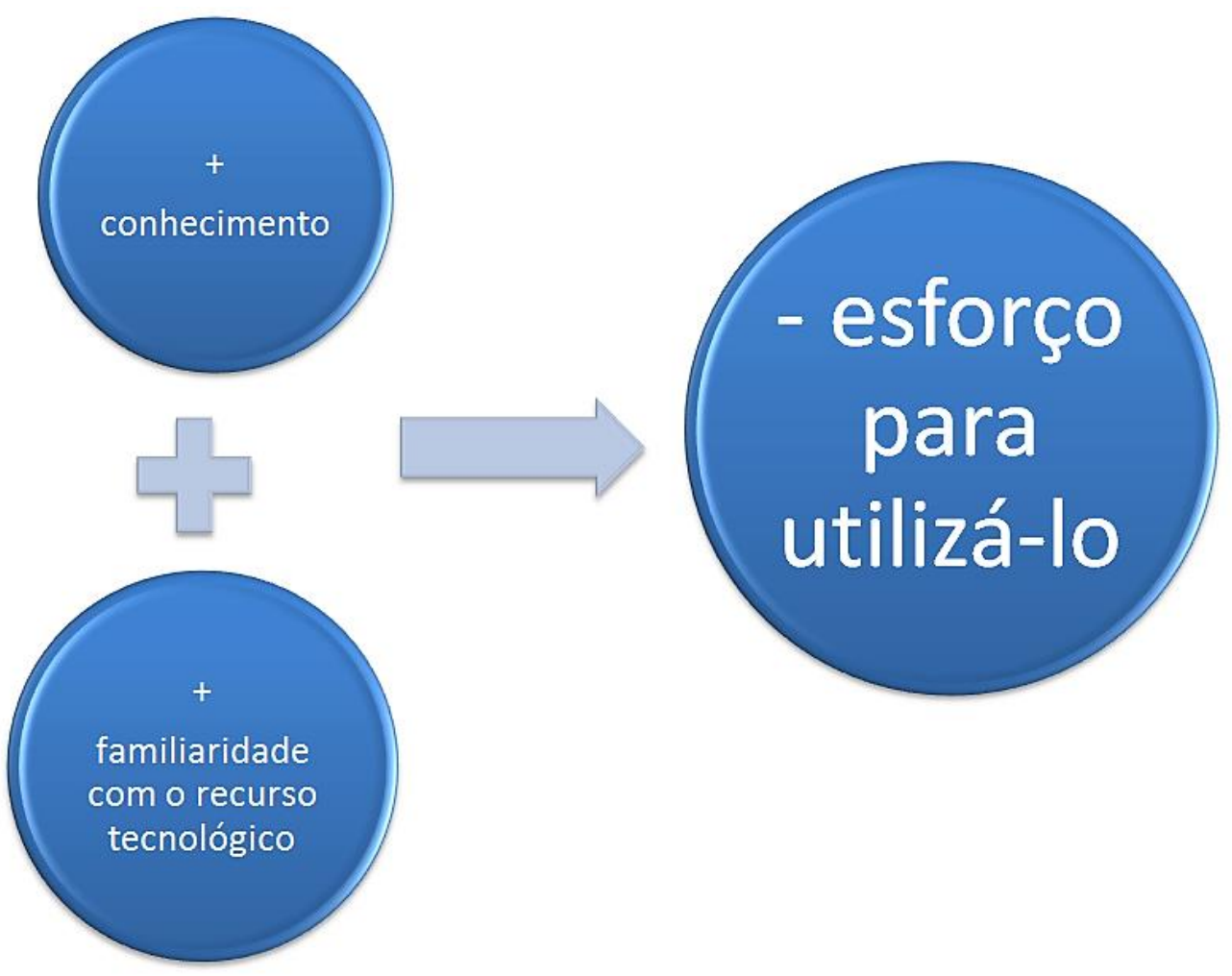

Fonte: Elaborada pela pesquisadora com base nos dados coletados

É interessante salientar que conhecer acerca do tablet com suas funcionalidades e possíveis usos, poderia ser adquirido por meio do curso de formação previsto no projeto Educação Digital. No tocante à familiaridade, o foco projeta-se para experiências com o tablet. Experiências essas vivenciadas pelos pesquisados antes ou durante o projeto. Esses dois itens influenciam diretamente o grau de esforço segundo nossos pesquisados. Há um dado controverso a teoria UTAUT, pois a formação/conhecimento é visto como Constructo Condições Facilitadoras. Esse constructo, na teoria original, tem influência direta no Comportamento de Uso e não na Intenção de Uso do usuário, diferentemente do ocorrido neste estudo. Isso pode ter ocorrido pelo fato da não aplicação do constructo: Comportamento de Uso na pesquisa, uma vez que nossos pesquisados estavam com o recurso tecnológico há pouco tempo. Na Turquia, a Literacia em informática também se destacou em relação aos demais construtos sugerindo alteração do seu lugar nos fatores moderadores para os determinantes (GÖĞÜŞ et all. 2012).

No entanto, o público desta pesquisa, que considera o conhecimento fundamental para utilizar o Tablet Educacional, a partir dos números finais de concluintes do curso de formação, nos sugere a rejeição a essa ação. Essa postura nos remete à abordagem da 
aprendizagem, em que conhecimento e experiências são necessários. Todavia, devem vir munidos de significação. Isso foi ratificado em "Muito mais que "treinamento", é necessário que os professores desenvolvam a habilidade de beneficiarem-se da presença dos computadores e de levarem esse benefício para seus alunos." (PAPERT, 2008, p. 79). A não percepção de benefícios é uma das razões dos professores refutarem o curso ministrado. Confirmação apresentada também por Al-Senaidi e Poirot (2009) em que essas percepções, descrenças nos benefícios, tornam-se barreiras ao uso da tecnologia envolvida.

No tocante a Influência Social, algumas inferências foram feitas tanto nos dados obtidos quantitativamente quanto nos qualitativos. Ambos nos levam a apresentar um professor que manifesta um posicionamento crítico e autônomo em relação a influências das mídias e em particular, ao Tablet Educacional, desprendido de opiniões alheias. No entanto, ao tratar do tablet como forma de aproximação entre amigos e familiares, nossa população fonte não tem clareza dessa influência.

Quanto à influência em seu ambiente de trabalho, os dados mostraram um professor dúbio em suas ideias, mas que ao longo da pesquisa o seu posicionamento confirma que a opinião concerne a do seu aluno, ou seja, ele está preocupado com a essa opinião. Uma das possíveis explicações para essa influência estudantil ao professor é a busca pela linguagem digital dos jovens alunos que nasceram em uma época tecnológica e vivem ligados ou mesmo conectado à ela (PRENSKY,2001). Nossos nativos digitais lidam com as informações e o conhecimento diferentemente dos imigrantes digitais. E a escola (neste caso, o professor) atenta às mudanças procura se aproximar dessa realidade em prol de um ensino significativo (PAPERT, 2008), avanço para uma sabedoria digital, na qual o indivíduo a partir da tecnologia digital e suas ferramentas, conhece suas habilidades e no uso dessa tecnologia, ele aprimora a sua capacidade cognitiva (PRENSKY, 2009).

E, para essa mesma população, no convívio de trabalho, o uso dessa ferramenta diminui a distância entre gerações, pode estreitar os laços com seus alunos, bem como, com os pais/ responsáveis. Esse último resultado: aproximação de gerações por meio da tecnologia corrobora com outros estudos realizados, como o de Oliveira (ALMEIDA, (Org.), 2011) em que afirma que o domínio da tecnologia, no caso o laptop do Programa UCA, dispõe de tempo, preparação e dedicação para ampliar os horizontes pedagógicos e nas relações com os seus alunos.

Quanto ao Constructo Condições Facilitadoras, que possui influência direta no comportamento de uso da ferramenta tecnológica, a abordagem quantitativa trouxe-nos um dado importante ao comparar o período da versão preliminar à versão final do questionário, 
épocas distintas e resultados distintos que evidenciam um chamado do professor à formação quanto o ambiente envolto neste período. Essa Condição Facilitadora foi analisada em todas as fases. E conforme mencionado na versão preliminar, as três categorias: obrigação, curiosidade e aprimoramento, foram evidenciadas também na etapa final. Mas a preocupação dos pesquisados, nesse momento, foi ressaltar a importância para a ação governamental e salientar a continuidade com mais organização. Há ainda a inquietação de serem ouvidos primeiramente, para que a formação possa atingir os anseios dessa clientela.

A partir das suas experiências tecnológicas o professor comparou o tablet com outros recursos tecnológicos: tablets, computador pessoal, notebook, celulares. E percebeu um recurso aquém das suas necessidades. Mas para aqueles que não possuíam familiaridade com nenhum recurso tecnológico específico, a iniciativa foi válida. Essa fase também foi vivida por Papert (2008) em MIT com os computadores: "Estávamos descobrindo o que poderia ser feito com um computador, e qualquer coisa interessante seria válida.” (PAPERT, 2008, p. 44) e que em seguida produziu vários conhecimentos e experiências.

Dando continuidade às Condições Facilitadoras, as condições ideais e as reais, proferidas por nossos entrevistados, para o uso efetivo do Tablet Educacional no ambiente escolar foram representadas em forma de quadro. Aspectos importantes foram mencionados: internet, velocidade do tablet, material didático-pedagógico, disponibilidade do recurso ao aluno e inclusive àqueles relacionados à infraestrutura, sem a qual inviabilizada o uso do recurso tecnológico. Uma pesquisa (GÖĞÜŞ et al., 2012) sugere o acréscimo de mais uma variável para o modelo de aceitação por ter se mostrado relevante: a disponibilidade de infraestrutura. Esse resultado é dirigido ao nosso contexto devido à menção a ela como condição primária ao projeto. Outro resultado em torno das facilidades foi o de qualificar a formação como um fator positivo para o uso do recurso tecnológico, e que a mesma deve continuar com atividades pontuais, principalmente para os imigrantes digitais iniciantes. Essa conclusão corrobora com resultados encontrados na pesquisa sobre a aceitabilidade dos professores no Projeto Um Computador por Aluno (SILVA et al, 2011).

Outra condição facilitadora aludida pelos entrevistados versa sobre a figura de um monitor ou técnico para auxiliá-los na condução das aulas com o equipamento.

Sendo assim, as Condições Facilitadoras notam-se, segundo relato dos entrevistados e percentuais apresentados, como um fator determinante para a receptividade do recurso tecnológico tablet e, consequentemente, influencia de forma direta o uso. No entanto, em nossa pesquisa somente a intenção de uso dessa tecnologia foi evidenciada. Ocorrência também ratificada pelos professores alemães (LFENTHALER, SCHWEINBEN, 2013). 
O tratamento agora recai sobre a Intenção de Uso do Tablet pelo pesquisado. Categoricamente, todos os entrevistados se predispuseram a utilizá-lo, e sentem-se seguros e preparados. Porém, essa ação está condicionada às Condições Facilitadoras, ratificando a conclusão feita no parágrafo anterior e corroborando com os achados da pesquisa sobre o laptop no estado dos Texas-USA em que os professores destacam a formação profissional como fator que aumenta as chances de uso ao fazer pedagógico (INAN, LOWTHER, 2010).

Por fim, constata-se que o modelo UTAUT foi válido neste estudo de caso reforçando a presença dos quatro constructos determinantes. No entanto, uma limitação ao estudo diz respeito à ausência de comprovações estatísticas entre esses constructos e os fatores moderadores. A correlação entre eles determina a Intenção de Uso, mas não foi possível devido à insuficiência de números de dados coletados. O período destinado a coleta de dados da fase preliminar é considerado corrido no âmbito escolar devido a provas finais, conselhos de classe e fechamento do ano letivo, além da aproximação do recesso escolar, festividades de final de ano e início das férias coletivas da categoria. Esses são alguns argumentos para o índice pequeno de retorno da primeira coleta.

Outra limitação consiste na falta de uma análise longitudinal sobre o fenômeno a fim de avaliar o constructo Comportamento de Uso quanto ao Tablet Educacional.

Segundo Bardin (2009) os resultados e as análises expostos não são inelutáveis, mas ilustram mesmo que parcialmente as conjecturas do estudo. A presente pesquisa pauta-se nesta declaração e exibe a realidade que muitos não veem, ou ignoram. Esse caminho está aberto a futuras pesquisas que podem aperfeiçoar e avançar nos estudos e na aplicação do modelo UTAUT na íntegra. 


\section{CONSIDERAÇÕES FINAIS}

Neste momento, delineio considerações sobre os resultados alcançados nesta dissertação. A partir da teoria e da metodologia escolhidas, retomo as cinco questões norteadoras que motivaram a pesquisa.

A primeira questão: Qual o nível de aceitação do professor quanto ao recurso tecnológico tablet no contexto educacional? As atitudes dos professores pesquisados demonstram autonomia na decisão de utilizá-lo ou não em sala de aula, postura contrária a Cultura de Massa apresentada por Eco (1970). No entanto, a resistência em utilizar o tablet como sua primeira opção, dentre outras tecnologias disponíveis na escola, é impetuosa.

Esse nível de aceitação baixo está relacionado à incerteza do professor quanto à relevância do Tablet Educacional em seu local de trabalho. Reflexo da falta de resultados nas práticas pedagógicas vivenciadas com as diversas tecnologias. Ponto levantado e fomentado na segunda questão norteadora.

A segunda questão norteadora: Quais as expectativas dos professores em relação ao Tablet Educacional ao seu uso na prática pedagógica? O docente associa o tablet a mais um problema no âmbito escolar, dentre tantos oriundos das tecnologias. Um exemplo referese à incompatibilidade do Tablet Educacional com o diário eletrônico. Nota-se que o professor quer adequar o recurso tecnológico em estudo, e quaisquer outros, às suas práticas tradicionais e corriqueiras, muitas até consideradas ultrapassadas, mas que fazem parte da realidade escolar. Essa constatação pode explicar a frustação e a expectativa negativa do professor ao recurso tecnológico em estudo. Mas há também o professor que admite o uso do tablet na sua prática pedagógica de forma transformadora, voltado para alcançar o seu aluno em uma aproximação de gerações, através de vídeos, animações, simulações, acervos advindos da Internet. Vislumbra-lhe, também, a partilha de responsabilidades com os estudantes e parcerias em prol de novas habilidades necessárias por meio das tecnologias, ou seja, na busca da sabedoria digital mencionada por Prensky (2012). A esses que procuram novas formas de ensino, com as tecnologias, enfrentam demanda de tempo e esforço para aprender, já que, à vista da nossa população fonte, a organização do curso de formação do projeto não atendeu às suas necessidades.

A terceira questão volta-se para o curso de formação oferecido, uma das condições facilitadoras, determinantes para o comportamento de uso da tecnologia: Quais as expectativas dos professores em relação ao curso de formação oferecido pela 
Instituição? De modo geral, é possível perceber nesta pesquisa que as expectativas do professor são favoráveis a formações continuadas em relação ao Tablet Educacional. No desejo de estar atualizado ou na ânsia de vislumbrar benefícios em suas aulas práticas, esse professor afirma a necessidade de formação continuada, seja em forma de oficinas específicas, seja por cursos mais curtos, mas pautados nas aspirações dessa clientela.

Importa mencionar ainda que, ao indagar sobre a predisposição do entrevistado ao curso de formação, mesmo sem a sua obrigatoriedade, 57\% manifestaram-se a favor em contraposição a 28\%. O interesse em aprender mais, em dominar a ferramenta, em procurar benefícios e a curiosidade em relação ao recurso tecnológico são alguns dos motivos relevantes para a busca dessa formação. Uma formação continuada pode ampliar as habilidades e competências do século XXI (DEMO, 2010) alargando os níveis de familiaridade do professor e bem provavelmente haja mudanças na prática pedagógica com o uso do recurso tecnológico.

No entanto, ao investigar o nível de aceitação ao Tablet Educacional pelo ângulo da formação prevista e ofertada aos professores, os dados quantitativos coletados e repassados pela Eape/GDF concernente ao recebimento dos tablets e à comparação dos números de professores envolvidos no projeto como os concluintes com êxito no curso de formação promovido apresentam índices que contrariam a predisposição mencionada. Do montante inicial de 3.050 professores que receberam o equipamento, há apenas 90 professores concluintes do curso em todo o DF, perfazendo menos de $3 \%$ do universo. Os números revelam que os professores estão de acordo com o projeto, porém não concordaram com a formatação e encaminhamentos do curso para o Tablet Educacional, evidência de pouco ou quase nenhuma receptividade a essa ação governamental.

Mas de modo geral, é possível perceber que as expectativas do professor são favoráveis a formações continuadas em relação ao Tablet Educacional. No desejo de estar atualizado ou na ânsia de vislumbrar benefícios em suas aulas práticas, esse professor afirma a necessidade de formação continuada, seja em forma de oficinas específicas, seja por cursos mais curtos, mas pautados em suas aspirações.

Importa mencionar ainda que, ao indagar sobre a predisposição do entrevistado a um curso de formação, mesmo sem a sua obrigatoriedade, 57\% manifestaram-se a favor em contraposição a $28 \%$. O interesse em aprender mais, na curiosidade em relação ao recurso tecnológico, em dominar a ferramenta, em procurar benefícios são alguns dos motivos relevantes para a busca dessa formação. Uma formação continuada pode ampliar as habilidades e competências do século XXI (DEMO, 2010) alargando os níveis de 
familiaridade do professor e bem provavelmente haja mudanças na prática pedagógica com o uso do recurso tecnológico.

Por fim, a quarta e última questão: Como o professor avalia a necessidade dessa tecnologia - Tablet - no âmbito escolar? Avaliar essa necessidade do professor com o tablet envolve desvendar seus interesses acerca dessa tecnologia no contexto escolar. E seu interesse maior é o aluno: aproximar-se dele por meio do recurso além do espaço escolar, propor aulas mais criativas e interessantes para ele, aproveitar esse fascínio do aluno pelas TDIC e envolvê-lo em suas aulas e nos conhecimentos espalhados pela Internet. No entanto, essa necessidade enfraquece a cada empecilho de uso da tecnologia, desde questões de infraestrutura, tais como: configurações do tablet, inserção de programas educativos, internet de ótima qualidade; à formação continuada para auxílio no manuseio do recurso tecnológico na preparação das aulas.

Vale ressaltar que houve uma limitação parcial desse estudo à proposta inicial de aplicabilidade da Teoria Unificada de Aceitação e Uso da Tecnologia - UTAUT - para o nosso contexto. A análise da aceitação dos professores do DF ao Tablet Educacional e sua receptividade não foi plenamente concluída, devido ao tamanho da amostra se revelar insuficiente. Esse fato foi evidenciado na aplicação do software SPSS Amos aos dados coletados por meio do questionário, em que algumas variáveis que estavam previstas para serem testadas não puderam ser analisadas nesse programa, inviabilizando algumas correlações entre variáveis. Porém, essas correlações foram exploradas e confirmaram o diagnóstico previsível. Esse índice pode estar associado à dificuldade do nosso pesquisado em revelar suas percepções e crenças acerca da temática do estudo, expondo seus medos e receios a respeito das novas mídias no seu ambiente de trabalho. Outro fator pode relacionar-se com a rejeição à política de governo, que muitas vezes, são impostas, sem ater-se às necessidades do professor.

Por conseguinte, futuros trabalhos devem precaver-se ao número de integrantes do estudo e em novas formas de convites, de forma individual e direta, no seu ambiente de trabalho, para efetiva participação nas pesquisas, suprimindo a limitação citada. E ainda, adequar a disponibilidade dos instrumentos de acordo com o calendário escolar, evitando momentos com mais atividades pedagógicas.

O Projeto Educação Digital insere o tablet no mundo escolar, mais especificamente, nas mãos do professor. Essa ação é mais uma experiência que se apresenta como uma realidade emergente no campo da tecnologia educacional; um futuro inevitável nesta sociedade. Todavia, neste estudo, fica explícito a aceitação do Tablet Educacional por parte 
da população fonte, professores do ensino médio de Ceilândia- DF, a essa nova tecnologia inserida no ambiente escolar. No entanto, para alcançar um nível maior de aceitação à esse recurso tecnológico, algumas mudanças no processo da inserção devem ser tomadas. Percebese que esse professor quer ser ouvido nas suas necessidades e que o presente projeto não atende aos anseios dessa clientela. Por isso, a receptividade inexpressiva ao Tablet Educacional é explícita. A compreensão dos níveis de aceitação, a receptividade, a percepção do professor em relação às tecnologias pode, não somente, auxiliá-lo, como também os demais profissionais da educação, na prévia identificação dos problemas, bem como, nas possíveis soluções para a implementação, do tablet ou quaisquer que sejam as tecnologias.

Convém também salientar que a apropriação, o engajamento, a aceitação ou a rejeição, o sucesso ou o fracasso desses programas está nas mãos do mentor/ articulador do ensinoaprendizagem: o professor. No entanto, o professor, como muitos atores da sociedade, encontra-se também na busca da sua identidade, muitas vezes advinda das experiências e conhecimentos adquiridos. E "a busca da identidade é tão poderosa quanto a transformação econômica e tecnológica no registro da história." (CASTELLS, 2011, p. 42). Por isso pesquisas acerca dessa temática sejam necessárias e importantes para termos uma compreensão maior das ações, reações dos comportamentos envoltos na adoção de tecnologia e comportamentos de uso no contexto escolar.

Este estudo de caso ajudou a analisar as percepções dos professores a respeito ao Tablet Educacional e ainda a sua receptividade como ferramenta pedagógica, nosso objetivo central desde o início. Além disso, esta pesquisa tentou aproximar-se da realidade do professor, dos seus anseios e dificuldades para conhecer a posição desse sujeito ao Tablet Educacional, como também da transformação tecnológica em relação às questões de base levantadas.

Outras possíveis contribuições podem ser atribuídas:

$\checkmark$ Ao estudo, à divulgação e aplicação da Teoria UTAUT, pouco explorada no Brasil.

$\checkmark$ À validação estatística dos 4 fatores determinantes da Teoria UTAUT: Expectativa de Desempenho/Performance, Expectativa de Esforço, Influência Social e Condições Facilitadoras. São evidências da adequação às variáveis desse estudo a proposta original, ou seja, a teoria é apropriada também ao contexto educacional e a um recurso tecnológico específico.

$\checkmark$ À investigação de uma situação atual vivida por nossos professores com a inserção de uma nova tecnologia, o Tablet Educacional. 
A partir das análises e das discussões levantadas acerca das percepções dos professores, na qual expectativas, julgamentos e experiências foram apreendidas, novos insights, novas concepções, novas indagações abrem espaços para novas pesquisas. Lanço o convite à busca de novos caminhos e novas descobertas. 


\section{REFERÊNCIAS}

ABBAGNANO, NICOLA. Dicionário de Filosofia. $5^{\text {a }}$ edição revista e ampliada. São Paulo: Martins Fontes, 2007.

ABU-AL-AISH, Ahmad; LOVE, Steve. Factors Influencing Student's Acceptance of MLearning: An Investigation in Higher Education. IRR ODL- The Internacional Review of Research in Open and Distance Learning. Athabasca University, Canadá. v. 04, n.05, p. 82107, dez. 2013.

ALMEIDA, M. E. B.; PRADO, M. E. B. B. (Org.). O Computador Portátil na Escola: Mudanças e desafios nos processos de ensino e aprendizagem. São Paulo: Avercamp, 2011.112p.

AL-SENAIDI, D. ;L. L. ; POIROT, J. Barriers to adopting technology for teaching and learning in Oman. Science Direct Elsevier. Computers in Human Behavior, Amsterdã , v. 53, n. 03, p. 575- 590, nov. 2009. Disponível em:

<http://www.sciencedirect.com/science/article/pii/S0360131509000827>. Acesso em: 01 out. 2013.

BARDIN, Laurence. Análise de conteúdo. Lisboa: Edições 70, LDA. Março de 2009.

BERGSON, Henri. œuvres. Édition du Centenaire, Textes annotés par André Robinet, Introduction de Henri Gouhier. Paris: PUF, 1970.

BERNARDO, J.C.O. Dispositivos móveis digitais na incrementação do processo de ensino e aprendizagem: mobile learning no rompimento de paradigmas. Revista EDaPECI, São Cristovão (SE), v.13,n.1,p.141-157, jan/abr. 2013.

BOBSIN, Debora. VISENTINI, Monize Sâmara. Em Busca do Estado da Arte do UTAUT: Ampliando as Considerações Sobre o Uso da Tecnologia. RAI - Revista de Administração e Inovação, São Paulo, v. 6, n. 2, p. 99-118, 2009. Disponível em:<http://www.revistarai.org/rai/article/view/275>. Acesso em: 25 set. 2013.

BRASIL. Secretaria de Educação Fundamental. Parâmetros curriculares nacionais: língua portuguesa/ Ministério da Educação 3a . Ed. - Brasília: MEC/SEF, 2001.

BRASIL. Ministério da Educação e Cultura. 2 anos da TV Escola - Seminário Internacional, 1998. Série de Estudos - Educação a Distância. Brasília: MEC, 1999. 112p. Disponível em < http://www.dominiopublico.gov.br/download/texto/me002693.pdf>. Acesso em 05 fev.2014.

BRASIL. Ministério da Educação e do Desporto. Portaria n522, de 9 de abril de 1997. Disponível em <http://www.dominiopublico.gov.br/download/texto/me001167.pdf>. Acesso em 03 fev. 2014. 
BRASIL. Ministério da Educação e do Desporto. Programa Nacional de Tecnologia Educacional. Disponível em: <http://www.fnde.gov.br/programas/programa-nacional-detecnologia-educacional-proinfo/proinfo-perguntas-frequentes>. Acesso em 03 fev. 2014.

BRASIL. Ministério da Educação. Apresentação do Proinfo. Disponível em: <http://portal.mec.gov.br/index.php?Itemid=462>. Acesso em: 03 fev. 2014.

BRASIL. Ministério da Educação. Introdução à Educação Digital - Guia do Formador. Brasília: Ministério da Educação, Secretaria de Educação à Distância; 2008. 1a edição. 113p.

BRASIL. Ministério da Educação. Site institucional do PROUCA. Disponível em <http://www.uca.gov.br/institucional/index.jsp>. Acesso em: 10 fev. 2014.

BRASIL. Ministério da Educação. Cartilhas Projeto UCA. Rio de Janeiro, 2010. Disponível em <http://www.uca.gov.br/institucional/downloads/cartilhaUCARNP.pdf>. Acesso em: 11 fev. 2014.

BRASIL. Presidência da República. Decreto nº 6.300, de 12 de dezembro de 2007. Disponível em:<http://www.planalto.gov.br/ccivil_03/_Ato20072010/2007/Decreto/D6300.htm>. Acesso em: 17 fev. 2014.

BRASIL. Ministério da Educação e do Desporto/SEED. Programa Nacional de Informática - PROINFO: Diretrizes. Brasília, 1997. 23p. Disponível em: <http://www.gestaoescolar.diaadia.pr.gov.br/arquivos/File/pdf/proinfo_diretrizes1.pdf>. Acesso em: 17 fev. 2014.

BRASIL. Ministério da Educação. Proinfo Integrado. Disponível em: <http://portal.mec.gov.br/index.php?option=com_content\&view=article\&id=13156:proinfointegrado\&catid=271:seed $>$. Acesso em: 19 fev. 2014.

BRASIL. Ministério da Educação- Fundo Nacional de Desenvolvimento da Educação. Tablet Educacional. Disponível em: < http://www.fnde.gov.br/tableteducacional/inicio >. Acesso em: 01 ago. 2014.

BROWN, S. A.; VENKATESH, V.; GOYA, S. L. Expectation Confirmation in Technology Use. Information Systems Research, v. 23, n. 2, p. 474-487, Junho 2012. Disponível em: <http://isr.journal.informs.org/content/23/2/474.full.pdf+html>. Acesso em: 30 set. 2013.

BUSCAPÉ - Comparação de preços, produtos e serviços. Tablet Sansung Galaxy. Disponível em: <http://www.buscape.com.br/samsung-galaxy-tab-3-8-0-sm-t311-3g16.html\#precos >. Acesso em: 01 ago. 2014.

CARNEIRO, V. L. Q. Tecnologia audiovisuais TV e vídeo na Escola.Capítulo 3, p. 102 105, 2005. Disponível em: <http://pt.slideshare.net/aurelyano/capitulo-3-tecnologiaaudiovisuais-tv-e-video-na-escola>. Acesso em 17 fev. 2014 
CARNEIRO, V. L. Q. A TV como objeto de estudo na formação e prática de educadores: prazer e crítica.Cadernos de Educação/ FaE/UFPel , Pelotas V.28, p. 197 - 212, janeiro/jun. 2007.

CASTELLS, M. A Sociedade em Rede. Tradução de Roneide Venancio Majer. $6^{\text {a }}$ edição.São Paulo: Editora São Paulo: Paz e Terra Ltda, 2011. Volume I.

CYSNEIROS, P.G. Artigo: La Asimilación de la informática por parte de la escuela.Tradução:Olga Mariño D. Informática Educativa, Proyecto SIIE,Colômbia, v.9, n. 1, p.45-55,1996. Disponível em: 〈http://ufpe.academia.edu/PauloGilenoCysneiros〉. Acesso em 11 fev. 2014.

CRESWELL, John W. Projeto de pesquisa: métodos qualitativo, quantitativo e misto. Tradução: Magda Lopes; Consultoria, supervisão e revisão técnica desta edição: Dirceu da Silva. -3. Ed. - Porto Alegre: Artmed, 2010.

DAVIS, Fred D. Perceived Usefulness, Perceived Ease of Use, and User Acceptance of Information Tecnology. MIS Quarterly, v. 13, n. 3, p. 318-340, 1989.

DEMO, Pedro. Artigo: Habilidades do Século XXI. B. Téc. Senac: a R. Educ. Prof., Rio de Janeiro, v. 34, n.2, maio/ago. 2008.

Conhecimento e aprendizagem na nova mídia. Brasília: Editora Plano, 2001.

ECO, U. Apocalípticos e Integrados. São Paulo: Perspectiva,1970.

ESCOLHA FÁCIL - Tablet - melhor custo X Benefício. Disponível em: < http://escolhafacil.net/melhor-tablet-custo-beneficio/>. Acesso em: 01 ago. 2014.

FERKISS, V.C. O homem tecnológico- Mito e Realidade. Rio de Janeiro: Zahar Editores, 1976.

FREIRE, Paulo. Pedagogia da autonomia: saberes necessários à prática educativa. São Paulo: Paz e Terra, 1997.

FREIRE, Wendel (Org.). Tecnologia e Educação - As mídias na prática docente. Editora Wak, 2011.

FISHBEIN, Martin; AJZEN, Icek. Belief, atitude, intention and behavior: An introduction to theory and research. Addison-Wesley. Reading.1975. Disponível em < http://people.umass.edu/aizen/f\&a1975.html>. Acesso em 10 fev. 2014.

FUGIMOTO, S.M.A; ALTOÉ, A. Perspectivas dos Professores quanto à Utilização do Computador no Desenvolvimento da Prática Pedagógica. In: X Congresso Nacional de Educação- EDUCERE, 2011, Curitiba. Anais.Curitiba, PUC Paraná, 2011, p. 5596-5610 
GEE, J. P. Situated language and learning: a critique of traditional schooling. New York :Routledge, 2004.

GIL, Antonio Carlos. Métodos e técnicas de pesquisa social.- 6. ed. - 3. reimpr. - São Paulo: Atlas, 2010.

GUERRA, Isabel Carvalho. Pesquisa Qualitativa e Análise de Conteúdo- Sentidos e Formas de Uso. Portugal: Princípia Editora, 2006.

INAN. F.A., LOWTHER, D. L. Laptops in the K-12 classrooms: Exploring factors impacting instructional use. ScienceDirect Elsevier. Computers in Human Behavior, Amsterdã, Volume 55 n. 03, p. 937- 944, nov. 2010. Disponível em:

<http://www.sciencedirect.com/science/article/pii/S0360131510001119>. Acesso em: 22 out. 2013.

JENKINS, Henry. Cultura da Convergência. Tradução Susana Alexandria. - 2.ed.- São Paulo: Aleph, 2009.

JORGE, A. M. Introdução à Percepção: entre os sentidos e o conhecimento. 1 ed. São Paulo: Paulus, 2011.125 p.

KANT, Immanuel. Crítica da razão Pura.Tradução Manuela Pinto dos Santos e Alexandre Fradique Morujão - 5. Ed.- Lisboa: Edição da Fundação Calouste Gulbenkian, 2001.

KOPCHA, Theodore J. Teachers' perceptions of the barriers to technology integration and practices with technology under situated professional development. Science Direct Elsevier. Computers in Human Behavior, Amsterdã ,Volume 59, n. 04, p. 1109- 1121, dezembro. 2012. Disponível em:

<http://www.sciencedirect.com/science/article/pii/S0360131512001352>. Acesso em:13 ago. 2014.

LAVILLE,C; DIONNE, J. A Construção do Saber- Manual de metodologia da pesquisa em ciências humanas.Editora UFMG. Porto Alegre: Artmed, 1999.340 p.

LEMOS, André. Cibercultura - Tecnologia e vida social na cultura contemporânea. $5^{\text {a }}$ edição. Porto Alegre:, Editora Sulina, 201, p.296.

LÉVY, Pierre (1956). Cibercultura. Tradução de Carlos Irineu Costa.São Paulo: Editora 34 Ltda, 2010. 3 ed., 1 reimpr., 2011.272p.

LFENTHALER. Dirk, SCHWEINBEN, Volker. The acceptance of Tablet-PCs in classroom instruction: The teachers' perspectives. Science Direct Elsevier. Computers in Human Behavior, Amsterdã ,Volume 29, n. 03, p. 525- 534, maio. 2013. Disponível em: <http://www.sciencedirect.com/science/article/pii/S0747563212003093\#b0020>. Acesso em: 25 set. 2013.

LOCKE, John. Ensaio Acerca do Entendimento Humano, em Os Pensadores. São Paulo: Abril Cultural, 1978. 
MARTÍN-BARBERO, Jesús. Nuevos regímenes de visualidade y descentramientos culturales. Bogotá (Colômbia), 1998. Cópia reprográfica

MOLIN, S. L. RAABE, A. Novas Tecnologias na Educação: transformações da prática pedagógica no discurso do professor. Acta Scientiarum Education, Maringá, v.34, n.2, p.249-259, July-Dec., 2012.

MORAN, J. M. Desafios da Televisão e do vídeo à escola. In: ALMEIDA, M. E.B;

MORAN, J. M. Integração das Tecnologias na Educação. Salto para o Futuro. Brasília: MEC/SEED, 2005. p.96-100.

MURRAY, Janet H. Hamlet no holodeck: o futuro da narrativa no ciberespaço. Tradução: Elissa Khour Daher, Marcelo Fernandes Cuzziol. - São Paulo: Itaú Cultural: Unesp, 2003.

NEVES, C. M. C. Próxima atração: a TV que vem aí. In: ALMEIDA, M. E.B; MORAN, J. M. Integração das Tecnologias na Educação. Salto para o Futuro. Brasília: MEC/SEED, 2005. p.88-91.

GÖĞÜŞ, A.; NISTOR,N.; LERCHE, T.; Educational Technology Acceptance Across Cultures: A Validation Of The Unified Theory Of Acceptance And Use Of Technology In The Context Of Turkish National Culture. TOJET: The Turkish Online Journal of Educational Technology, vol. 11, nº 4, Out. 2012, p.394-408.

OLIVEIRA, M.; CAMACHO, J.; GISBERT.M. Explorando la percepción de estudiantes y profesor sobre el libro de texto electrónico em educación primaria. Comunicar, Huelva, vol.21, nº42, jan. 2014, p.87-95. Disponível em <http://educa.fcc.org.br/scielo.php?script=sci_arttext\&pid=S1988$32932014000100010 \& \operatorname{lng}=$ pt\&nrm=iso $>$. Acesso em 13 out. 2014.

PAPERT, Seymour. A máquina das Crianças: repensando a escolar na era da informática. Tradução: Sandra Costa. - ed. Ver.- Porto Alegre: Armed, 2008.

PRENSKY, Marc. Digital game-based learning. McGraw-Hill, New York, 2001; Id. Don't bother me mom: I'm learning! Minnesota: Paragon House, 2006.

Digital Natives, Digital Immigrants. MCB University Press, vol.9, nº5, Oct. 2001. Disponível em: <http://www.marcprensky.com/writing/prensky\%20$\% 20$ digital\%20natives, \%20digital\%20immigrants\%20-\%20part1.pdf $>$. Acesso em: 16 mai. 2012. em: 22 jan. 2014.

Digital Natives. Disponível em: <http://marcprensky.com/digital-native〉. Acesso

Digital Wisdom (H. Sapiens Digital) - Moving beyound Natives and Immigrants. Innovate, fev./mar, 2009. Disponível em: <http://www.wisdompage.com/Prensky01.html>. Acesso em: 05 fev. 2014. 
. Nativo Digital, Imigrante Digital ou Sábio Digital? Disponível em < http://www.playground-inovacao.com.br/teste-2/>. Acesso em: $10 \mathrm{de} \mathrm{fev.} 2015$

QSR International. Software Nvivo. Disponível em: < http://www.qsrinternational.com/otherlanguages_portuguese.aspx >. Acesso em: 25 nov. 2014

SANTOS, G.L.; BRAGA, C.B. Tablets, laptops, computadores e crianças pequenas: novas linguagens, velhas situações na educação infantil. Brasília: Liber Livros, 2012.p.96.

SILVA, P.; PIMENTEL, V.; SOARES, J. Uso do computador no sertão da Paraíba: estudos sobre a adoção tecnológica pelos professores das cidades de Patos e Brejo do Cruz. Revista de Tecnologias e Mídias na Educação- RETEME, João Pessoa, v. 1, n. 01, p. 107- 120, jan./jun. 2011. Disponível em:

<http://www.reteme.org.br/index.php/reteme/article/view/23>. Acesso em: 04 out. 2013.

IBM. SPSS Amos. Disponível em: < http://www-03.ibm.com/software/products/pt/spss-amos >. Acesso em: 14 jan. 2015

TECHTUDO. 5 Melhores Tablets do Mercado. Disponível em:

<http://www.techtudo.com.br/noticias/noticia/2013/11/conheca-os-cinco-melhores-tablets-domercado-com-entrada-para-chip-sim.html >. Acesso em: 01 ago. 2014.

UNESCO, Organização das Nações Unidas para a Educação, a Ciência e a Cultura. 2008. Título original: ICT competency standards for teachers: competency standards modules. Paris: UNESCO, 2008. Padrões de Competência em TIC para professores. Trad. sob a direção Cláudia Bentes David. 2009. Disponível em: < http://unesdoc.unesco.org/images/0015/001562/156209por.pdf>. Acesso em: 10 out. 2014.

VALENTE, José A.; MARTINS, Maria C. O Programa Um Computador por Aluno e a Formação de Professores das Escolas Vinculadas à UNICAMP. Revista Geminis, ano 2, n.1. p.116-136, 2011. Disponível em:

<http://www.revistageminis.ufscar.br/index.php/geminis/article/view/43>. Acesso em: 3 fev. 2014.

VENKATESH, V.; BALA, H. (2008).Tecnologia Acceptance Model 3 e uma agenda de investigação sobre as intervenções. Ciências da Decisão, 39 (2): 273-315, 2008.

VENKATESH, V.; DAVIS, Fred. A theoretical extension of the technology acceptance model: four longitudinal field studies. Management Science, v. 46, n. 2, p.186-204, 2000.

VENKATESH, V.; MORRIS, Michael G.; DAVIS, Gordon B.; DAVIS, Fred D. User Acceptance of Information Technology: Toward a Unified View. MIS Quarterly. Vol. 27, n. 3, p. 425-478, set. 2003. Disponível em <

http://nwresearch.wikispaces.com/file/view/Venkatesh+User+Acceptance+of+Information+T echnology+2003.pdf > . Acesso em: 18 fev. 2014. 


\section{APÊNDICE A - E-mail convite}

\section{Convite ao Questionário}

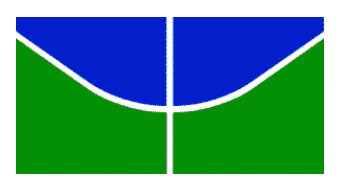

Olá caro (a) professor (a),

Convido você a participar da minha pesquisa de mestrado: PERCEPÇÕES DOS PROFESSORES DA REDE PÚBLICA SOBRE O TABLET EDUCACIONAL, da Universidade de Brasília que conforme o título, visa analisar as percepções e a receptividade do professor ao Tablet Educacional.

Para tal, reserve um tempinho para responder ao questionário que faz parte da pesquisa. Sua participação é valiosa!!!

Lembrando que a qualquer momento você pode cancelar a pesquisa. Sua identificação é confidencial e sigilosa.

Então, vamos ao questionário?!

Clique neste

link: https://docs.google.com/forms/d/1DXbP0k2_nkiopxOB82chj_m9yERDLVjT16mkfCB1 Oss/viewform

Desde já, MUITO OBRIGADA!

Adriana Moura

Mestranda da Faculdade de Educação - UNB

\section{Convite à Entrevista Semiestruturada}

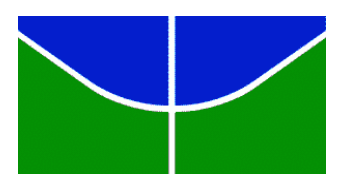

Olá caro (a) professor (a),

Primeiramente gostaria de agradecer a sua VALIOSA participação na minha primeira etapa da pesquisa de mestrado: PERCEPÇÕES DOS PROFESSORES DA REDE PÚBLICA SOBRE O TABLET EDUCACIONAL, da Universidade de Brasília, ao responder o questionário enviado por e-mail. Muitíssimo obrigada! 
Agora estamos na segunda etapa da pesquisa: AS ENTREVISTAS, e venho novamente convidá-lo a participar! :)

Essa sua NOVA PARTICIPAÇÃO é fundamental para aprofundar o tema em questão e complementar itens do primeiro instrumento, o questionário.

Caso você aceite o convite, por favor, confirme seu interesse me respondendo esse e-mail com sua sugestão de dia da semana e horário mais adequado para esse encontro. Desta forma, manterei contato, para marcarmos a ida à sua escola.

Desde já, MUITO OBRIGADA PELA ATENÇÃO!

Adriana Moura

Mestranda de Educação em Mídias na UNB 
APÊNDICE B - Quadro Comparativo dos itens da Teoria UTAUT com os da nossa Pesquisa

Quadro com os quatro constructos determinantes originais da teoria UTAUT e as adaptações feitas para o contexto desta pesquisa e presentes no questionário:

\begin{tabular}{|c|c|}
\hline \multicolumn{2}{|c|}{ Constructo Expectativa de Performance / Desempenho } \\
\hline Itens originais da UTAUT & Itens adaptados a essa pesquisa: \\
\hline $\begin{array}{l}\text { U6: I would find the system useful in my } \\
\text { job. }\end{array}$ & $\begin{array}{l}\text { ED1: Eu acho que o tablet é útil em meu } \\
\text { trabalho. }\end{array}$ \\
\hline $\begin{array}{l}\text { RA1: Using the system enables me to } \\
\text { accomplish tasks more quickly. }\end{array}$ & $\begin{array}{l}\text { ED2: O uso do tablet me permite poupar } \\
\text { tempo em minhas tarefas. }\end{array}$ \\
\hline $\begin{array}{l}\text { RA5: Using the system increases my } \\
\text { productivity. }\end{array}$ & $\begin{array}{l}\text { ED3: Utilizando o tablet, tenho mais chances } \\
\text { de inovar o processo de ensino-aprendizagem } \\
\text { em minhas aulas. }\end{array}$ \\
\hline $\begin{array}{l}\text { OE7: If } \mathrm{i} \text { use the system, I will increase my } \\
\text { chances of getting a raise. }\end{array}$ & $\begin{array}{l}\text { ED4: O uso do tablet melhora meu } \\
\text { desempenho no trabalho. }\end{array}$ \\
\hline \multicolumn{2}{|c|}{ Constructo Expectativa de Esforço } \\
\hline Itens originais da UTAUT & Itens adaptados a essa pesquisa: \\
\hline $\begin{array}{l}\text { EOU3: My interaction with the system } \\
\text { would be clear and understandable. }\end{array}$ & $\begin{array}{l}\text { EE1: A utilização dos aplicativos no Tablet é } \\
\text { simples e fácil de entender. }\end{array}$ \\
\hline $\begin{array}{l}\text { EOU5: It would be easy for me to become } \\
\text { skillful at using the system. }\end{array}$ & $\begin{array}{l}\text { EE2: É fácil para mim me tornar um usuário } \\
\text { habilidoso do Tablet. }\end{array}$ \\
\hline EOU6: I would find the system easy to use. & $\begin{array}{l}\text { EE4: Eu acho que o Tablet é fácil de usar em } \\
\text { comparação com o computador pessoal (PC). }\end{array}$ \\
\hline $\begin{array}{l}\text { EU4: Learning to operate the system is } \\
\text { easy for me. }\end{array}$ & $\begin{array}{l}\text { EE3: Aprender a utilizar o Tablet é fácil para } \\
\text { mim. }\end{array}$ \\
\hline \multicolumn{2}{|c|}{ Constructo Influência Social } \\
\hline Itens originais da UTAUT & Itens adaptados a essa pesquisa: \\
\hline SN1: People who influence my behavior & $\begin{array}{l}\text { IS1: A publicidade em mídias que se refere à } \\
\text { tecnologia me incentiva a usar o tablet no }\end{array}$ \\
\hline
\end{tabular}




\begin{tabular}{|c|c|}
\hline think that i should use the system. & meu trabalho. \\
\hline $\begin{array}{l}\text { SN2: People who are important to me } \\
\text { think that i should use the system. }\end{array}$ & $\begin{array}{l}\text { IS2: As pessoas que são importantes para } \\
\text { mim de certo modo me incentivam a utilizar } \\
\text { o Tablet. }\end{array}$ \\
\hline $\begin{array}{l}\text { SF2: The senior management of this } \\
\text { business has been helpful in the use the } \\
\text { system. }\end{array}$ & $\begin{array}{l}\text { IS3: Utilizando o Tablet no meu trabalho, } \\
\text { meus alunos me veem como uma pessoa mais } \\
\text { atualizada. }\end{array}$ \\
\hline & $\begin{array}{l}\text { IS4: O uso do Tablet e seus recursos são uma } \\
\text { forma de me aproximar dos meus familiares e } \\
\text { amigos. }\end{array}$ \\
\hline & $\begin{array}{l}\text { IS5: O uso do Tablet e seus recursos são uma } \\
\text { forma de me aproximar dos meus alunos e } \\
\text { dos meus colegas de trabalho. }\end{array}$ \\
\hline & $\begin{array}{l}\text { IS6: A direção e os demais professores da } \\
\text { escola têm me dado suporte para utilizar o } \\
\text { Tablet. }\end{array}$ \\
\hline & $\begin{array}{l}\text { IS7: Em geral, os órgãos responsáveis } \\
\text { (EAPE, NTE) tem incentivado a utilização do } \\
\text { Tablet. }\end{array}$ \\
\hline \multicolumn{2}{|c|}{ Constructo Condições Facilitadoras } \\
\hline Itens originais da UTAUT & Itens adaptados a essa pesquisa: \\
\hline $\begin{array}{l}\text { PBC2: I have the resources necessary to } \\
\text { use the system. }\end{array}$ & $\begin{array}{l}\text { CF1: Eu tenho os recursos necessários para } \\
\text { utilizar o Tablet como ferramenta } \\
\text { pedagógica. }\end{array}$ \\
\hline $\begin{array}{l}\text { PBC3: I have the knowledge necessary to } \\
\text { use the system. }\end{array}$ & $\begin{array}{l}\text { CF2: Eu tenho o conhecimento necessário } \\
\text { para utilizar o Tablet. }\end{array}$ \\
\hline $\begin{array}{l}\text { PBC5: The system is not compatible with } \\
\text { other systems I use. }\end{array}$ & $\begin{array}{l}\text { CF3: O Tablet é compatível com outros } \\
\text { recursos tecnológicos, tais como } \\
\text { computadores ou algum aplicativo que eu } \\
\text { utilizo. }\end{array}$ \\
\hline $\begin{array}{l}\text { FC3: A specific person (or group) is } \\
\text { available for assistance with system } \\
\text { difficulties. }\end{array}$ & $\begin{array}{l}\text { CF4: Uma pessoa ou grupo está disponível } \\
\text { para ajudar quando eu tiver dificuldades com } \\
\text { o Tablet. }\end{array}$ \\
\hline
\end{tabular}


Constructo Intenção de Uso

Itens originais da UTAUT

BI1: I intend to use the system in the next $<$ n $>$ months.

BI2: I predict I would use the system in the next $<$ n $>$ months.

BI3: I plan to use the system in the next $<$ n $>$ months.

\section{Itens adaptados a essa pesquisa:}

IU1: Eu planejo utilizar o Tablet nos próximos meses.

IU2: Sempre que possível, eu irei continuar utilizando outros recursos conhecidos, tais como, o computador.

IU3: Tenho a intenção de tirar o máximo proveito do Tablet em meu trabalho.

IU4: Eu pretendo descobrir novas formas de usar o tablet em meu trabalho.

IU5: O Tablet é sempre minha primeira escolha dentre as tecnologias disponíveis na minha escola e no meu trabalho.

IU6: Eu pretendo integrar o Tablet à minha prática pedagógica.

IU7: Quando necessário, ajustarei a forma do Tablet à minha forma de ensinoaprendizagem. 


\title{
APÊNDICE C - Questionário - Versão Final
}

Para melhor visualização o questionário encontra-se disponível em:

https://docs.google.com/forms/d/1G3QKq5IabFp071zY0Ds8sEJtABoFHJ7tRaKNcFQ

$\underline{\mathrm{PToE} / \text { viewform }}$

\section{Questionário: Tablet como Ferramenta Pedagógica}

\author{
Olá caro(a) professor(a),
}

Esse questionário faz parte da pesquisa de mestrado: PERCEPÇÕES DOS PROFESSORES DA REDE PÚBLICA SOBRE O TABLET EDUCACIONAL, da Universidade de Brasília que conforme o título, visa analisar as percepções e a receptividade do professor ao Tablet Educacional.

Por isso, sua opinião sobre o Tablet e as possibilidades educacionais advindas dele é de suma importância para o desenvolvimento e aperfeiçoamento dessa pesquisa.

Espero contar com sua valiosa colaboração, respondendo a esse questionário, com a certeza do seu olhar sobre esse contexto!!!

O questionário está distribuído em seções. Em cada seção será apresentada assertivas. Para cada assertiva, você deverá marcar apenas um item numa escala demonstrando o seu grau de concordância ou não com a proposição mencionada.

Lembrando que a qualquer momento você pode cancelar a pesquisa. E ainda, sua identificação é confidencial e sigilosa.

Então, vamos ao questionário?!

Desde já, OBRIGADA!

Pesquisadora Adriana Moura

*Obrigatório

\section{$1^{a}$ Seção}

A decisão quanto a utilizar ou não o Tablet em meu trabalho cabe exclusivamente a mim.. *

\begin{tabular}{|c|c|c|c|c|c|c|c|c|}
\hline & 1 & 2 & 3 & 4 & 5 & 6 & 7 & \\
\hline Discordo inteiramente & $C$ & $C$ & $C$ & $C$ & 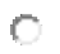 & $\mathrm{C}$ & $C$ & Concordo inteiramente \\
\hline
\end{tabular}

A SEEDF/MEC exige que eu utilize o Tablet em meu trabalho. *

$\begin{array}{lllllll}1 & 2 & 3 & 4 & 5 & 6 & 7\end{array}$

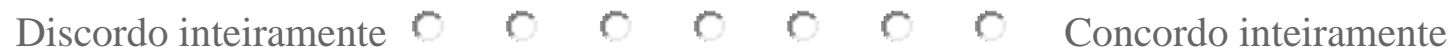

O uso do Tablet é relevante para o meu trabalho. * 


\begin{tabular}{|c|c|c|c|c|c|c|c|}
\hline 1 & 2 & 3 & 4 & 5 & 6 & 7 & \\
\hline Discordo inteiramente $\mathrm{C}$ & $\mathrm{C}$ & 0 & 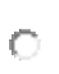 & 0 & $\mathrm{C}$ & 0 & Concordo inteiramente \\
\hline
\end{tabular}

\section{$2^{\mathrm{a}}$ Seção}

Eu acho que o Tablet é útil em meu trabalho. *

Exemplos práticos: na minha comunicação e interação entre alunos e demais pessoas do trabalho; na busca de conteúdos, na execução de tarefas de edição e outros recursos.

\begin{tabular}{llllllllll} 
& 1 & 2 & 3 & 4 & 5 & 6 & 7 & \\
\hline Discordo inteiramente & 0 & 0 & 0 & 0 & 0 & 0 & $\bigcirc$ & Concordo inteiramente
\end{tabular}

O uso do Tablet me permite poupar tempo em minhas tarefas. *

$\begin{array}{lllllll}1 & 2 & 3 & 4 & 5 & 6 & 7\end{array}$

Discordo inteiramente $\bigcirc \quad C \quad C \quad C \quad C$ Concordo inteiramente

Utilizando o Tablet, tenho mais chances de inovar o processo de ensino-aprendizagem em minhas aulas. *

$\begin{array}{lllllll}1 & 2 & 3 & 4 & 5 & 6 & 7\end{array}$

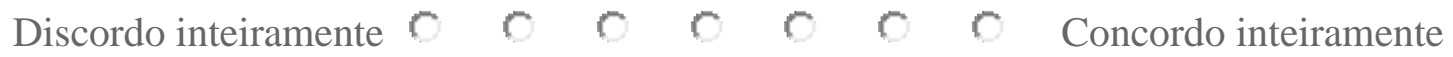

O uso do Tablet melhora meu desempenho no trabalho. *

$\begin{array}{lllllll}1 & 2 & 3 & 4 & 5 & 6 & 7\end{array}$

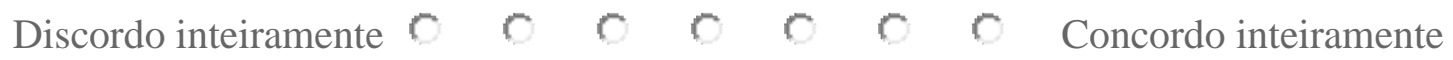

\section{$3^{\mathrm{a}}$ Seção}

A utilização dos aplicativos no Tablet é simples e fácil de entender. *

$\begin{array}{lllllll}1 & 2 & 3 & 4 & 5 & 6 & 7\end{array}$

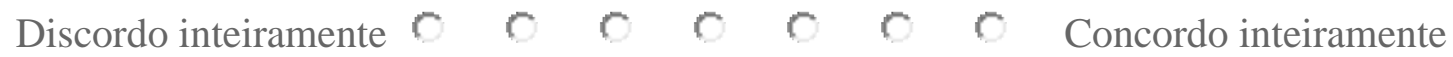
É fácil para mim me tornar um usuário habilidoso do Tablet. *

$\begin{array}{lllllll}1 & 2 & 3 & 4 & 5 & 6 & 7\end{array}$

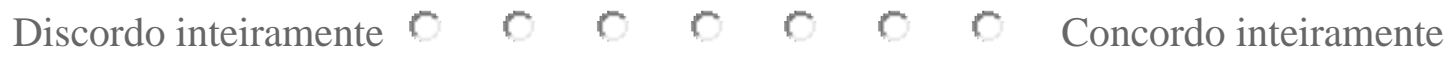
Aprender a utilizar o Tablet é fácil para mim. *

$\begin{array}{lllllll}1 & 2 & 3 & 4 & 5 & 6 & 7\end{array}$

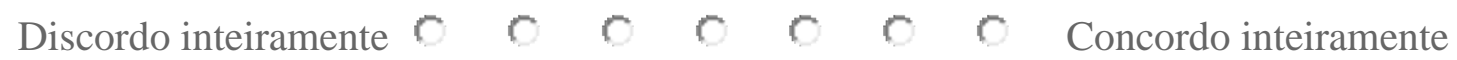




\begin{tabular}{|c|c|c|c|c|c|c|c|}
\hline 1 & 2 & 3 & 4 & 5 & 6 & 7 & \\
\hline Discordo inteiramente $\mathrm{C}$ & $\mathrm{C}$ & 0 & 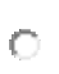 & 0 & $\mathrm{C}$ & 0 & Concordo inteiramente \\
\hline
\end{tabular}

\section{$4^{\mathrm{a}}$ Seção}

A publicidade em mídias que refere-se a tecnologias me incentiva a usar o tablet no meu trabalho*

$\begin{array}{lllllll}1 & 2 & 3 & 4 & 5 & 6 & 7\end{array}$

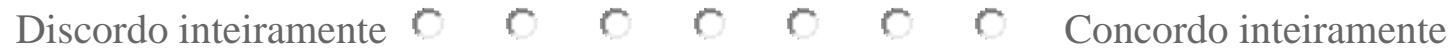

As pessoas que são importantes para mim de certo modo me incentivam a utilizar o Tablet. *

$\begin{array}{lllllll}1 & 2 & 3 & 4 & 5 & 6 & 7\end{array}$

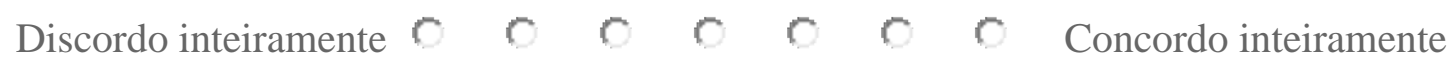

Utilizando o Tablet no meu trabalho, meus alunos me veem como uma pessoa mais atualizada. *

\begin{tabular}{lllllll}
1 & 2 & 3 & 4 & 5 & 6 & 7 \\
\hline
\end{tabular}

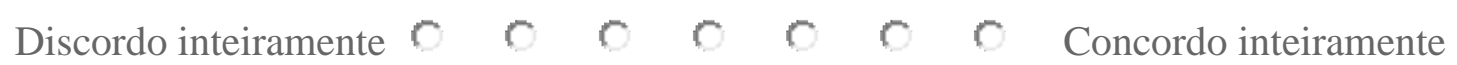

O uso do Tablet e seus recursos são uma forma de me aproximar dos meus familiares e amigos. *

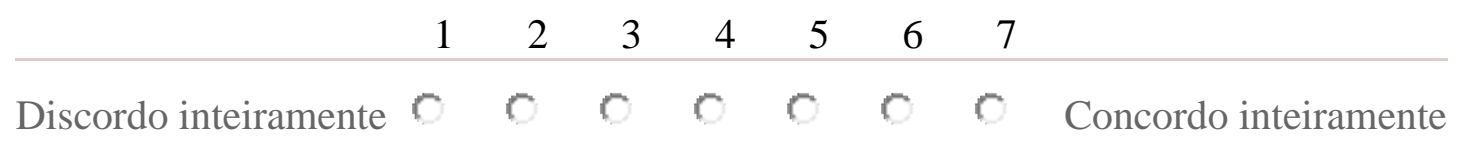

O uso do Tablet e seus recursos são uma forma de me aproximar dos meus alunos e dos meus colegas de trabalho. *

\begin{tabular}{lcccccccl}
1 & 2 & 3 & 4 & 5 & 6 & 7 & \\
\hline Discordo inteiramente & 0 & 0 & 0 & 0 & 0 & 0 & 0 & Concordo inteiramente
\end{tabular}

A direção e os demais professores da escola têm me dado suporte para utilizar o Tablet. *

$\begin{array}{lllllll}1 & 2 & 3 & 4 & 5 & 6 & 7\end{array}$

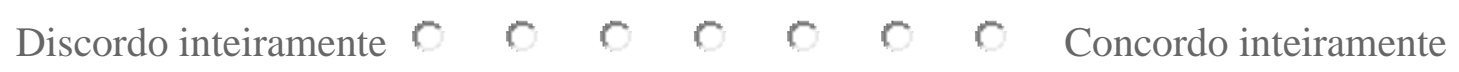

Em geral, os órgãos responsáveis (EAPE, NTE) tem incentivado a utilização do Tablet. *

$\begin{array}{lllllll}1 & 2 & 3 & 4 & 5 & 6 & 7\end{array}$

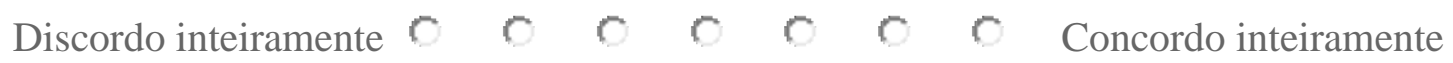




\section{$5^{\mathrm{a}}$ Seção}

Eu tenho os recursos necessários para utilizar o Tablet como ferramenta pedagógica. *

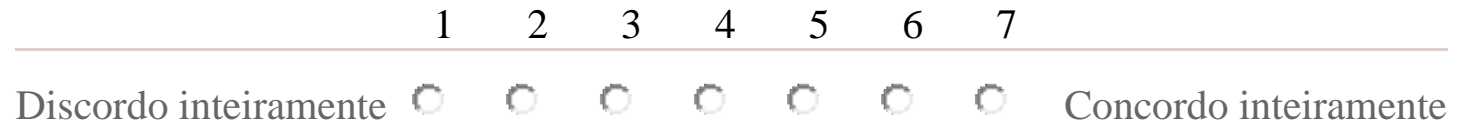

Eu tenho o conhecimento necessário para utilizar o Tablet. *

$\begin{array}{lllllll}1 & 2 & 3 & 4 & 5 & 6 & 7\end{array}$

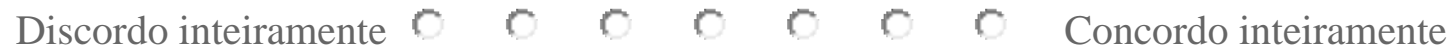

O Tablet é compatível com outros recursos tecnológicos, tais como computadores ou algum aplicativo que eu utilizo. *

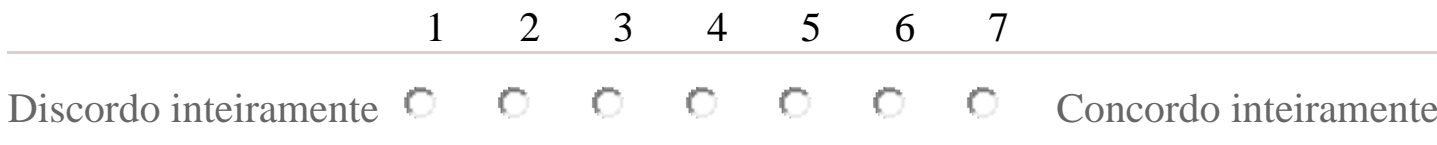

Uma pessoa ou grupo está disponível para ajudar quando eu tiver dificuldades com o Tablet. *

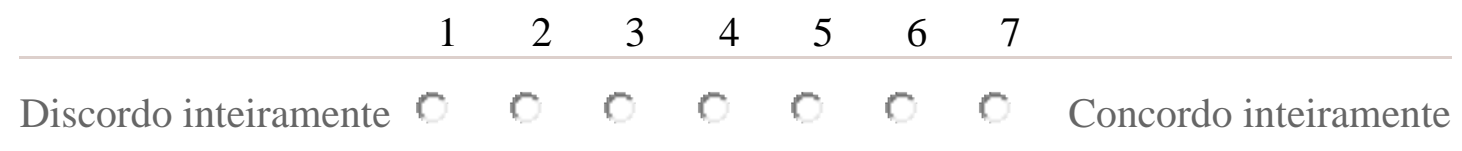

\section{$6^{\mathrm{a}}$ Seção}

Eu planejo utilizar o Tablet nos próximos meses. *

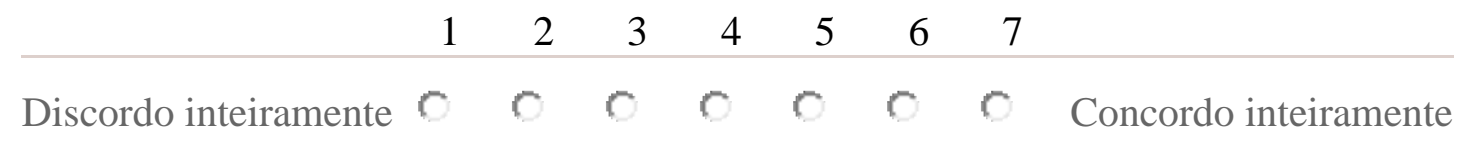

Sempre que possível, eu irei continuar utilizando outros recursos conhecidos, tais como, o computador. *

\begin{tabular}{lllllllll} 
& 1 & 2 & 3 & 4 & 5 & 6 & 7 & \\
\hline Discordo inteiramente & 0 & 0 & 0 & 0 & 0 & 0 & 0 & Concordo inteiramente
\end{tabular}

Tenho a intenção de tirar o máximo proveito do Tablet em meu trabalho. *

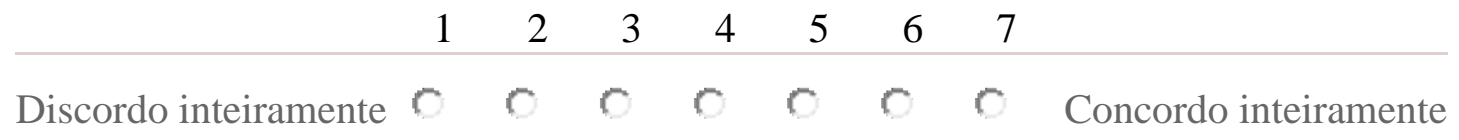

Eu pretendo descobrir novas formas de usar o Tablet em meu trabalho. * 


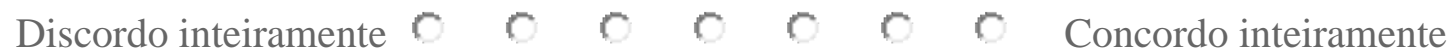

O Tablet é sempre minha primeira escolha dentre as tecnologias disponíveis na minha escola e no meu trabalho. *

\begin{tabular}{lllllll}
1 & 2 & 3 & 4 & 5 & 6 & 7 \\
\hline
\end{tabular}

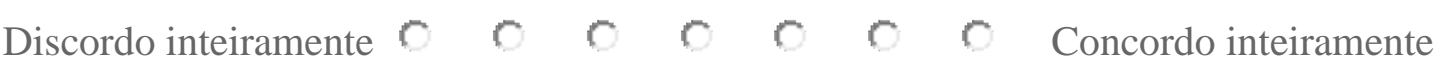

Eu pretendo integrar o Tablet à minha prática pedagógica. *

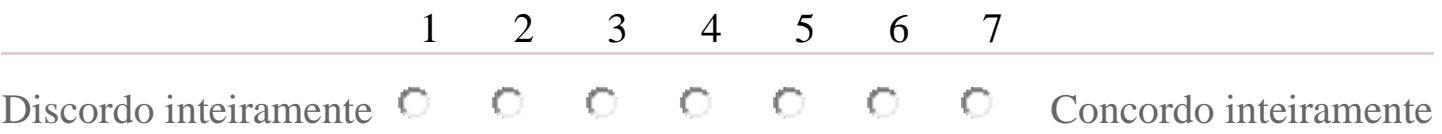

Quando necessário, ajustarei a forma do Tablet à minha forma de ensino-aprendizagem. *

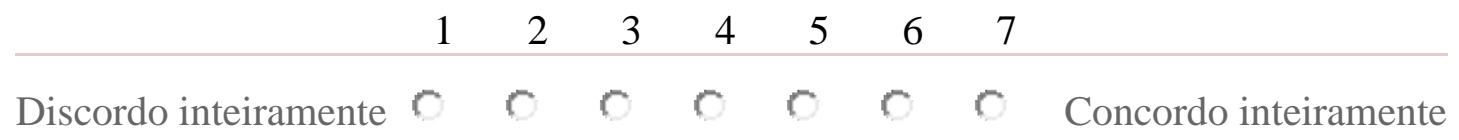

\section{$7^{\mathrm{a}}$ Seção}

Sua idade:

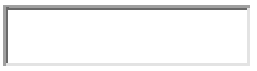

\footnotetext{
Seu gênero: *

$\circ \Gamma$ Feminino

○ Masculino
}

Tempo de serviço: *

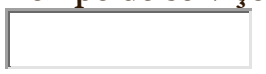

Sua formação acadêmica: *

Participou de outros cursos voltados às mídias? Marque suas respostas. *
- Mídia em Educação
○ TV Escola
- $\square$ Curso Proinfo / NTE
○ Nenhum
○ Г Outro: 
Qual o seu grau de familiaridade com o recurso tecnológico- Tablet e seus aplicativos: *

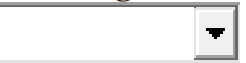

Marque as tecnologias disponíveis em sua escola para uso pedagógico: *

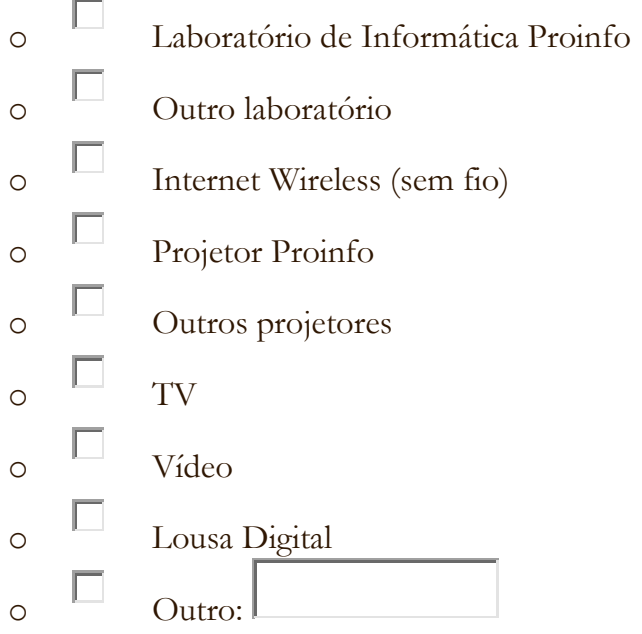

\section{Última Seção}

Falta pouco para finalizarmos o questionário. Questão Final!!!! Novamente obrigada por sua contribuição! Através dela poderei compreender as concepções de você, professor, acerca desse tema. Um grande abraço, Pesquisadora Adriana Moura

O que lhe motivou a fazer parte do Projeto Educação Digital do MEC, este que oferece o Tablet no âmbito educacional? *

$\overline{1}$

Sobre o curso: Tablet como ferramenta pedagógica da EAPE: Você conseguiu concluí-lo? * Sim ou Não, fale sobre os fatores que influenciaram sua atitude. É importante para entender o todo contexto.

Que tal você deixar uma sugestão, crítica, informação ou algo que gostaria de dizer e não teve oportunidade neste questionário?

Esse espaço é todo seu. 


\section{APÊNDICE D- Termo de consentimento Livre e Esclarecido da Entrevista Semiestruturada}

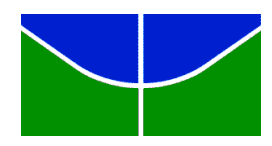

Universidade de Brasília - UNB

Faculdade de Educação- FE

\section{$\underline{\text { Termo de consentimento Livre e Esclarecido }}$}

Diante dos seguintes esclarecimentos:

"Você está sendo convidado a participar da pesquisa: Percepções dos professores da rede pública sobre o tablet educacional: Um estudo da receptividade no DF. O objetivo desta pesquisa é desenvolver uma detalhada análise da receptividade dos professores quanto ao tablet educacional, proposto no Projeto Educação Digital. Para isso, será necessária sua participação nesta entrevista semiestruturada, com duração de 1 hora, no qual serão feitas 14 perguntas, que poderão conduzir a outras durante a entrevista. Ela será totalmente gravada para facilitar o registro da pesquisadora. Sua participação é voluntária, não havendo penalidades em sua desistência. Os dados coletados serão tratados de forma sigilosa, protegendo sua identidade e os resultados serão disponibilizados a toda comunidade acadêmica e a sua localidade. Todos os dados serão armazenados pela pesquisadora, vinculada a Faculdade de Educação. Este termo se encontra redigido em duas vias de igual conteúdo e teor, sendo uma para o participante e outro para a pesquisadora."

Assim, declaro minha ciência sobre os procedimentos desta pesquisa e minha condição voluntária de participante.

Nome do participante (favor utilizar letra de forma):

Assinatura do participante:

Nome da pesquisadora responsável: Adriana Alves de Moura

Currículo lates: http://lattes.cnpq.br/3401815635518303

Assinatura da pesquisadora: 


\section{APÊNDICE E - Protocolo da Entrevista Semiestruturada}

\section{Entrevistado:}

Entrevistador:

Data:

1. Dando início a nossa entrevista reportemos a entrega do tablet a você, professor. Ao recebê-lo você comparou o tablet educacional com outros ofertados no mercado? Observou alguma diferença? O que lhe chama mais atenção?

2. Isso (fato mencionado pelo professor) pode ter influenciado a sua recepção ao tablet?

3. Você conhece algum caso que influenciou?

4. Você acha natural que professores tenham dúvidas quanto a relevância desse tablet ao seu trabalho? E fora desse ambiente?

5. Em sua opinião, pode-se dizer que o tablet melhora o seu desempenho do professor no trabalho? E fora desse ambiente?

5.1. Resposta positiva: Pode citar alguns exemplos?

5.2. Resposta negativa: Por quê?

5.2.1. Falta de conhecimento dos recursos?

5.2.2. Devido a falta de recursos?

5.2.3. Desconhece experiências exitosas?

5.3. No caso do tablet ser compatível com outros recursos tecnológicos que você conhece, até que ponto isso facilita o seu desempenho/performance?

6. Se o curso de formação não fosse obrigatório, você o faria? Por quê?

6.1. Mesmo sabendo da possibilidade de recebimento por seus alunos?

7. Você ver diferenças nas condições de uso durante e após as formações?

8. Como você se sente com a possibilidade de usar o tablet na sua sala de aula?

9. Você considera a direção e seus colegas de trabalho pessoas facilitadoras para utilizar o tablet no âmbito escolar?

10. E a EAPE e o NTE (Núcleo de Tecnologia Educacional), eles incentivam o uso do tablet? Também podem ser consideradas facilitadoras neste processo? 
11. Você acha que o tablet pode ser um concorrente em relação às explicações do professor, atraindo ou tirando a atenção dos alunos?

12. Quais recursos ou condições você considera ideais para a utilização do tablet como ferramenta pedagógica?

12.1. Esse contexto existe hoje na SEDF?

13. É possível adaptar o tablet ao seu modo de ensinar? Como? Pode citar algo prático?

14. Caro professor, esse momento está aberto para o que você gostaria ter falado e não teve oportunidade.

Obrigada pela atenção!

Adriana Moura

Mestranda da FE-UNB 